UNIVERSIDADE DE BRASÍLIA

INSTITUTO DE CIÊNCIAS BIOLÓGICAS

DEPARTAMENTO DE BIOLOGIA CELULAR

PROGRAMA DE PÓS-GRADUAÇÃO EM BIOLOGIA MOLECULAR

ESTUDO DO TRANSCRITOMA GLOBAL DO FUNGO ASPERGILLUS TERREUS QUANDO CULTIVADO EM RESÍDUOS AGROINDUSTRIAIS

CAMILA LOULY CORRÊA

Brasília, Fevereiro de 2016. 


\section{ESTUDO DO TRANSCRITOMA GLOBAL DO FUNGO ASPERGILLUS TERREUS QUANDO CULTIVADO EM RESÍDUOS AGROINDUSTRIAIS}

Trabalho apresentado à Universidade de Brasília como requisito parcial para qualificação de tese de doutorado em Biologia Molecular pelo Programa de PósGraduação em Biologia Molecular

\section{Orientador}

Prof. Dr. Robert Neil Gerard Miller

Brasília, Fevereiro de 2016. 


\title{
ESTUDO DO TRANSCRITOMA GLOBAL DO FUNGO ASPERGILLUS TERREUS QUANDO CULTIVADO EM RESÍDUOS AGROINDUSTRIAIS
}

\author{
CAMILA LOULY CORRÊA
}

\author{
Banca Examinoradora \\ Prof. Dr. Edivaldo Ximenes Ferreira Filho \\ Examinador interno (UnB -Departamento de Biologia Celular) \\ Profa Dra. Eliane Ferreira Noronha \\ Examinador interno (UnB - Departamento de Biologia Celular) \\ Dra. Leia Cecilia de Lima Favaro \\ Examinador Externo (Embrapa Agroenergia) \\ Dra. Natalia Florencio Martins \\ Examinador Externo (Embrapa Cenargem) \\ Dr. Gabriel Sérgio Costa Alves \\ Examinador Suplente (UNB - Departamento de |Biologia Celular) \\ Prof. Dr. Robert Neil Gerard Miller \\ Orientador
}




\section{AGRADECIMENTOS}

À Deus por estar sempre presente na minha vida, me dando força para superar as dificuldades;

Ao meu esposo Saulo pelo companheirismo, amor e paciência e é claro pela sua presença em minha vida;

À minha família que me ensinou lutar pelos meus sonhos e que o conhecimento é a única coisa importante nas nossas vidas, em especial minha mãe Edna e meu pai Celso;

Ao meu orientador Robert Miller pelo sim, pela paciência, sabedoria e compartilhamento de experiência profissional e grandes ensinamentos;

À amiga Gláucia Midorikawa, pela sua presença, dedicação e apoio em todos os momentos desta longa caminhada, muito obrigada!;

À minha prima Priscila Louly, por toda ajuda e paciência durante este momento da minha vida;

Aos amigos do laboratório Planta x Praga e Enzimologia;

Ao Prof.Dr. Edivaldo Ximenes pela ajuda, disponibilidade da estirpe A. terreus, equipamentos e reagentes utilizados neste trabalho;

À Prof. Dra. Eliane Noronha por compartilhar conhecimento e parceria no meu trabalho;

À Universidade de Brasília (UNB), aos professores e funcionários do Programa de PósGraduação em Biologia Molecular que me ajudaram e tornaram possível a realização deste curso;

À Coordenação de Aperfeiçoamento de Pessoal de Nível Superior (CAPES), ao Conselho Nacioal de Desenvolvimento Científico e Tecnológico $(\mathrm{CNPq})$ e à Fundação de Apoio a Pesquisa do Distrito Federal (FAP-DF) pelo apoio financeiro, tornando possível a realização desse trabalho; 


\section{Sumário}

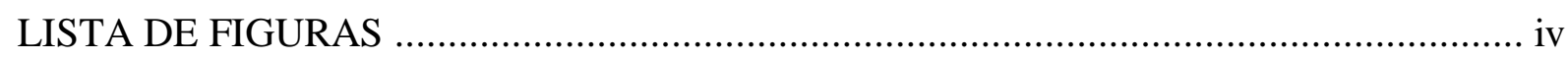

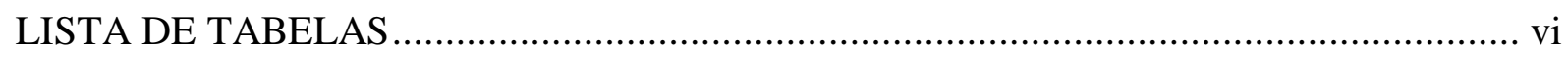

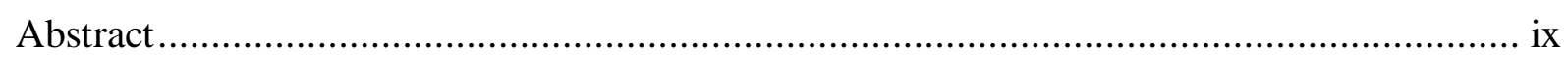

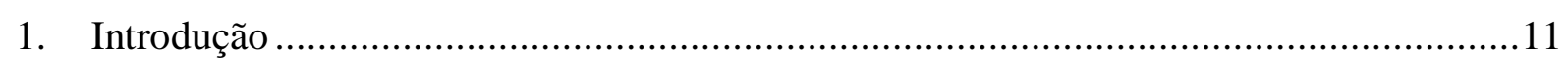

1.1 A importância dos resíduos agroindustriais na biotecnologia. .............................11

1.2 Importância econômica da produção de cana-de-açúcar, algodão e soja no Brasil........15

1.3- Deconstrução da biomassa vegetal por fungos filamentosos. .................................. 18

1.4- A produção de enzimas microbianas. ...............................................................24

1.5- A importância do estudo do transcritoma em fungos filamentosos. ...........................27

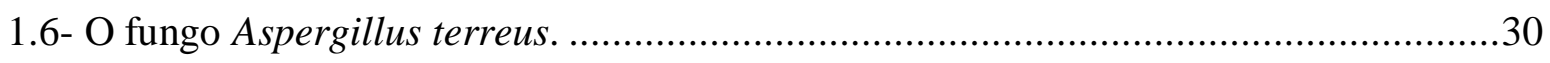

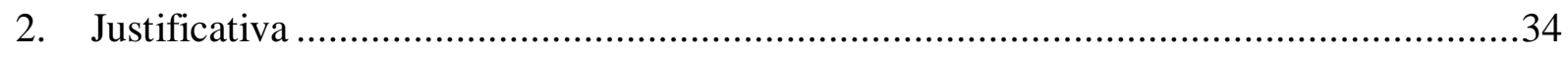

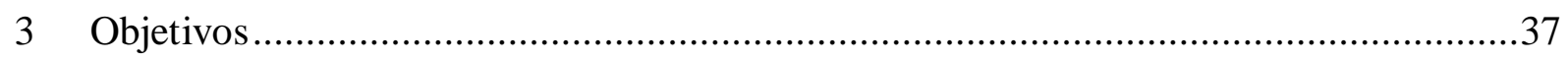

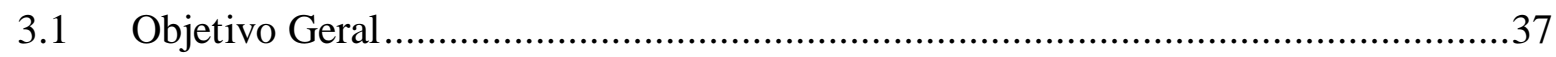

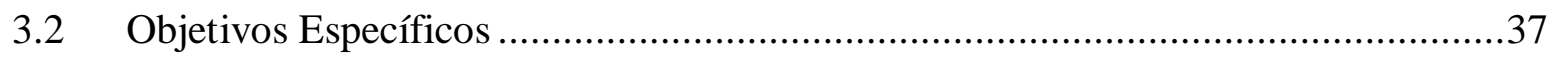

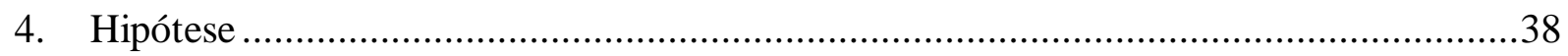

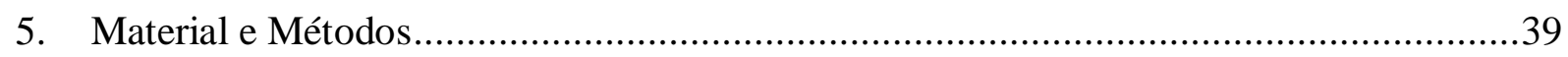

5.1 Origem e Manutenção do Fungo Aspergillus terreus. .............................................40

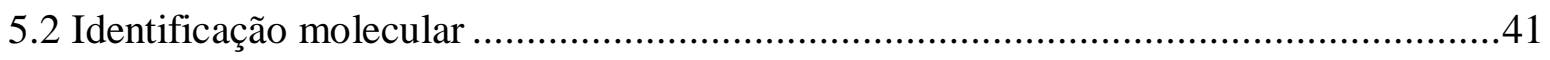

5.3 Avaliação da produção de holocelulases em A. terreus BLU24 .................................43

5.3.1 Determinação da Atividade Enzimática ........................................................43

5.4 Análise da colonização fúngica nos resíduos bagaço de cana e casca do grão de soja por meio de microscopia eletrônica de varredura (MEV) ...............................................44

5.5 Análise do transcritoma de A. terreus BLU24 ...................................................45 
5.5.2 Sequenciamento Illumina HiSeq2500.........................................................48

5.5.3Mapeamento dos reads e identificação dos transcritos .........................................49

5.5.4 Análise quantitativa da expressão gênica......................................................49

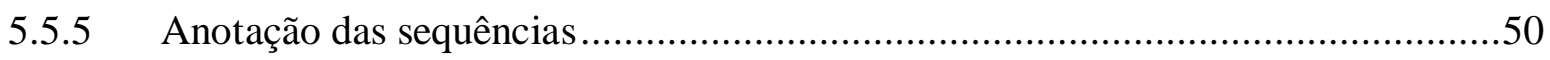

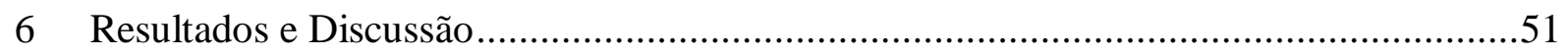

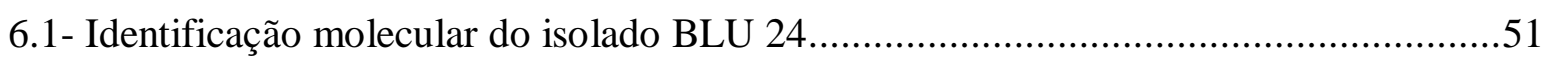

6.2- Avaliação da produção de holocelulases pelo fungo A. terreus .................................52

6.3- Análise da colonização do fungo A. terreus cultivado nos resíduos: bagaço de cana de açúcar e casca do grão de soja (pré-tratados) por meio de microscopia eletrônica de

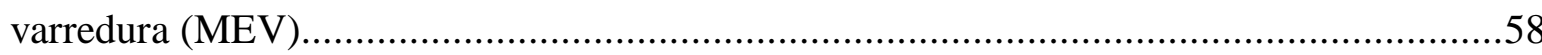

6.4 Análises dos dados do transcritoma do fungo A. terreus cultivado em resíduos agroindustriais.

6.4.1- Extração de RNA total 61

6.4.2- Construção da biblioteca de cDNA e Sequenciamento Illumina HiSeq2500. 64

6.4.3 Análise dos genes expressos por biblioteca de cDNA

6.4.4 Caracterização de ontologias dos genes (GO) de A. terreus BLU24 cultivado sob diferentes tratamentos

6.4.5 Análises de superexpressão e subexpressão de genes de A. terreus classificados dentro da família: CAzy, fatores de transcrição, oxidoredutases e permeases. .79

6.4.6 Análise dos dez genes diferencialmente expressos em bagaço de cana de açúcar e casca do grão da soja ("Top 10").

6.4.7 Análises dos genes que expressam enzimas envolvidas na degradação da parede celular vegetal do A. terreus BLU24 quando cultivado em resíduos agroindustriais.

7 Conclusão. .97

8 Perspectivas. .99

9 Referências Bibliográficas

10 Anexos 108 


\section{LISTA DE FIGURAS}

Figura 1: Diagrama da correlação entre as biomassas fósseis e renováveis

Figura 2: Série histórica de geração de resíduos lignocelulósicos no Brasil

Figura 3: Estrutura da parede celular vegetal, evidenciando celulose, hemicelulose e pectina

Figura 4: Foto do Fungo Aspergillus terreus cultivado em meio de cultura sólido

Figura 5: Microscopia eletrônica de varredura do A. terreus .....

Figura 6: Delineamento experimental

Figura 7: Diagrama mostrando o delineamento experimental

Figura 8: Iniciadores utilizados para amplificar partes ou totalidade da região ITS

Figura 9: Perfil e produção de holocelulases pelo isolado BLU 24 cultivado em meio suplementado com extrato de levedura $1 \%$ .53

Figura 10: Microscopia eletrônica de varredura da colonização do fungo A. terreus cultivado em resíduos agroindustriais.

Figura 11: Comparação da integridade das amostras de RNA total do A. terreus BLU24 ......61

Figura 12: Avaliação da integridade do RNA total de A. terreus pelo Bioanalyzer (Agilent Technologies).

Figura 13: Heatmap dos genes expressos de A. terreus quando cultivado em bagaço de cana de açúcar, casca do grão da soja e glicose

Figura 14: Distribuição dos Processos Biológicos dos dados do transcritoma do A. terreus BLU24

Figura 15: Distribuição dos Componentes Celulares dos dados do transcritoma do A. terreus BLU24

Figura 16: Distribuição das Funções Moleculares dos dados do transcritoma do A. terreus BLU24 . .73

Figura 17: Distribuição diferencial de termos GO no tratamento B36xG36 (bagaço comparado com glicose no tempo de 36 horas).

Figura 18: Distribuição diferencial de termos GO no tratamento B48xG48 (bagaço comparado com glicose no tempo de 48 horas). .76 
Figura 19: Distribuição diferencial de termos GO no tratamento S36xG36 (soja comparado

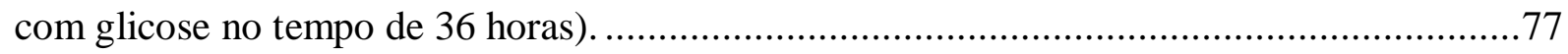

Figura 20: Distribuição diferencial de termos GO no tratamento S48xG48 (soja comparado

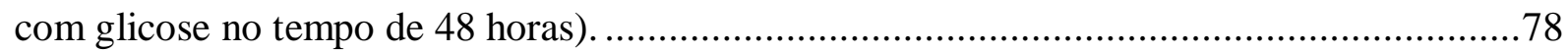

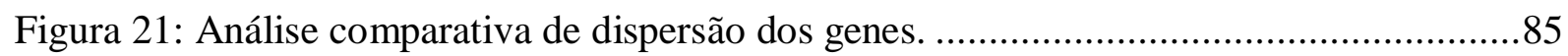

Figura 22. Genes classificados na análise do transcritoma de A. terreus cultivado em casca do grão da soja, de acordo com a abundância de enzimas classificadas como CAZy .93

Figura 23: Diagrama de Venn mostrando a distribuição dos genes CAZY nos tratamentos bagaço de cana de açúcar e casca de soja comparado com a glicose nos tempos de 36 e 48 horas. .94 


\section{LISTA DE TABELAS}

Tabela 1: Divisão das subfamílias e atividades da classe AA. 22

Tabela 2: Delineamento experimental dos tratamentos utilizados para a análise do

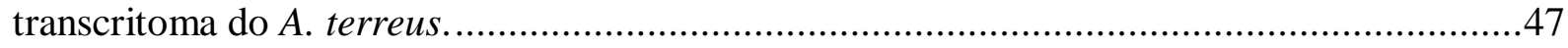

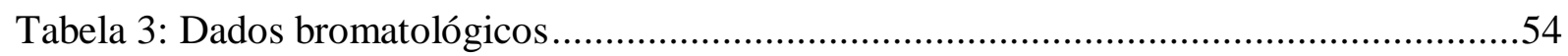

Tabela 4: Resumo dos dados estatísticos do sequenciamento das bibliotecas de cDNA de A. terreus cultivadas em diferentes fontes de carbono (bagaço de cana de açúcar, casca do grão da soja e glicose).

Tabela: 5: Fold change e anotação dos 10 primeiros genes diferencialmente expressos nos diferentes tratamentos (“Top 10").....

Tabela 6: A tabela mostra os genes codificados relacionados com a degradação da parede celular de plantas que ocorreram exclusivamente em cada tratamento (casca do grão de soja 36 e 48 horas e bagaço de cana 36 e 48 horas) .95 


\section{RESUMO}

Aspergillus terreus é um fungo filamentoso que produz numerosas enzimas com uma vasta gama de aplicações biotecnológicas. Este estudo tem como objetivo caracterizar a produção das enzimas lignocelulolíticas de A. terreus, estirpe BLU24, crescido em meios de cultura contendo resíduos agroindustriais (bagaço de cana de açúcar, casca do grão de soja e piolho de algodão sujo) e analisar a expressão diferencial desses genes em resposta a essas fontes de carbono. A crescente utilização de resíduos como bagaço de mandioca, bagaço de cana de açúcar, polpa de beterraba, polpa de maçã, farelo de trigo, etc evidencia que diferentes áreas da indústria utilizam estes resíduos como matéria prima para a produção de etanol, enzimas, cogumelos, ração animal, ácidos orgânicos, aminoácidos, metabólitos secundários, produtos farmacêuticos. A. terreus BLU24 foi crescido à $28^{\circ} \mathrm{C}$ sob agitação (120rpm) ao longo de um período de dez dias. O secretoma foi analisado de acordo com as atividades enzimáticas de xilanase, endoglucanase, mananase, pectinase e FPase identificadas de acordo com o método DNS. Dentre todas as atividades estudadas a que foi mais expressiva foi à atividade relacionada com proteínas do tipo xilanases. A atividade de xilanase após cultivo no meio contendo piolho de algodão sujo atingiu um valor máximo de 0,935 UI.mL $^{-1}$ no sexto dia de cultivo, já no meio com bagaço de cana de açúcar este valor foi de 1,017 UI.mL ${ }^{-1}$ no sétimo dia e no meio contendo casca do grão da soja a atividade máxima foi também no sétimo dia, atingindo um valor de 1,019 UI.mL ${ }^{-1}$. A maior atividade de CMCase foi no bagaço de cana de açúcar que atingiu um valor máximo no quarto dia de cultivo $(0,275$ UI.mL ${ }^{-1}$ ). Já a maior atividade de pectinase foi no substrato casca do grão da soja no terceiro dia de cultivo $\left(0,494\right.$ UI. $\left.\mathrm{mL}^{-1}\right)$ e a maior atividade de FPase foi também na casca do grão da soja no sétimo dia de cultivo $\left(0,494\right.$ UI. $\left.\mathrm{mL}^{-1}\right)$. O preparo das bibliotecas de cDNA de mRNA do fungo A. terreus foi conduzida utilizando o kit RNA TruSeq Kit v2 (® Illumina, Inc.). A. terreus também mostrou um desempenho significativo como produtor de holocellulases. As bibliotecas de cDNA sequenciadas produziu uma média total de 2,7 GB, com cerca de 27 milhões de leituras. Aproximadamente $81 \%$ das leituras exibiram uma boa qualidade $(\mathrm{Q}>=$ 30). A caracterização deste transcritoma oferece a descoberta de genes promissores para aplicação em diferentes áreas da indústria biotecnológica. As análises de RNA-seq do isolado A. terreus BLU24 cultivado em bagaço de cana de açúcar identificaram um total de 102 genes CAZy, já em casca do grão da soja o total de genes CAZy foi 159 (padj <0.01). Tanto no tratamento contendo bagaço de cana de açúcar quanto no tratamento contendo casca do grão 
da soja comparado a glicose, as famílias CAZy mais abundantes foram a GH3 e GH43. Análises das famílias glicosil hidrolases revelou regulação positiva de 6 genes que codificam proteínas da família GH5, 7 genes da família GH43 e 8 genes da família GH3 no tratamento com bagaço de cana de açúcar contra a glicose. Similarmente no tratamento com casca do grão da soja contra a glicose foram relatados 7 genes que codificam proteínas da família GH5, 6 genes da família GH10, 11 genes da família GH3 e 12 genes da família GH43 (p<0,01). Os genes que codificam proteínas relacionadas com a degradação da biomassa são expressos nas duas fontes de carbono estudadas, porém alguns desses genes com expressão diferencial ocorreram apenas no bagaço de cana de açúcar ou apenas na casca do grão da soja nos tempos de 36 e 48 horas. O estudo do transcritoma global do fungo A. terreus BLU24 identificou uma grande quantidade de genes que codificam enzimas utilizadas na degradação da parede celular vegetal e também fatores de transcrição que são importantes neste processo. A. terreus é conhecido por ser um bom produtor de enzimas envolvidas na degradação da biomassa vegetal e uma característica importante deste fungo é o fato dele ser termofílico e com isso poder produzir enzimas termotolerantes com diferentes aplicações na indústria têxtil, biocombustível, papel, alimento e etc. 


\begin{abstract}
Aspergillus terreus is a filamentous fungus that produces numerous enzymes with a wide range of biotechnological applications. The aim of this study was to characterize the production of lignocellulolytic enzymes in A. terreus strain BLU 24 following culture in growth media containing agro-industrial residues (sugar cane bagasse, soy bean hulls and cotton louse) and analyze differential gene expression in response to carbon source. Given the abundance of agricultural waste materials such as cassava bagasse, sugar cane bagasse, sugar beet pulp, apple pulp and wheat bran, numerous applications are under development using such residues as raw material. These include utilization in production of ethanol, industrial enzymes, edible mushrooms, animal feed, organic acids, amino acids, secondary metabolites, and pharmaceutical products. A. terreus BLU 24 was grown at $28^{\circ} \mathrm{C}$ under agitation (120rpm) over a period of ten days. The secretome was analyzed for xylanase, endoglucanase, mannanase, pectinase and FPase enzyme activities, according to the DNS method. Among all the activities studied, most significant enzyme activities were related to xylanase, with activity reaching a maximum of 0.935 UI.mL-1 after six days incubation in minimal growth medium plus cotton louse as sole carbon source, 1.017 UI.mL-1 after seven days incubation with sugarcane bagasse as carbon source, and 1,019 UI.mL-1after seven days incubation with soybean hulls as carbon source. Most CMCase activity was observed on sugarcane bagasse, with a peak in activity by the fourth day of cultivation (0.275 UI.mL-1). Pectinase activity was higher on soybean hulls as substrate after cultivation during three days (0.494 UI.mL-1), with highest FPase activity observed on soybean hulls in seven day old cultures (0.494 IU. ml-1).Characterization of the fungal transcriptome was conducted to identify candidate genes for application in different areas of the biotechnology industry. cDNA libraries were prepared from A. terreus BLU 24 mRNA following $36 \mathrm{~h}$ and $48 \mathrm{~h}$ growth on sugarcane bagasse and soybean hull-derived carbon sources. Illumina Hiseq sequencing of cDNA libraries produced a mean total of $2.7 \mathrm{~GB}$, equaling approximately 27 million reads. A total of $81 \%$ of the reads exhibited good quality (Q> = 30). RNA-seq analysis of A. terreus BLU 24 identified a total of 102 expressed cazy genes following growth on sugarcane bagasse with 159 identified following growth on media with soybean hull carbon source (padj <0.01). For both carbon source treatments, compared to glucose, the most abundant Cazy gene families were GH3 and GH43. Analysis of the glycosyl hydrolase family revealed up-regulation of six genes
\end{abstract}


encoding GH5, seven GH43 genes and eight GH3-encoding genes following cultivation on sugarcane bagasse against glucose. Similarly, cultivation on soybean hulls against glucose revealed seven genes that encode protein family GH5, six genes encoding GH10, 11 genes encoding GH3 and 12 genes encoding the GH43 family $(\mathrm{p}<0,01)$. Genes encoding proteins related to the degradation of biomass were expressed during growth on the two carbon sources studied, with differential expression in relation to glucose occuring for different sets of genes in sugarcane bagasse and soybean hulls at each growth period of 36 and 48 hours. This global analysis of the transcriptome for the fungus A. terreus BLU 24 following cultivation on lignocellulosic carbon sources enabled identification of a number of genes encoding enzymes and transcription factors involved in the degradation of the plant cell wall. A. terreus is recognized as a promising fungal species for production of enzymes involved in the degradation of plant biomass. Given that this fungus is also able to produce thermophilic enzymes, considerable potential exists in the application of the characterized candidate genes in different applications in the textile, biofuel, paper, food and feed industries. 


\section{INTRODUÇÃO}

\subsection{A importância dos resíduos agroindustriais na biotecnologia.}

O tradicional processo industrial, além do produto de interesse, gera múltiplas saídas de outros materiais em forma de resíduos e emissões não incorporadas no produto final que, geralmente, são aceitas como efeito normal no processo de fabricação. Porém, nos últimos anos têm se intensificado o aproveitamento de resíduos, especialmente os agroindustriais tais como, polpa e folhas de café, resíduos de frutas, bagaço de mandioca, farelo de soja, bagaço de cana de açúcar, polpa de beterraba, etc. Vários processos biotecnológicos foram desenvolvidos para utilizar esses materiais na produção de álcool, enzimas, ácidos orgânicos, aminoácidos, gerando produtos de grande valor econômico. A procura de enzimas industriais, em particular de origem microbiana é cada vez maior, devido à suas aplicações em uma ampla variedade de processos.

Alguns problemas relacionados aos resíduos agroindustriais como poluição e a escassez de locais para a sua eliminação tem incentivado a utilização e a bioconversão de resíduos em um alto valor de produtos industrialmente úteis. A reciclagem de recursos está tornando válido e viável à atividade econômica e é cada vez mais mencionado como solução para problemas graves relacionados ao homem (Chapla et al, 2010). A reciclagem de resíduos agrícolas e agro-industriais vem ganhando espaço cada vez maior, não simplesmente porque os resíduos representam "matérias primas" de baixo custo, mas, principalmente, porque os efeitos da degradação ambiental decorrente de atividades industriais e urbanas estão atingindo níveis cada vez mais alarmantes. Vários projetos de reciclagem têm sido bem-sucedidos no Brasil e dentre eles destacam-se o aproveitamento de papel, plásticos, metais, óleos lubrificantes automotivos e industriais, soro de leite e bagaço de cana (Neto \& Rossi, 2000).

Os fungos desempenham um importante papel no processo de bioconservação, pois podem reduzir a quantidade de resíduos, minimizar a poluição, formar produtos de interesse às indústrias de alimentos, papel, fármacos, entre outros.

Os resíduos agrícolas são classificados em duas categorias, resíduos de colheita (ou seja, resíduos de plantas, tais como raízes, folhas, palhas, restolho, etc) e resíduos provenientes de atividades agro-industriais que são subprodutos de pós-colheita e 
processamento de alimentos, entre outros. Resíduos da colheita são um dos principais resíduos orgânicos, com uma produção anual de cerca de $74 \mathrm{Tg}$ (teragrama) de resíduos vegetais secos produzidos em todo o mundo (Kim \& Dale, 2004).

A biomassa renovável terrestre é constituída de diversos produtos de baixas e altas massas moleculares como, por exemplo, carboidratos, aminoácidos, lipídios e biopolímeros. Estas biomassas são utilizadas na alimentação e para a produção de uma variedade de combustíveis, produtos químicos e produtos energéticos. O processamento da biomassa renovável abrange métodos biológicos, térmicos e/ou transformações químicas, além de tratamento mecânico para obter combustíveis sólidos, líquidos ou gasosos ou ainda produtos químicos de maior valor agregado (Ferreira \& Rocha, 2009) (figura 1).

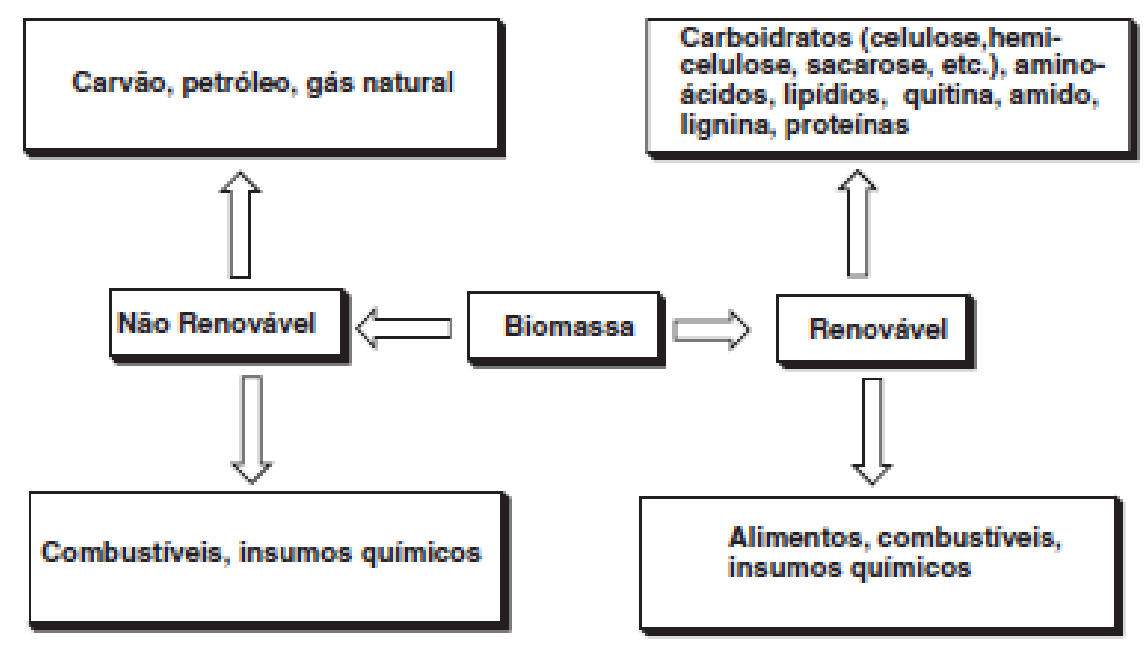

Figura 1: Diagrama da correlação entre as biomassas fósseis e renováveis (Ferreira \& Rocha, 2009).

Países de todo o mundo têm considerado e implantado políticas para o aumento da utilização de biomassa para satisfazer as suas futuras demandas energéticas a fim de atender a redução de emissão de dióxido de carbono especificado no Protocolo de Quioto e também reduzir a dependência da oferta de combustíveis fósseis (Sarkar et al., 2012). Resíduos agroindustriais são, em sua maioria, de natureza lignocelulósica (Kerem et al.,1992) e de acordo com Sermanni \& Porri (1989) a utilização de material lignocelulósico para a obtenção de compostos de alto valor econômico, por biotransformação, é um dos mais interessantes campos da pesquisa biotecnológica.

O Brasil tem sido um líder mundial em agroenergia nas últimas décadas. A oferta interna de energia no Brasil em 2010 foi de 268.754 milhões de toneladas de equivalente de 
petróleo. As fontes renováveis de energia foram responsáveis por 45,5\% deste montante, aonde $14,0 \%$ vieram de hidráulica e eletricidade, $9,7 \%$ de lenha e carvão vegetal, $17,8 \%$ a partir de produtos derivados da cana-de-açúcar e 4,0\% de outras fontes renováveis. O setor agroindustrial brasileiro produz grande quantidade de resíduos e subprodutos que, potencialmente, pode ser usado como fontes de energia. A cada ano cerca de 330 milhões de toneladas métricas (mg) de resíduos da biomassa são gerados no país. Parte destes resíduos é gerada a partir de culturas, de todos os setores da indústria, principalmente a de alimentos (Virmond et al., 2012).

As matérias-primas lignocelulósicas são as fontes renováveis mais abundantemente encontradas na natureza, sendo compreendidas, majoritariamente, pelos materiais agroindustriais, pelos resíduos urbanos e pelas madeiras de angiospermas e gimnospermas. Dentre essas, os materiais agroindustriais se destacam pelo caráter de resíduo, conferido por sua obtenção após o processamento de matérias-primas que apresentam maior valor agregado, e pela vocação natural que o Brasil possui para sua geração (Szengyel, 2000). Desta forma, a figura 2 apresenta séries históricas de geração de materiais lignocelulósicos no Brasil, com as massas representadas em base úmida. Juntos, no ano de 2007, os materiais apresentados na figura 2 somaram uma massa gerada no Brasil de 606 milhões de toneladas, das quais cerca de 105 milhões de toneladas correspondem a fração celulósica (Castro \& Jr, 2010).

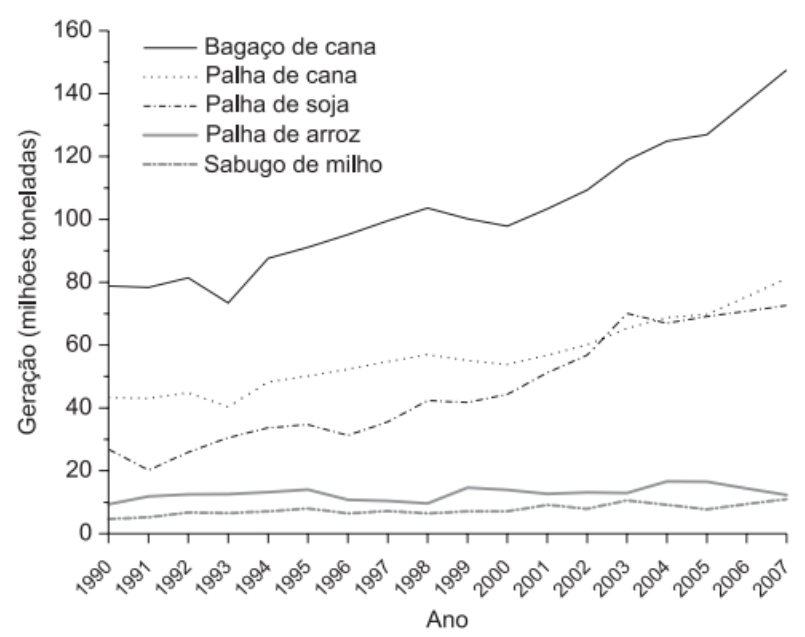

Figura 2: Série histórica de geração de resíduos lignocelulósicos no Brasil (Castro \& Jr, 2010).

Os resíduos agroindustriais vêm sendo utilizados de forma experimental, pesquisas realizadas pela Embrapa Florestas mostram aumentos significativos de produtividade com a aplicação de resíduos gerados pela indústria de papel e celulose em plantios de Eucalyptus grandis. Pesquisadores da Universidade Federal Rural do Rio de Janeiro utilizaram o estipe 
de Euterpe edulis Martius com o objetivo de avaliar o potencial desse material vegetal desprezado na colheita do palmito, como matéria-prima fibrosa, sendo uma alternativa para a produção de polpa celulósica (Andrade et al.,2000).

Enzimas queratinolíticas produzidas por fungos e bactérias tem sido frequentemente isolada de solos onde materiais queratinosos são depositados. Uma considerável quantidade de proteínas fibrosas insolúveis de penas, cabelos, unhas, chifres estão disponíveis como subprodutos do processamento agroindustrial. Essas enzimas queratinolíticas podem ter utilizações importantes na conversão biotecnológica de resíduos contendo queratina das indústrias de aves e couro, por meio do desenvolvimento de processos não poluentes. Queratinas de penas insolúveis podem ser convertidas, após a hidrólise enzimática, em alimentos para os animais, fertilizantes e filmes (Gupta and Ramnani, 2006). Além disso, aplicações dessas enzimas para fins farmacêuticos e cosméticos já foram descritas (Brandelli, 2008).

Outro exemplo do uso da biotecnologia por meio de resíduos agroindustriais é a produção de xilitol. O xilitol é um poliol com propriedades físico-química importantes para a indústria alimentícia e farmacêutica. É um composto com doçura semelhante à da sacarose, anticariogênico, tolerado por diabéticos e recomendado para pessoas obesas. Este poliol é produzido, em grande escala, por hidrogenação catalítica da xilose presente em hidrolisados lignocelulósicos, porém as soluções obtidas por este processo requerem onerosos passos de purificação para obtenção do xilitol puro. Alternativamente, pode ser produzidas por métodos biotecnológicos utilizando leveduras e/ou enzimas. Tais processos consistem na fermentação de hidrolisados hemicelulósicos de resíduos agroindustriais, e podem competir com o tradicional processo químico (Tamanini \& Hauly, 2004).

A crescente utilização de resíduos como bagaço de mandioca, bagaço de cana de açúcar, polpa de beterraba, polpa de maçã, farelo de trigo, etc evidencia que muitos processos têm sido desenvolvidos utilizando estes resíduos como matéria prima para a produção de etanol, enzimas, cogumelos, ração animal, ácidos orgânicos, aminoácidos, metabólitos secundários, produtos farmacêuticos, etc. Esta produção está relacionada a um aumento da demanda, crescimento da economia dos países, busca por processos que degradem e/ou poluem menos o meio ambiente, busca por melhorias na eficiência da produção, etc e a biotecnologia é essencial para a melhoria e sucesso desses bioprocessos.

A tendência dos estudos atuais é desenvolver processos que permitam um aproveitamento mais racional dos resíduos lignocelulósicos como o bagaço da cana por meio 
da produção biotecnológica de substâncias de interesse industrial como: etanol, xilitol, ácido succínico, ácido láctico, entre outras. Para processos que utilizem resíduos lignocelulósicos é necessária uma etapa na qual sejam liberados os glicídios constituintes das diferentes frações hemicelulósicas e celulósicas, denominada pré-tratamento ou hidrólises química e/ou enzimática, que seja economicamente viável e permita uma alta eficiência da extração dos glicídios, baixa degradação dos açúcares e diminuição na produção de inibidores (Sun \& Cheng, 2002).

\subsection{Importância econômica da produção de cana-de-açúcar, algodão e soja no Brasil}

A cana-de-açúcar foi introduzida no país em 1532 e sempre teve importância destacada na economia do país. O país não é só o maior produtor da cultura, seguido por Índia e China, como também o maior produtor de açúcar e etanol de cana de açúcar. Responsável por mais de $50 \%$ do açúcar comercializado no mundo, o país deve ter aumento na sua produção este ano em 5,0\%. Apesar de pouco mais de $50 \%$ da produção estar concentrada em São Paulo, a cultura é cultivada em todas as regiões do país. A cultura tem um papel ambiental muito importante, uma vez que o etanol, um dos subprodutos da cana-de-açúcar, é uma das melhores alternativas para reduzir a emissão de gases causadores do efeito estufa, haja vista que a sua queima como combustível reduz em $70 \%$ a emissão de $\mathrm{CO}_{2}$ na atmosfera em relação à gasolina (acessado em julho de 2015 www.conab.gov.br).

Devido a sua excepcional capacidade de produzir biomassa, a cana de açúcar será sempre importante em uma economia dependente da biomassa (Muchow et al., 1994). A produção de bioetanol a partir da cana começou no Brasil em 1920, quando o Instituto do Açúcar e do Álcool foi criado para ajudar a governar a regulação da produção da cana. Após a primeira crise do petróleo em 1973, o governo brasileiro criou o Proálcool para desenvolver novas fontes de energia a partir da cana (Martinez-Filho et al., 2006).

O principal objetivo do Proálcool era produzir etanol desidratado e uma mistura com gasolina como combustível para transporte. Ao mesmo tempo, os motores dos carros foram redesenhados, e em 1978, os primeiros carros capazes de utilizar exclusivamente o bioetanol foram produzidos. Depois de 2003, o Brasil desenvolveu o carro "flex" em que o motor é capaz de utilizar tanto o bioetanol ou a gasolina ou uma mistura dos dois em qualquer proporção (De Souza et al., 2014).

O setor de biocombustíveis brasileiro é considerado o mais eficaz no mundo (Goldemberg, 2010). Entre 1980 e 1998, a produtividade da cana no Brasil aumentou de 73 
para 90 toneladas de colmos por hectare. No Brasil, a cana é a matéria prima mais bemsucedida para bioenergia com maior eficiência de produção e uma indústria bem desenvolvida para a produção de bioetanol (Goldemberg, 2010).

Embora a agricultura canavieira e a indústria de transformação obtiveram alta eficiência, ainda é possível aumentar a produtividade da cana e a produção de bioetanol, melhorando alguns aspectos do uso da cana de açúcar. Na verdade, o sistema agrícola de cana no Brasil não atingiu o mais alto rendimento possível em comparação com outros países produtores de cana de açúcar (Waclawovsky et al., 2010).

O Brasil deverá produzir 654,6 milhões de toneladas de cana de açúcar nesta safra (2015/2016) em pouco mais de 9 milhões de hectares. A estimativa é de que a produção do país tenha um incremento de $3,1 \%$ em relação à safra passada e só não é maior porque o aumento na área plantada no país é relativamente pequeno $(0,7 \%)$ e a produtividade nos canaviais de São Paulo, maior estado produtor, se recuperam de um impacto hídrico da safra passada. A produção total de cana-de-açúcar destinada à indústria, estimada para a safra 2015/16 é de 654,6 milhões de toneladas, com acréscimo de 3,1\% (19,8 milhões de toneladas) em relação à safra 2014/15, que foi de 634,8 milhões de toneladas. Na safra 2014/15 a produção de açúcar chegou a 35,56 milhões de toneladas. Para a safra 2015/16 a expectativa é de aumento de 5\%, chegando a 37,35 milhões de toneladas. Já a produção de etanol total consolidou-se em 28,66 bilhões de litros na safra 2014/15 e está estimado em 29,2 bilhões de litros para safra 2015/16, um incremento de 539,2 milhões de litros, alta de 1,9\% (acessado em julho de 2015 www.conab.gov.br).

O algodão é a principal fonte de fibras naturais para as indústrias têxteis, e, portanto, uma das fontes mais abundantes de biomassa agroindustrial, com uma produção de 24 milhões de toneladas no mundo em 2006-2007 e um aumento anual de 2\% (Shen \& Agblevor, 2008).

A produção global de fibras para a indústria têxtil e outras aplicações tem aumentado constantemente nas últimas décadas. Em 2007, a produção de fibras ultrapassou 68,7 milhões de toneladas, onde o algodão contribui com mais de 27 milhões de toneladas seguido do poliéster com a maior participação no mercado (YNFX, 2008).

As fibras podem ser reutilizadas e acabam em estações de resíduos. Se as fibras estão na forma de, por exemplo, algodão puro ou de poliéster, há diferentes técnicas de reciclagem ou de reutilização em larga escala. No entanto, resíduos têxteis são geralmente misturados às fibras. $\mathrm{O}$ aterro é a principal prática de descarte de resíduos têxteis na maior parte dos países. 
No entanto, a deposição de resíduos orgânicos é proibida na União Europeia e em alguns outros países (Jeihanipour et al., 2010).

A parte celulósica de resíduos têxteis como o algodão ou a viscose que constitui cerca de $40 \%$ dos resíduos totais de tecidos, pode ser utilizada como uma biomassa renovável alternativa para a produção rentável de produtos por meio de processos microbianos. O etanol é um dos produtos que pode ser produzido a partir de resíduos têxteis à base de algodão pela hidrólise enzimática seguida da fermentação (Jeihanipour and Taherzadeh, 2009).

O levantamento de safras realizado pela Conab aponta para uma produção brasileira de algodão em pluma na temporada 2014/15 de 1.505,9 mil toneladas, ocupando uma área de 976,2 mil hectares, 13\% menor que a temporada passada. Essa redução ocorre em função dos baixos preços alcançados pela arroba da pluma. O algodão é uma cultura de custo bastante elevado e os produtores operam de forma estratégica, estimando custos de produção e vendas antecipadas do produto, com o intuito de obter margens de lucro que permita comparar com alternativas, como por exemplo, o cultivo da soja. A redução observada na área plantada foi influenciada pela atual conjuntura adversa, tanto interna quanto externa, onde os estoques elevados promovem a queda nos preços da pluma. A Região Centro-Oeste, principal produtora da fibra, foi a que apresentou a maior redução na área neste exercício - 106,7 mil hectares. Entre os principais estados produtores, Goiás registrou redução de 37\%, seguido de Mato Grosso com 12,5\% e a Bahia com $12 \%$. Atualmente a cultura, tanto da primeira quanto da segunda safra encontra-se nas fases de frutificação e maturação (acessado no site em julho de 2015 - www.conab.org.br)

O alto nível de produção de algodão está diretamente relacionado com a alta produção de resíduos e detritos. Nos EUA, cerca de 2,5 milhões de toneladas de resíduos são produzidos a cada ano (White et al., 1996).

Os resíduos da colheita de algodão são de dois tipos: o lixo algodoeiro (CPT) e o lixo descaroçador de algodão (CGT). O CPT é o resíduo que permanece no campo depois da colheita do algodão, enquanto o CGT é o resíduo que provém do processo de descaroçamento. Desses dois tipos de resíduos, o CGT é muito importante para os pesquisadores e os produtores de algodão, devido à alta produção e as dificuldades de descartá-lo (Plácido et al., 2013).

$\mathrm{Na}$ indústria de fios, o fardo do algodão é limpo e uniformizado, e então ocorre a separação e estiramento das fibras de algodão. Todas as impurezas obtidas na fase de processamento são recolhidas por tubulações e acumuladas em filtros, gerando o resíduo 
conhecido por pó de filtro. Já o piolho de algodão é obtido pela etapa de separação dos fios das fibras de algodão, que não possuíram características físicas boas o suficiente para se tornarem fios (Paganni et al, 2011).

A soja é uma planta oriunda da China, de comportamento primordial rasteiro e descoberta pelo Ocidente na segunda metade do século XX A ampliação de sua importância no mercado internacional deve-se ao fato de seu grão ser a principal fonte de óleo vegetal comestível e o farelo ser amplamente utilizado na formulação de ração. Além disso, a lavoura possui uma alta produção por hectare de proteína, sendo fonte, também para o ser humano, de importantes qualidades nutricionais e funcionais (Embrapa, 2005).

No Brasil, a partir da década de 60, a cultura de soja passou a adquirir importância no País, inicialmente na Região Sul (latitudes 30 a $22^{\circ} \mathrm{S}$ ), onde apresentou melhor adaptação, devido à semelhança com as regiões tradicionais de cultivo no mundo. Com a crescente demanda, por matéria-prima protéica nos países desenvolvidos, foram observados o aumento da produção e a rápida expansão da área de cultivo desta leguminosa da Região Sul rumo ao Cerrado, latitudes 20 a $5^{\circ} \mathrm{S}$ (Urben Filho \& Souza, 1993), levando o Brasil de uma posição inexpressiva no cenário mundial para a de segundo maior produtor de soja no mundo (Priolli et al., 2004).

Com o encerramento da colheita da oleaginosa a Conab registrou no levantamento realizado em junho deste ano, o segundo recorde de produtividade alcançado no país - 3.016 $\mathrm{kg} / \mathrm{ha}$ - somente superado pelo obtido na temporada 2010/11 - 3.115 kg/ha. O décimo levantamento de soja realizado pela Conab aponta para uma produção na temporada 2014/15 de $96.222,1$ mil toneladas, representando um incremento de $11,7 \%$ em relação ao montante produzido no ano passado. (Acessado em julho de 2015 no site www.conab.gov.br).

A casca da soja tem uma rica composição celulósica contendo 40-45\% de celulose e 30-35\% de xilana em base seca (Camassola et al., 2007). A grande produção de soja no mundo torna os resíduos lignocelulósicos dessa cultura um dos mais expressivos em volume e uma alternativa importante para a bioconversão do seu hidrolisado à produtos de grande valor agregado.

\section{3- Deconstrução da biomassa vegetal por fungos filamentosos.}

Os polissacarídeos de plantas apresentam aplicações em diferentes setores industriais, tais como: biocombustível, papel e alimento. Celulose, hemicelulose, lignina e pectina são os 
principais componentes da parede celular da planta, representando cerca de $70 \%$ da biomassa (Jorgensen et al., 2007). A biomassa lignocelulósica é o material mais abundante e barato que contêm açúcares disponíveis para bioconversão de etanol (Figura 3) (Corrêa, 2016).

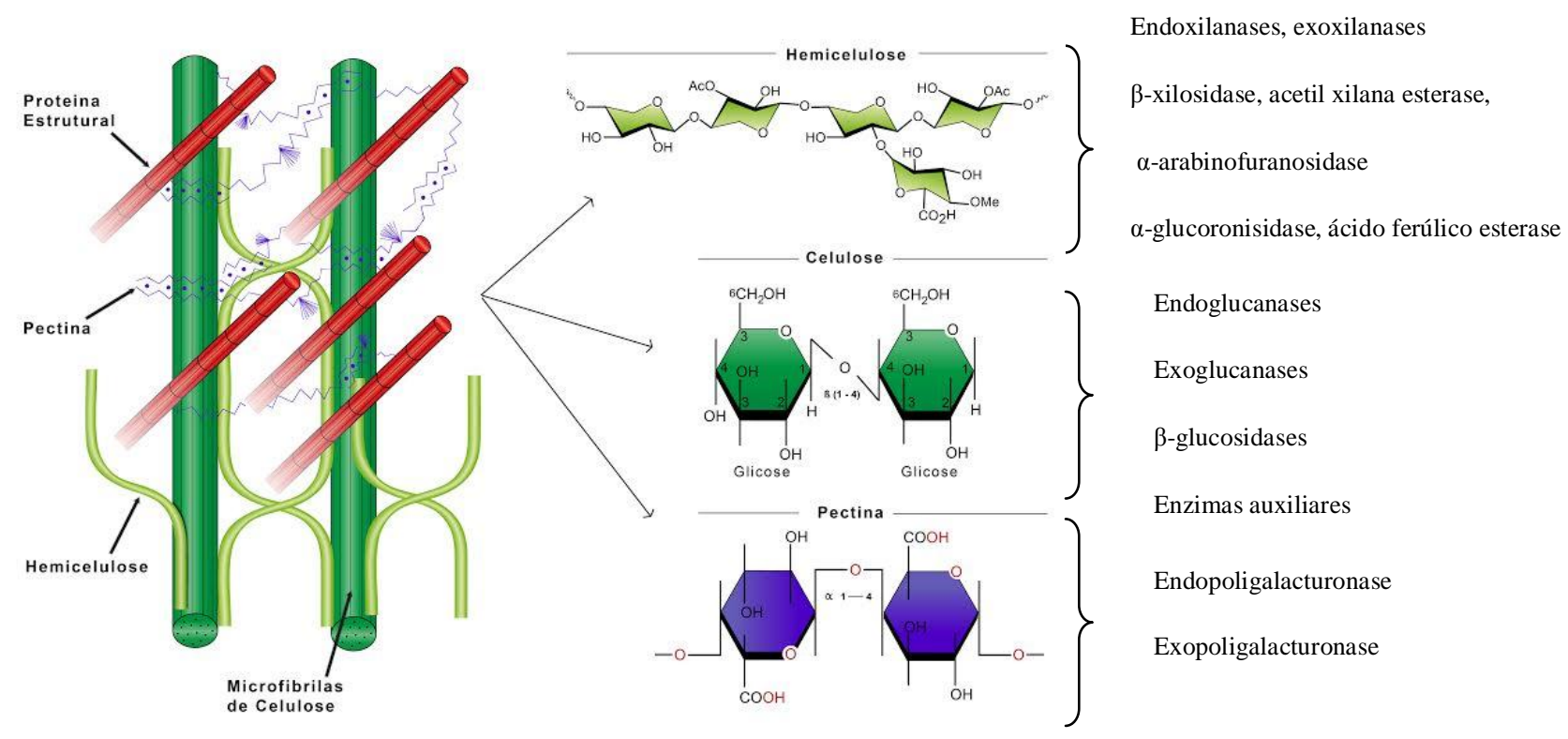

Figura 3: Estrutura da parede celular vegetal, evidenciando celulose, hemicelulose e pectina (Corrêa, 2016)

Celulose (20-50\% em peso seco), hemicelulose (15-35\%), e lignina (10-30\%) são os principais constituintes da parede celular, enquanto que as proteínas (3-10\%), lipídios (1-5\%), açúcares solúveis (1-10\%), e minerais (5-10\%) são os menores componentes. Esta composição química da parede celular difere significativamente entre monocotiledôneas (por exemplo, palha de milho, gramíneas) e dicotiledôneas (por exemplo, Arabidopsis), o que acaba por influenciar sua susceptibilidade à desconstrução (Pauly et al., 2008).

Na parede celular primária, as microfibrilas de celulose são incorporadas numa matriz altamente hidratada. Esta estrutura fornece força e flexibilidade. A matriz é composta por dois grandes grupos de polissacarídeos, geralmente chamado de hemiceluloses e pectinas, além de uma pequena quantidade de proteínas estruturais (Lincoln \& Eduardo, 2002).

A organização das paredes celulares é uma área de intensa pesquisa. Entretanto, a maioria das pesquisas tem sido tradicionalmente centradas nas paredes celulares primária, resultando em muito menos compreensão das paredes celulares secundária, que constituem 
pelo menos $70 \%$ a $80 \%$ da massa do caule dos entrenós. As paredes celulares secundárias são significativamente mais recalcitrantes do que paredes celulares primárias para desconstrução biológica (Himmel et al., 2007).

A celulose é um longo polímero insolúvel em água, constituído por cadeias lineares que contém resíduos D-glicose unidos por ligações $\beta$ - $(1 \rightarrow 4)$. As longas cadeias de glicose são firmemente agrupadas em microfibrilas e são ligadas entre si por hemicelulose (Carpita \& Gibeaut, 1993).

Uma característica importante da matriz cristalina é que as moléculas que compõem as microfibrilas são ligadas suficientemente apertadas para impedir a penetração não só de enzimas, mas também de moléculas pequenas, tais como água (Lynd et al., 2002).

As hemiceluloses são polissacarídeos constituídos por açúcares pentose (xilose e arabinose) e/ou hexoses (glicose, manose e galactose), ácidos urônicos e grupo acetila. A composição exata é fortemente dependente da espécie de planta e do tecido (Sheller \& Ulvskov, 2010).

A pectina é a menos presente na biomassa vegetal em comparação com a celulose e hemicelulose. No entanto, alguns tipos de plantas são abundantes em pectina (exemplo: casca de frutas cítricas). A cadeia principal da pectina consiste principalmente de ligações a 1,4 -Dácido galacturônico que podem ser esterificados ou substituídos por grupo acetila. As pectinas são classificadas em três grandes grupos: homogalacturonanas (polímero linear), xilogalacturonanas (ligação D-xylose do tipo $\beta-1,3$ ) e ramnogalacturonanas (Ridley et al., 2001).

A lignina é um polímero heterogêneo com uma cadeia principal aromática e em geral é formada por três alcoóis: coniferil, cumaril e sinapril (Martinez et al., 2005). A deslignificação do material lignocelulolítico por basidiomicetos é de grande interesse e tem sido investigada para melhorar a digestibilidade da madeira, para alimentação animal e para reduzir custos das indústrias de papel (Vares et al., 1995). A lignina também é conhecida pela resistência à degradação microbiana devido ao seu peso molecular elevado e pela presença de várias ligações biologicamente estáveis. A efetiva conversão da lignina é importante para a utilização de novos materiais e energia (Yang et al., 2011).

Estudos sobre a deconstrução da parede celular vegetal evidenciam o uso de enzimas oxidativas. Sendo assim, o número de oxidases que atuam em hidratos de carbono foi identificado em todos os reinos da vida, embora predominantemente em fungos (Van et al., 2006). Durante o ataque microbiano, essas oxidases promovem a clivagem prolongada de 
componentes da parede celular vegetal. Além disso, evidências recentes destacam o papel crítico de parceiros enzimáticos alternativos envolvidos na oxidação de outros componentes da parede celular. Uma nova classe de enzimas chamada de Atividades Auxiliares (AAs) foi criada no banco de dados do Cazy, sendo esta uma extensa classe de módulos não estritamente restritos a um simples mecanismo catalítico ou específicos substratos, que são caracterizadas e atualizadas no banco de dados pelas suas relevâncias bioquímicas e similaridades com modelos considerados âncoras funcionais. A atual classificação das AAs é dividida em 11 famílias incluindo as subfamílias das famílias AA1, AA3 e AA5 (Tabela 1) (Levasseur et al., 2013). Descritas originalmente como celulases, as enzimas GH61 foram recentemente descobertas por ser monooxigenases de polissacarídeos líticos cobre dependente (LPMO) que melhoram a degradação da celulose em conjunto com celulases clássicas (Bey et al., 2013). As LPMO (GH61) catalisam a clivagem oxidativa de celulose de baixo peso molecular usando agentes redutores, tais como, ascorbato, galato, glutationa reduzida, e lignina (Levasseur et al., 2013). 
Tabela 1. Divisão das subfamílias e atividades da classe AA.

\begin{tabular}{ccc}
\hline (Sub) famílias & Atividade & E.C. \\
\hline AA1 & Multicopper oxidase & \\
\hline AA1_1 & Lacase & 1.10 .3 .2 \\
\hline AA1_2 & Ferroxidase & 1.10 .3 .2 \\
\hline AA1_3 & Lacase-like multicopper oxidase & 1.10 .3 .2 \\
\hline AA2 & Class II peroxidase & \\
\hline & Manganês peroxidase & 1.11 .1 .13 \\
\hline & Lignina peroxidase & 1.11 .1 .14 \\
\hline AA3 & Versatil peroxidase & 1.11 .1 .16 \\
\hline
\end{tabular}

\begin{tabular}{ccc}
\hline AA3_1 & Celobiose desidrogenase & 1.1 .99 .18 \\
\hline AA3_2 & Aril-álcool oxidase/Glicose oxidase & $1.1 .3 .7 / 1.1 .3 .4$ \\
\hline AA3_3 & Álcool oxidase & 1.1 .3 .13 \\
\hline AA3_4 & Piranose oxidase & 1.1 .3 .10 \\
\hline AA4 & Vanilil álcool oxidase & 1.1 .3 .38 \\
\hline AA5 & Radical-copper oxidase & \\
\hline AA5_1 & Glioxal oxidase & $1.1 .3 .-$ \\
\hline AA5_2 & Galactose oxidase & 1.1 .3 .9 \\
\hline AA6 & Glicooligossacarídeo oxidase & 1.6 .5 .6 \\
\hline AA7 & Domínio de ferro redutase & $1.1 .3 .-$ \\
\hline AA8 & Lítica polissacarídeo monooxigenase $(\mathrm{GH} 61)$ & 1. -.-.- $^{-}$ \\
\hline AA9 & Lítica polissacarídeo monooxigenase $(\mathrm{CBM} 33)$ & 1. -.-.- $^{-}$ \\
\hline AA10 & Lítica polissacarídeo monooxigenase & 1. -.-.- $^{\circ}$
\end{tabular}

Fonte: Levasseur, 2013 (atualizado pelo CAZy). Expansion of the enzymatic repertoire of the CAZy database to integrate auxiliary redox enzymes.

Uma grande variedade de enzimas com especificidades diferentes é necessária para degradar os componentes da lignocelulose. Entretanto, muitas outras proteínas também podem contribuir para a degradação da parede celular vegetal em formas ainda não muito bem compreendidas, tais como a família glicosil hidrolases ( $\mathrm{GH}$ 61), as expansinas e soleninas (Van et AL 2012). 
Na era pós-genômica onde a busca por enzimas eficientes para a deconstrução da parede celular vegetal tornou-se um importante tema de investigação, a simultânea identificação de CAZmes e enzimas que degradam a lignina é necessária para descrever o conjunto completo de enzimas que participam da deconstrução da parede celular (Levasseur et al., 2013).

A utilização de celulases requer uma etapa de pré-tratamento para perturbar os materiais de lignina e de cera que protegem a celulose dentro da estrutura de lignocelulose. Este processo de pré-tratamento torna a celulose mais acessível para que as enzimas concluam o processo de hidrólise da lignocelulose. Assim, a eficiência da hidrólise enzimática total é afetada pelo tipo de meio e pelas condições empregadas durante o pré-tratamento. Em outras palavras, a conversão eficaz de lignoceluloses em açúcar simples requer enzimas que são compatíveis com a etapa de pré-tratamento (de Diego et al., 2014).

Algumas pesquisas têm evidenciado que os fungos que degradam a parede celular de espécies como a cana de açúcar de forma natural pode produzir enzimas com a diversidade e atividade adequada para a bioconversão dessas plantas. Estudos anteriores de prospecção biológica em fungos mesófilos descobriram cinco isolados de fungos de bagaço de cana-deaçúcar e madeira com atividades de endoglucanases comparadas favoravelmente com enzimas de Thrichoderma reesei (Basso et al., 2010). Fungos fitopatogênicos também estão sendo estudados e essas pesquisas têm revelado que muitos desses fungos são tão bem ou até melhores na bioconversão do que T. reesei (por exemplo, em xilanas, espécies de Mucor, Rhizoctonia, e Cylindrocarpon foram superiores a T. reesei) (King et al., 2011). Já em fungos termófilos e termotolerantes, 27 cepas isoladas do bagaço de cana-de-açúcar forneceram xilanases e endoglucanases termostáveis (Moretti et al., 2012).

Sendo assim, é comum pesquisas para investigar linhagens de outras espécies fúngicas. Quando o secretoma de Fusarium verticillioides cultivado em palha de trigo foi adicionado as preparações de enzimas comerciais de $T$. reesei, açúcares adicionais foram liberados a partir da celulose (glicose) e hemiceluloses (xilose, arabinose) (Ravalason et al., 2012). Outros pesquisadores investigaram fungos termofílicos, como por exemplo, Thermoascus auraticus cultivado em gramínea (Panicum virgatum L) ou Aspergillus terreus cultivado em palha de milho, encontrando estirpes não melhoradas destes fungos produzindo enzimas que funcionam bem como preparações comerciais atuais e que permanecem ativas a temperaturas elevadas $\left(70^{\circ} \mathrm{C}\right)$ (Shrestha et al., 2015). 


\section{4- A produção de enzimas microbianas.}

Enzimas microbianas têm sido amplamente aplicadas em grande escala, na fabricação bioindustrial de produtos alimentares e farmacêuticos, devido à sua alta especificidade de substrato e estereoseletividade, e sua eficácia em condições brandas com baixo impacto ambiental. Ao mesmo tempo, as técnicas de bioremediação utilizando enzimas microbianas foram desenvolvidas para resolver o problema dos resíduos industriais, nomeadamente no que diz respeito aos produtos químicos persistentes e substâncias tóxicas. E, finalmente, os estudos estruturais destas enzimas têm revelado a base mecanística de reacções enzimáticas, incluindo a estereoseletividade e especificidade de substratos e cofactores de ligação (Tanokura et al., 2015).

$\mathrm{Na}$ natureza, os fungos desempenham um papel fundamental na degradação da biomassa de plantas e apresentam enzimas específicas para esta degradação. No entanto, o conjunto de enzimas difere entre as espécies fúngicas. Por exemplo, Trichoderma reesei tem um conjunto de enzimas altamente eficiente na degradação da celulose (Martinez et al., 2008) enquanto as espécies de Aspergillus são bons produtores de enzimas que degradam a pectina (Martens-Uzunova \& Schaap, 2009).

Embora a hidrólise de polissacarídeos da parede celular de plantas tenha sido objeto de estudo há décadas, a hidrólise enzimática eficiente para a conversão de lignocelulose ainda é uma questão de investigação intensiva (Maijala et al., 2012). Estudos de dados genômicos e proteômicos de fungos indicaram que estes organismos apresentam uma fonte extremamente grande de enzimas hidrolíticas para degradação de polissacarídeos (www.cazy.org). A produção de muitas destas enzimas está sujeita a indução e repressão com base na fonte de carbono presente no meio (Cantarel et al, 2011).

A montagem e degradação de polímeros de carboidratos e glicoconjugados são realizados por um painel diverso de enzimas denominadas Carboidratos-ativos, ou " CAZymes”. O sistema de classificação CAZymes, com base na similaridade de aminoácidos, estrutura de proteínas e mecanismos enzimáticos, foi integrado e atualizado na base de dados cazy (www.cazy.org) desde 1998. O cazy incorpora mais de 300 famílias subdivididas nas seguintes classes: glicosil hidrolases $(\mathrm{GH})$, glicosil transferases $(\mathrm{GT})$, polissacarídeos liases (PL), carboidratos esterases (CE), e módulos de ligação a carboidratos (CBM) (Levasseur et al., 2013). 
Apesar das enzimas dentro da mesma família compartilharem sequências similares, algumas famílias apresentam múltiplas atividades, como por exemplo, a família GH5 que apresenta atividade exoglucanase, endoglucanase e endomanase (Coutinho et al., 2009).

Cepas fúngicas que produzem celulases são compostas principalmente pelos gêneros: Trichoderma, Aspergillus, Penicillium e Fusarium. Cepas de Trichoderma podem acumular altas atividades de endo e exoglucanases, mas são pobres em $\beta$-glucosidases, ao passo que as cepas de Aspergillus apresentam alta atividade de $\beta$-glucosidases (Stockton et al., 1991).

Os fungos filamentosos dos gêneros Trichoderma, Aspergillus e Penicillium, entre outros, têm sido cultivados para a produção de enzimas da família GH. Foi relatado que a expressão de GH em fungos filamentosos geralmente exige indução. Materiais lignocelulósicos podem ser utilizados como fonte de carbono do meio de cultura tanto para o crescimento quanto para indução de complexos de enzimas celulases e hemicelulases em fungos filamentosos. Esta é uma estratégia potencial para a produção de enzimas (Sorensen et al., 2011).

Estudos também têm sugerido que a utilização das enzimas secretadas por fungos filamentosos, crescidos em resíduos lignocelulósicos, pode ser um possível meio de modulação do complexo enzimático produzido (Delabona et al., 2013). No entanto, devido à regulação complexa do sistema de enzimas celulolíticas de fungos, e a natureza complexa dos materiais lignocelulósicos, as respostas fisiológicas dos fungos, em termos de tipo de enzima secretada, a taxa de biossíntese, entre outros, é bastante variável (Rispoli \& Shah, 2007).

Fungos filamentosos, tais como, Aspergillus niger e Trichoderma reesei mostraram produzir uma ampla variedade de enzimas hidrolíticas de polissacarídeos. Recentemente, o genoma de A. niger e T. reesei tornou-se disponíveis (De Souza et al., 2011). Os genomas de A. niger e T. reesei contêm 14.600 e 9.129 genes entre os quais cerca de 200 e 170, respectivamente, estão envolvidos na degradação de polissacarídeos (Martinez et al., 2008).

Em A. niger, a expressão das principais celulases e hemicelulases é coregulada pela mesma molécula indutora (D-xilose), mas os mecanismos de indução de $T$. reesei são mais diversificados. Pelo menos quatro moléculas indutoras diferentes foram descritas, mas nenhuma delas tem o potencial de provocar a expressão de todas as principais celulases e hemicelulases (Stricker et al., 2006).

As celulases, produzidas por uma variedade de bactérias e fungos, provocam a hidrólise da celulose por ação sinérgica dos constituintes enzimáticos compreendendo (a) $\beta$ 1,4-endoglucanase, (b) celobiohidrolase e (c) $\beta$-glucosidase (Doi \& Tamaru, 2001). Como um 
modelo aceito, a indução de celulases é mediada por oligossacarídeos solúveis de baixo peso molecular que são liberados a partir de substratos complexos como resultado da hidrólise por enzimas constitutivas ou pelos produtos (isômeros) de reações de transglicosilação mediada por constituintes $\beta$-glucosidases, xilanases, etc (Badhan et al., 2007).

Estes metabólitos entram na célula e sinalizam a presença de substratos extracelulares fornecendo o estímulo para a síntese acelerada de enzimas constituintes do complexo de celulases. No entanto, este processo é complexo, visto o fato de que muitos fungos e bactérias são conhecidos por expressar funcionalmente múltiplas celulases/ hemicelulases na presença de diferentes fontes de carbono (Nazir et al., 2010). Esta multiplicidade pode ser resultado de: redundância genética, processamento diferencial do mRNA ou modificações pós-traducionais, tais como, glicosilação e digestão proteolítica (Collins et al., 2005).

O grande gargalo da aplicação abrangente de celulases na indústria é o elevado custo da produção da enzima. Redução de custos substancial poderá ser possível explorando formas de conversão da celulose utilizando microorganismos que produzem enzimas celulolíticas. E, por conseguinte, é importante olhar para os microrganismos que têm uma elevada taxa de produção de celulase (Kotchoni and Shonukan, 2002). Embora muitos microorganismos crescam em celulose ou produzem enzinas que degradam a celulose, poucos produzem o conjunto inteiro de celulases extracelulares capazes de degradar a celulose cristalina in vitro. Nos últimos anos o interesse de sistemas em fermentação com cultura mista tem sido revitalizado, e está claro que a construção deliberada e a criação de comunidades microbianas estáveis são uma alternativa viável para muitos problemas biotecnológicos (García- Kirchner, 1983).

O uso de estirpes microbianas que produzem enzimas com novas propriedades é um aspecto urgente desta pesquisa. Todas as enzimas celulolíticas estudadas até agora são caracterizados por uma multiplicidade de componentes da enzima cujo número exato varia de um organismo para outro. Por exemplo, cada componente do sistema de celulase em Trichoderma reesei foi evidenciado por estar presente em uma multiplicidade de formas, com duplicação aparente de função. A natureza e a origem dessas formas isoenzimáticas continuam a ser objeto de muita especulação (Kirchner et al., 2002).

As celulases comerciais são principalmente enzimas extracelulares produzidas por fungos mesófilos ou termófilos. Uma vez que a utilização da celulose ocorre por degradação de enzimas e está relacionada ao processamento industrial e operacional, a aplicação de 
enzimas termoestáveis produzidas por fungos mesófilos ou termófilos parece ser vantajosa (Kim et al., 2005).

A importância de xilanases microbianas tem aumentado no cenário atual, devido as suas imensas aplicações biotecnológicas, principalmente na indústria de alimentos, ração animal, indústrias de papel e celulose, bem como para bioconversão de resíduos lignocelulósicos em produtos químicos de valor agregado. A xilana é o principal constituinte da hemicelulose, que é o segundo recurso renovável mais abundante da Terra. Xilanases microbianas (EC 3.2.1.8) são os catalizadores preferidos para a hidrólise da xilana devido à sua elevada especificidade, condições de reações suaves e formação de produtos secundários. O custo da enzima é um dos principais fatores que determina a economia de todo o processo (Beg et al., 2001).

\section{5- A importância do estudo do transcritoma em fungos filamentosos.}

A genômica funcional ou transcritômica aplicada ao estudo de fungos filamentosos consiste no sequenciamento da porção transcrita do genoma, podendo ter aplicação para a identificação de genes eestudos de expressão gênica diferencial. A análise comparativa em larga escala de genes diferencialmente expressos possibilita isolar genes que conferem ou regulam características essenciais para o desenvolvimento e adaptação às condições ambientais dos microorganismos (Ward et al., 2006).

A área de desenvolvimento de tecnologia de sequenciamento de DNA tem uma rica e diversa história. No entanto, a grande maioria da produção de sequências de DNA até a data tem contado com alguma versão bioquímica do sequenciamento Sanger. Nos últimos dez anos, o incentivo para o desenvolvimento inteiramente de novas estratégias de sequenciamento de DNA surgiu em pelo menos quatro níveis, inegavelmente revigorantes neste campo (Shendure et al., 2004). O surgimento da tecnologia de sequenciamento de última geração (NGS) tem proporcionado uma rápida e eficaz abordagem para a geração de dados do transcritoma de organismos não modelos que não apresentam sequência completa do genoma (Lin et al., 2011).

Os NGS fazem referência a várias implementações de sequenciamento que foram recentemente realizados em um produto comercial, por exemplo, sequenciamento 454 (utilizado nos sequenciadores Genoma 454, Roche Applied), tecnologia Solexa (usado no 
Ilumina, San Diego, Genome Analyzer), a plataforma SOLiD (Applied Biosystems, Foster City, CA, EUA), a Polonator (Dover / Harvard) (Bentley, 2006).

Em comparação com o sequenciamento completo do genoma, o sequenciamento do RNA (RNA-seq), é de baixo custo e elevado rendimento, tornando uma parte importante na pesquisa do genoma funcional. Este sequenciamento fornece uma forma eficiente de identificar o nível de expressão e novos membros de genes (Lin et al., 2011). O RNAseq (sequenciamento de uma amostra de RNA em estado estacionário), é livre de muitas limitações das tecnologias anteriores, tais como a dependência do conhecimento prévio do organismo, tal como exigido por microarrays e PCR. Além disso, o RNA-seq promete desvendar complexidades anteriormente inacessíveis no transcritoma, tal como, a expressão específica de um alelo, novos promotores e isoformas. No entanto, o conjunto de dados produzidos são grandes e complexos e a interpretação não é simples (Wang et al., 2008).

A análise do transcritoma é um método de fenotipagem geral. Utilizando esta técnica, um grande número de genes funcionais pode ser identificado, e os genes diferencialmente expressos entre amostras da mesma espécie podem ser descobertos. A análise do transcritoma é particularmente útil para revelar as relações entre genes, expressão e fenótipos (Lin et al., 2011).

Nos últimos anos ocorreu uma aceleração de publicações em que o sequenciamento de última geração é aplicado para uma variedade de objetivos. Aplicações importantes incluem: (i) resequenciamento do genoma total ou descoberta de mutações ou polimorfismos mais direcionados; (ii) mapeamento de rearranjos estruturais, que podem incluir variação do número de cópias, translocação cromossômica e inversões; (iii) "RNA-Seq", análoga à sequência expressa (EST) ou análise serial da expressão gênica (SAGE), onde bibliotecas derivadas a partir do mRNA ou de pequenos RNAs em grande profundidade sequenciadas (Shendure et al., 2005).

Em comparação com o tamanho do genoma de outros eucariontes tais como animais e plantas, o tamanho do genoma de fungos é pequeno. S. cerevisiae e $S$. pombe têm tamanhos de genoma de 13,7 MB e 13,8 MB, respectivamente. Exceto para o ascomiceto Ashbya gossypii, que tem um tamanho de genoma de $8.9 \mathrm{MB}$, outros ascomicetos filamentosos e basidiomicetos têm tamanhos de genoma entre 13-42 MB (Wood et al., 2002). Além disso, genomas fúngicos têm uma densidade de gene alta, e uma baixa proporção de sequências repetitivas. Por exemplo, S. cerevisiae contem um gene aproximadamente a cada $2 \mathrm{~KB}$, enquanto que o genoma de $N$. crassa contém um gene a cada 4 KB (Le et al., 2002). 
Entre as aplicações da análise do genoma funcional de Trichoderma e Aspergillus, está a compreensão dos mecanismos presentes na dinâmica de genes envolvidos na síntese de enzimas de valor industrial. A partir das primeiras análises de ESTs, o perfil transcricional de fungos potencialmente lignocelulolíticos, mediante à meios de cultura específicos têm sido realizado e contribuído para a identificação de novos ESTs e genes diferencialmente expressos. T. reesei tem sido o foco de extensivos estudos transcricionais mediante as diferentes condições de cultivo, tais como indutores: celulose, soforose e lactose (Foreman et al., 2003).

Visto que os fungos potencialmente lignocelulolíticos produzem enzimas hidrolíticas de acordo com a fonte de carbono utilizada, estudos têm focado na compreensão da dinâmica transcricional desses fungos voltada para a hidrólise da parede celular de resíduos agroindustriais. Um exemplo disso, é o estudo que visa o entendimento de como os genes que codificam enzimas hidrolíticas de A. niger são influenciados pelo bagaço da cana-de-açúcar, baseado em análise de microarranjo de 3.700 genes de A. niger, 18 genes que codificam celulases tiveram aumento de expressão em resposta ao bagaço da cana em comparação com a frutose. Resposta semelhante ocorreu com 21 genes que codificam hemicelulases (De Souza et al., 2011).

Genes requeridos para o crescimento e atividade enzimática sobre polímeros como celulose foram analisados por NGS no organismo modelo Neurospora crassa, com os fatores crll e crl2 identificados como responsáveis na indução dos genes das principais celulases e hemicelulases neste fungo (Coradetti et al., 2012). Delmas et al. (2012) relatou a aplicação de RNA-Seq SoLID para analisar o transcritoma em A. niger. O estudo revelou que aproximadamente $19 \%$ do total de mRNA está envolvido na expressão de genes relacionado a enzimas que degradam a parede celular da planta após 24 horas de exposição a palha de trigo. Esta é uma forte representação de grupos de genes CAZy, uma vez que representam apenas 2,5\% do genoma codificante. As diversas categorias de genes CAZy expressos durante a exposição a palha de trigo reflete a complexidade dos carboidratos presentes no substrato.

Os estudos visando à tecnologia NGS são importantes para a compreensão dos mecanismos genéticos em fungos lignocelulolíticos para explorar o potencial biotecnológico de cada organismo estudado. Horta et al. (2014) analisaram o transcritoma do fungo $T$. harzianum cultivado em bagaço da cana com o uso da tecnologia RNA-seq visando conhecer genes envolvidos na degradação da celulose e hemicelulose e genes acessórios envolvidos na despolimerização da biomassa. Foram identificados 487 CAZymes previstos no transcritoma. 
Aproximadamente 164 contigs foram classificados como sendo potencialmente relacionados com a degradação da biomassa e também foi observado um sinergismo sistemático entre as diferentes classes de enzimas para vias metabólicas específicas em T. harzianum. Estas vias incluindo o metabolismo de diversos açúcares, os quais estão associados com a despolimerização da biomassa.

O estudo do transcritoma é uma ferramenta importante para identificar novos genes, envolvidos na regulação e expressão de enzimas essenciais para a despolimerização da biomassa vegetal, tendo como objetivo final a melhoria dos bioprocessos. Desta forma, sendo aplicado para a produção de diferentes co-produtos de interesse industrial. O conhecimento funcional de genes e vias regulatórias em fungos filamentosos, envolvidos na degradação de resíduos agroindustriais como o bagaço da cana-de-açúcar, poderá contribuir para o avanço industrial por meio de novas linhagens de micro-organismos capazes de catalisar a hidrólise da parede celular vegetal e fermentar o açúcar liberado.

\section{6- O fungo Aspergillus terreus.}

O fungo Aspergillus terreus é um fungo filamentoso saprófita da família Aspergillaceae que foi isolado de amostras a partir do solo do deserto, pastagens, bem como de contaminantes de milho, cevada e amendoim (Varga et al., 2005). A. terreus pertence ao gênero Aspergillus, sub-gênero Nidulantes e pode ser identificado em laboratório por meio de métodos morfológicos. Membros desta espécie são diversos em sua morfologia colonial, e pode crescer como colônias laranja brilhante a colônias que parecem com vários tons canela de acordo com a figura 4 (Balajee, 2009). O genoma do A. terreus foi sequenciado pelo Broad Fungal Genome Initiative (estirpe NIH 2624), com tamanho estimado em $29.33 \mathrm{Mb}$, sendo codificado 10.406 genes, com 3414 GO termos anotados. O genoma haplóide dessa estirpe contém um total de 12.834 EST e está organizado em 8 cromossomos de acordo com o banco de dados NCBI (National Center for Biotechnology Information). 


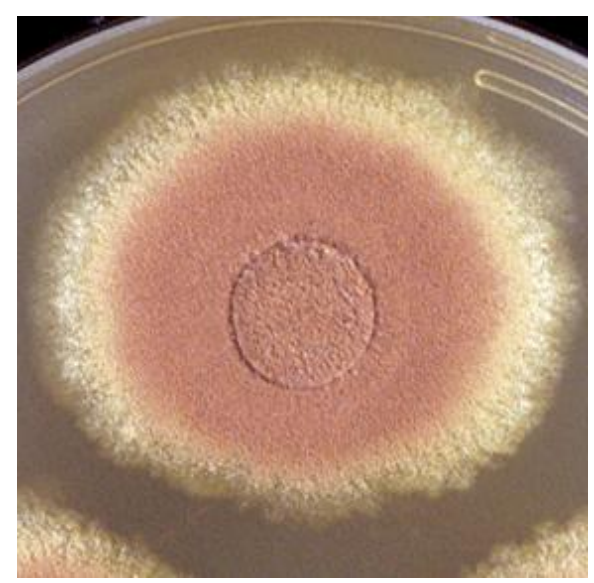

Figura 4: Foto do fungo Aspergillus terreus cultivado em meio de cultura sólido.

(http://www.mycology.adelaide.edu.au/

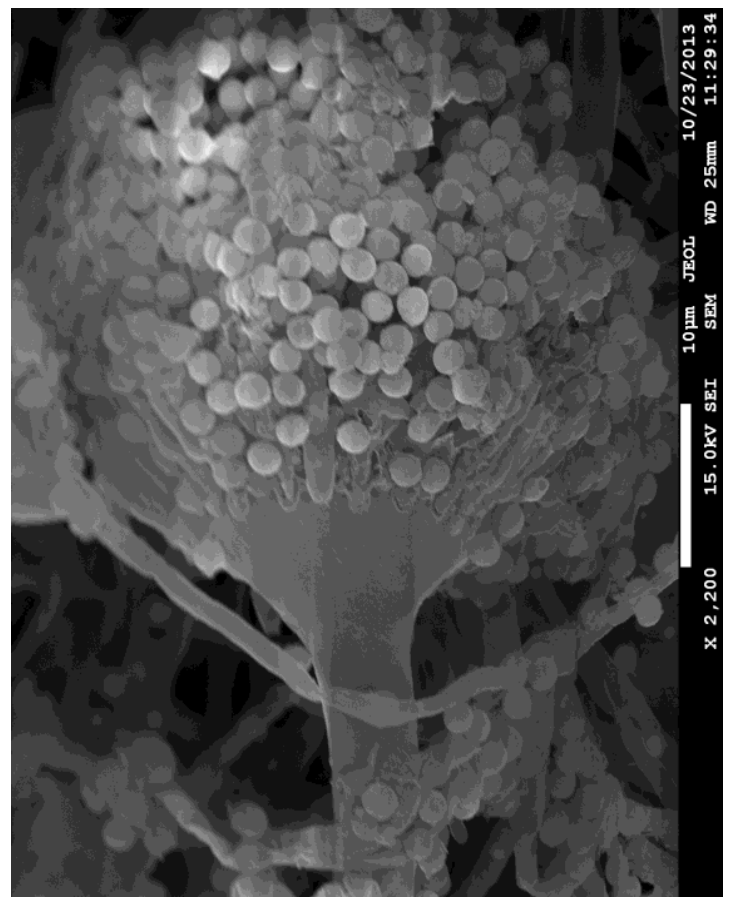

Figura 5: Microscopia eletrônica de varredura do A. terreus (Corrêa, 2013)

O gênero Aspergillus é dividido em sete subgêneros, que por sua vez se subdividem em várias seções, cada seção composta por várias espécies estreitamente relacionadas. Usando métodos morfológicos como delineadores, pesquisadores reconheceram A. terreus como única espécie conhecida dentro da seção terrei. O fungo A. terreus pertence ao grupo de fungos filamentosos que produzem dois tipos de conídios assexual: 1) conídios produzidos principalmente na ponta dos conidióforos e 2) conídios acessórios que emergem lateralmente a partir das hifas (Figura 5) (De Lucca, 2007). 
Esta espécie também é clinicamente importante, pois pode causar infecções que variam desde infecções superficiais, tais como onicomicose, até infecções invasivas como aspergilose em pacientes imunocomprometidos. A. terreus, surgiu como uma causa significativa de aspergilose, e esta infecção transporta uma taxa de mortalidade muito maior do que qualquer uma das mais de 20 espécies de Aspergillus patogênicos, com a mortalidade atingindo $100 \%$ em muitos casos. Importante, A. terreus é completamente resistente à anfotericina B, um tratamento importante para infecções fúngicas. Aspergillus terreus é também a principal fonte de lovastatina, o primeiro medicamento do grupo Estatina, classe aprovada pela FDA (Food and Drug Administration) para o tratamento de hipercolesterolêmica em humanos.

(http://www.broad.mit.edu/annotation/genome/aspergillusterreus/GenomeStats.html).

Este fungo também é utilizado na indústria para a produção de importantes ácidos orgânicos, tais como o ácido itacônico (Symoens et al., 2000). O ácido itacônico desempenha um papel crucial como um monômero ou um aditivo em muitas aplicações industriais, incluindo resinas sintéticas, fibras sintéticas, de vidro artificial, detergentes, tintas (Kuens et al., 2012). Uma informação importante do Departamento de Energia (DOE) dos EUA relatou que o ácido itacônico foi classificado como um dos doze blocos topo de construção de químicos e derivados da biomassa que podem ser usados como um precursor, para a produção de vários produtos químicos ou materiais de origem natural de elevado valor econômico (US., 2004). Até a data, o ácido itacônico é produzido comercialmente por meio da fermentação de Aspergillus terreus, que ocorre no sentido da via glicolítica e a etapa inicial da via oxidativa no ciclo do ácido tricarboxílico (TCA) (Bonnarme et al., 1995).

A. terreus é utilizado para produção de enzimas celulolíticas. A biodegradação de resíduos de lignocelulose por A. terreus foi também estudado por Emtiazi e colaboradores. Gao e colaboradores (2008) em seu estudo de Produção e caracterização de enzimas celulolíticas de Aspergillus terreus (M11) sob cultivo em estado sólido de palha de milho obtiveram resultados que sugerem o uso potencial do isolado M11 de A. terreus para a produção de celulases em um período mais curto e um meio barato. As atividades de endoglucanase, FPase e $\beta$-glucosidase foram 581, 243 e 128U, respectivamente, por grama da fonte de carbono, após 96 horas de incubação, à $45^{\circ} \mathrm{C}$ e ph 3 .

Espécies de Aspergillus são agentes importantes de decomposição e, portanto, apresentam capacidade para produzir uma variedade de enzimas. O gênero é conhecido por ser um bom produtor de celulases. A produção de celulase tem sido descrita para muitas 
espécies de Aspergillus (Wang et al., 2006) mas, há poucos relatos disponíveis sobre a produção de celulase a partir de A. terreus (Emtiazi et al., 2001).

A. terreus por ser um fungo termofílico vem sendo cada vez mais estudado para a produção de enzimas lignocelulósicas sendo eficaz para o uso bilógico. Estudos evidenciam o seu potencial para a produção de celulases e também que a atividade de celulases de algumas estirpes é consideravelmente mais elevada quando comparadas com outras (Gao et al., 2008). Devido ao maior nível de atividade de celulase termoestável ácido ativo, este fungo é visto também como uma importante fonte de enzimas para bioconversão de materiais celulósicos em etanol. A atividade enzimática por meio de gel (PAGE) mostrou a presença de múltiplas endoglucanases e $\beta$-glucosidase em culturas de A. terreus (Soni et al., 2008). 


\section{JUSTIFICATIVA}

No cenário global, a deterioração do meio ambiente tem aumentado por causa do uso de produtos químicos em diversas áreas industriais. Por isso, tem-se investido em pesquisas que possam melhorar o ambiente e promover tecnologia de baixo custo.

O aproveitamento de resíduos, especialmente os agroindustriais tais como, polpa e folhas de café, resíduos de frutas, bagaço de mandioca, farelo de soja, bagaço de cana de açúcar, polpa de beterraba, etc têm se intensificado nos últimos anos. Vários processos biotecnológicos foram desenvolvidos para utilizar esses materiais na produção de álcool, enzimas, ácidos orgânicos, aminoácidos, gerando produtos de grande valor econômico.

O estudo de enzimas é relevante devido a sua alta especificidade e eficiência no processo de catálise, visto que a catálise biológica leva à transformação de reagentes comparativamente não tóxicos em produtos relativamente puros sob condições amenas, tendo como consequência uma redução nos custos do processo. A utilização bem sucedida de enzimas como biocatalisadores industriais requerem a disponibilidade de enzimas com alta atividade específica e termoestabilidade.

A crescente utilização de enzimas na indústria é dependente de uma constante inovação que visa um melhor desempenho e redução de custo. Muitas vezes as atividades celulolíticas e hemicelulolíticas requeridas pelo processo industrial dependem do somatório de diferentes enzimas que trabalham em sinergismo. $O$ conhecimento dos genes que codificam as enzimas lignocelulolíticas, além dos seus mecanismos de regulação, é de interesse para a produção comercial destas enzimas. Atualmente, a regulação da expressão de enzimas lignocelulolíticas é apenas parcialmente entendida em fungos filamentosos. $\mathrm{O}$ principal impedimento tecnológico para a utilização mais generalizada da lignocelulose para produção de combustíveis e produtos químicos é a falta de tecnologias de baixo custo que superem a recalcitrância da estrutura da biomassa vegetal.

As limitações na produção de diferentes produtos da indústria deram origem a um significativo interesse em desenvolver novos organismos capazes de explorar de forma eficiente os produtos da biomassa lignocelulósica. Com isso o estudo do transcritoma de fungos é importante para o desenvolvimento desses novos organismos.

O fungo Aspergillus terreus é produtor de enzimas com um amplo espectro de aplicações tecnológicas nas indústrias têxteis, alimentícia, biocombustível e papel, dentre 
outras. Os resultados obtidos anteriormente no Laboratório de Enzimologia, UnB, demonstraram que a espécie de fungo em questão produz alta atividade específica de celulase e hemicelulase quando crescido em substratos lignocelulósicos, possuindo, portanto, grande potencial de aplicação biotecnológica. Essas enzimas serão de grande utilidade em processos, tais como, a obtenção de etanol a partir de resíduos agroindustriais, mais especificamente o bagaço da cana de açúcar, casca do grão da soja, piolho de algodão, entre outros. O estudo do transcritoma do A. terreus possibilitará a compreensão da biologia do fungo e o conhecimento de enzimas importantes na degradação da biomassa vegetal como a integração dos processos.

A análise do transcritoma do A. terreus tem um alto potencial para associar o perfil da expressão de genes envolvidos com caracteres de interesse econômico, como por exemplo, crescimento rápido, produção de xilanases e celulases, produção de metabólitos secundários, etc. A associação do perfil de expressão gênica é um forte indicativo de sua função e do seu potencial para o melhoramento genético. 


\section{OBJETIVOS}

\subsection{Objetivo Geral}

Analisar os genes diferencialmente expressos do A. terreus BLU24 quando cultivado em resíduos agro-industriais, incluindo bagaço de cana de açúcar e casca do grão da soja como fonte de carbono comparado ao cultivo com glicose.

\subsection{Objetivos Específicos}

- Avaliar a atividade enzimática de holocelulases do isolado A. terreus BLU24 quando cultivado em diferentes fontes de carbono oriundas de resíduos agroindustriais;

- Mapear as sequências gênicas diferencialmente expressas e envolvidas na regulação e expressão de enzimas, fatores de transcrição em cada um dos sistemas por meio de análise bioinformática in silico; 


\section{HIPÓTESE}

Quando cultivado em bagaço de cana de açúcar e casca do grão da soja o fungo $A$. terreus apresenta uma expressão diferencial de genes relacionados a degradação da parede celular vegetal e genes que fazem o controle da expressão gênica. 


\section{MATERIAL E MÉTODOS}

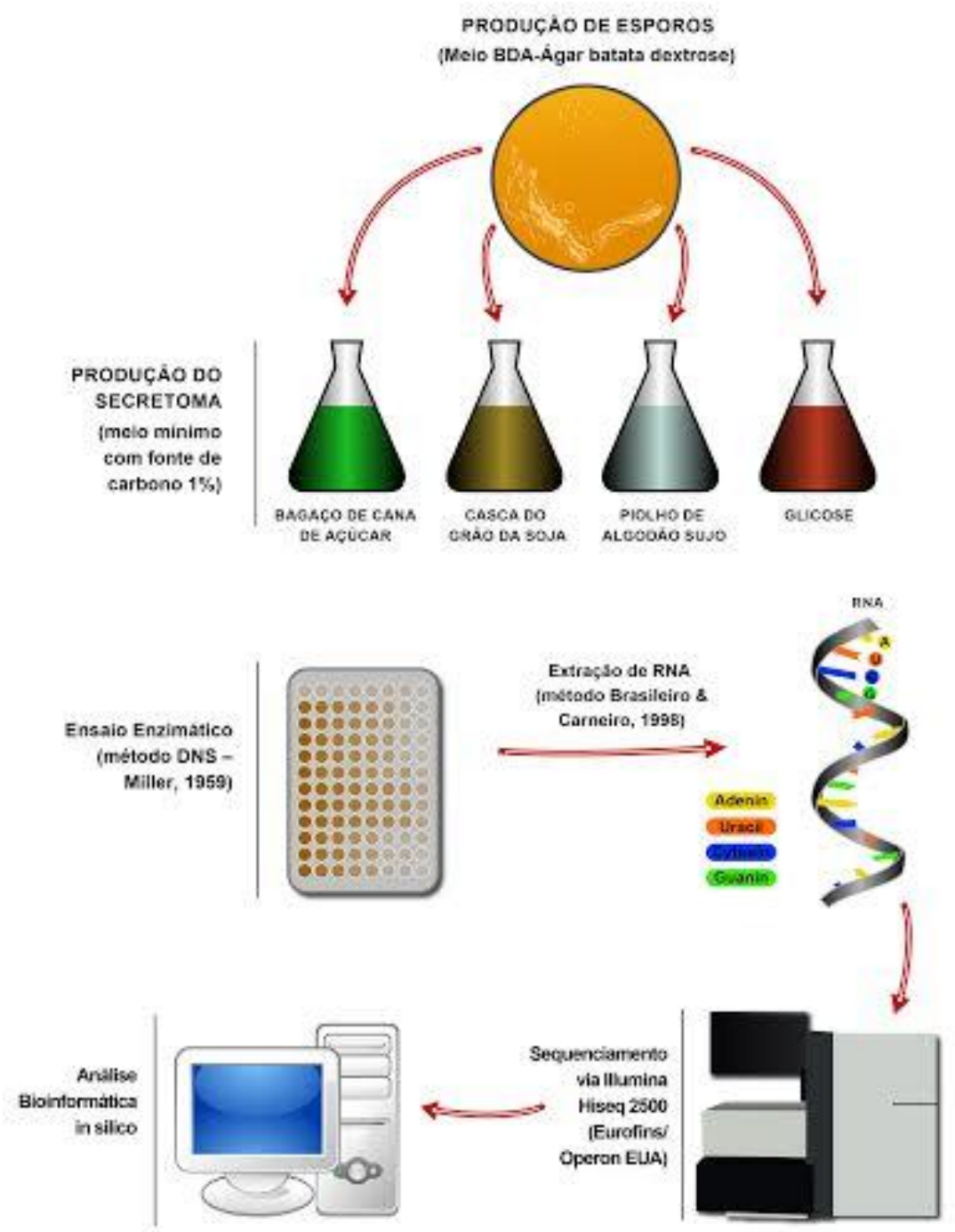

Figura 6: Delineamento experimental (Corrêa, 2016) 

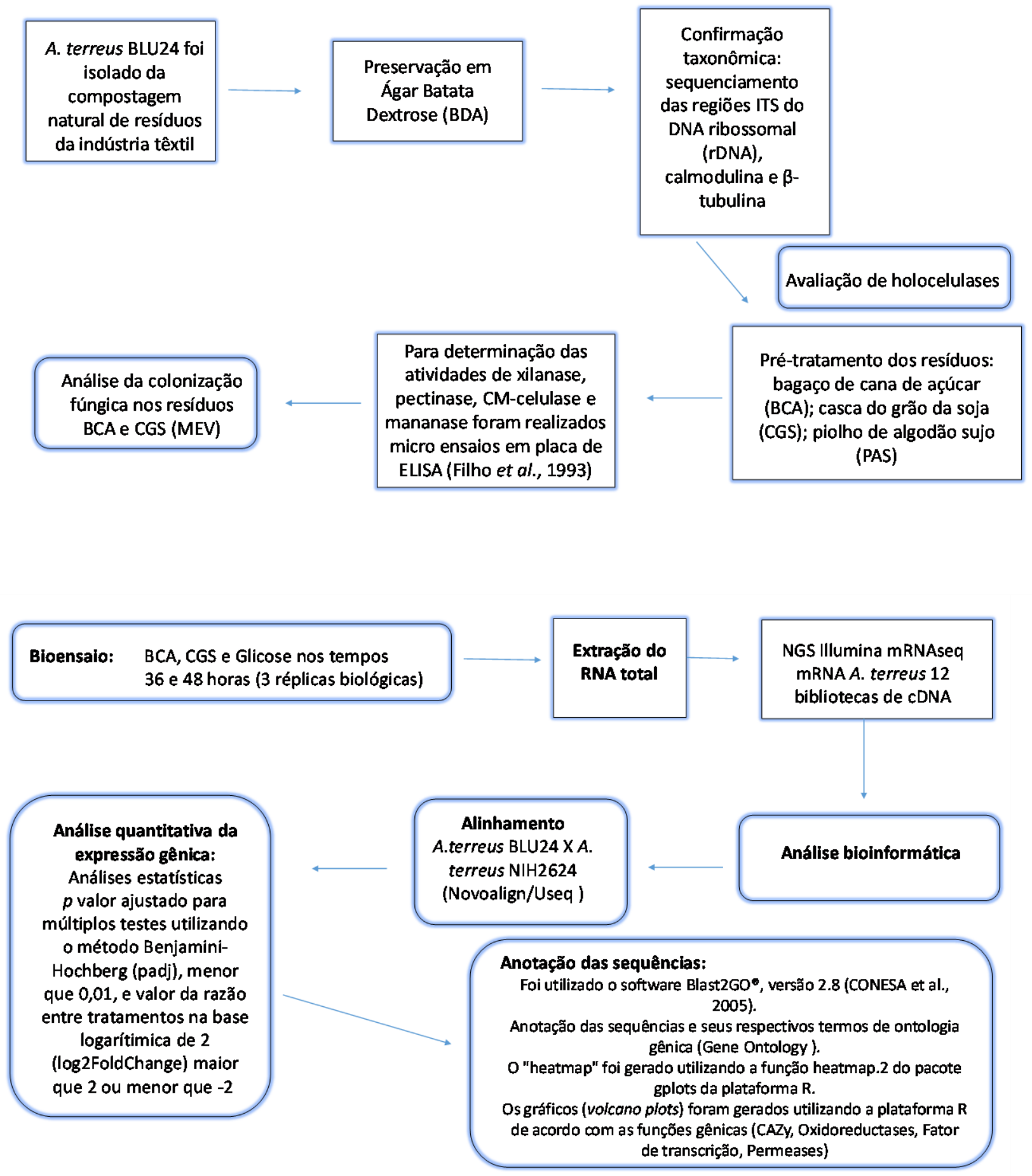

Figura 7: Diagrama mostrando o delineamento experimental (Corrêa, 2016).

\subsection{Origem e Manutenção do Fungo Aspergillus terreus.}

O estirpe A. terreus BLU24 foi isolado da compostagem natural de resíduos da indústria têxtil e, posteriormente, identificado morfologicamente pelo Prof. Dr. Luís Roberto Batista do Laboratório de Microbiologia Agrícola da Universidade Federal de Lavras, Lavras 
- MG, (Siqueira et al., 2010b). A preservação do isolado foi realizada apos cultivo em Ágar Batata Dextrose (BDA- em 1L, caldo de 200g da batata cozida, $2 \%$ de Ágar, 1,5\% de dextrose), com discos de micelio mergulhados em glicerol $50 \%(\mathrm{w} / \mathrm{v})$ à $-80^{\circ} \mathrm{C}$. Para o cultivo da cepa nos experimentos, um disco foi transferido para uma placa de Ágar Aveia (30g de aveia, $13 \mathrm{~g}$ de ágar para $1 \mathrm{~L}$ de água destilada) e após a esporulação foi mantida a temperatura ambiente por um período de 15 dias.

Em seguida, foi feito um pré-inóculo com a ressuspensão dos esporos em solução salina $0,9 \%$ + Tween $801 \%$. A contagem dos esporos para o inóculo foi feita da seguinte forma: em um Becker $(50 \mathrm{~mL})$ foi adicionado a solução de inóculo (solução salina 0,9\% + Tween - 50mL), os esporos crescidos foram raspados com o auxílio de uma lâmina e adicionados na solução e após realizado a contagem em câmara de Neubauer.

\subsection{Identificação molecular}

A confirmação taxonômica do fungo foi feita por análise molecular por meio do sequenciamento das regiões espaçadoras ITS do DNA ribossomal (rDNA), calmodulina e $\beta$ tubulina. Um inóculo do fungo foi adicionado a um fransco erlenmeyer de $250 \mathrm{ml}$ contendo o meio de cultura liquido Czapek com extrato de levedura (CYA) (Pitt \& Hocking, 1985). Apos o cultivo durante três dias a $28^{\circ} \mathrm{C}$, com agitação a $120 \mathrm{rpm}$, foi realizada uma lavagem com água destilada e esterilizada, e filtragem com o auxílio de uma bomba de vácuo para recuperação do micélio. O material foi liofilizado durante 15 horas e a extração de DNA realizada pelo método fenol-clorofórmio (Raeder \& Broda, 1985).

O micélio foi macerado com auxilio de nitrogenio liquido e homogeneizado com 500 $\mu 1$ de tampão de extração ( $\mathrm{NaCl}$ 250mM, Tris $\mathrm{HCl}$ 200mM, EDTA 25mM e SDS 0,5\%). Após foi adicionado $350 \mu \mathrm{L}$ de fenol e $150 \mu \mathrm{L}$ de clorofórmio e as amostras foram homogeneizadas. Em seguida foi realizado uma centrifugação por 30 minutos a 11,8 rpm e a fase aquosa superior foi transferida para um novo tubo. Foi acrescentado 10 unidades de RNAse e a amostra incubada a $37^{\circ} \mathrm{C}$ por 15 minutos. Após foi adicionado igual volume de clorofórmio e uma nova centrifugação a 11,8 rpm por 10 minutos. A fase aquosa superior foi transferida para um novo tubo e o DNA foi precipitado com 54\% de isopropanol gelado. Após, uma centrifugação por 1 minuto a 11,8 rpm e o líquido foi descartado e adicionado 200 $\mu \mathrm{L}$ de etanol $70 \%$ gelado. Uma nova centrifugação por 1 minuto a 11,8 rpm foi feita para lavar o DNA e esse passo foi repetido mais uma vez. Por último o DNA foi seco a 
temperatura ambiente e ressuspendido em $50 \mu \mathrm{L}$ de TE. A quantificação do DNA total foi realizada por comparação visual com o marcador padrão Low DNA Mass Ladder (Invitrogen) por meio de eletroforese em gel de agarose $1 \%$ corado com $1,0 \mu \mathrm{g} / \mathrm{mL}$ de brometo de etídio.

A amplificação das regiões espaçadoras intergênicas do DNA ribossomal nuclear (rDNA ITS 1 e 2) (Figura 8) foi feita utilizando os iniciadores universais ITS5 (forward) e ITS4 (reverse).

(a)

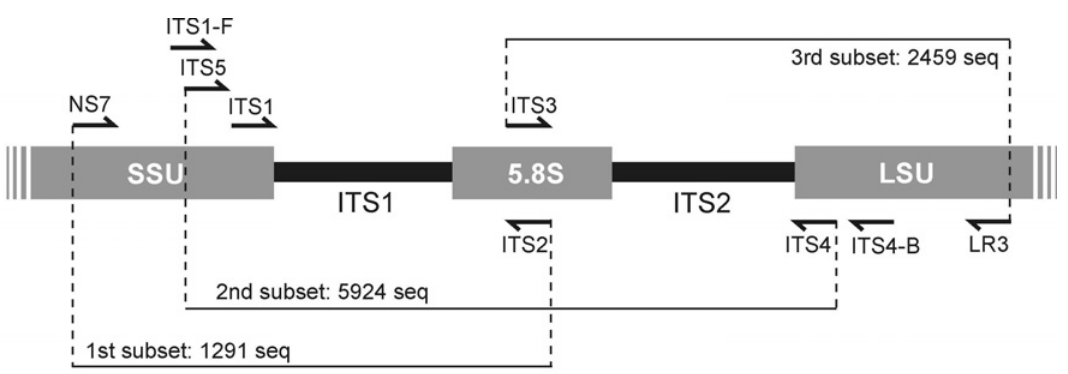

(b)

\begin{tabular}{|c|c|c|c|}
\hline Primer & Author & Primer sequence & Position \\
\hline \multicolumn{4}{|c|}{ Forward primers } \\
\hline NS7 & [19] & GAGGCAATAACAGGTCTGTGATGC & $1403-1426$ \\
\hline ITS1-F & [18] & СПTGTCATTTAGAGGAAGTAA & 1723-1744 \\
\hline ITS5 & [19] & GGAAGTAAAAGTCGTAACAAGG & $1737-1758$ \\
\hline ITS1 & [19] & TCCGTAGGTGAACCTGCGG & 1761-1779 \\
\hline ITS3 & [19] & GCATCGATGAAGAACGCAGC & $2024-2045$ \\
\hline \multicolumn{4}{|c|}{ Reverse primers } \\
\hline ITS2 & [19] & GCTGCGTTCTTCATCGATGC & 20242043 \\
\hline ITS4 & [19] & TCCTCCGCTTATTGATATGC & $2390-2409$ \\
\hline ITS4-B & [18] & CAGGAGACTTGTACACGGTCCAG & $2526-2548$ \\
\hline LR3 & [13] & CCGTGTTTCAAGACGGG & 3029-3045 \\
\hline
\end{tabular}

Figura 8: Iniciadores utilizados para amplificar partes ou a totalidade da região ITS (Bellemain, et al., 2010).

A reação de PCR foi realizada utilizando-se o termociclador ESCO Swift MaxPro com volume final de $20 \mu \mathrm{L}$ contendo: $2 \mu \mathrm{L}$ de tampão da Taq platinum ${ }^{\circledR}$ (Invitrogen) 1X; 0,8 $\mu \mathrm{L}$ de dNTPs $1 \mathrm{mmol}^{-1} ; 0,5 \mu \mathrm{L}$ de cada iniciador a 2,5 $\mathrm{mmol}^{-1}$; 1 U de Taq platinum ${ }^{\circledR}$ (Invitrogen); 0,8 $\mu \mathrm{L}$ de $\mathrm{MgCl}_{2} 2 \mathrm{mM} ; 5 \mu \mathrm{L}$ de DNA (20ng/ $\left.\mu \mathrm{l}\right)$ e 10,2 $\mu \mathrm{L}$ de água Mili-Q.

$\mathrm{O}$ programa de termociclagem utilizado foi de desnaturação inicial à $95^{\circ} \mathrm{C}$ por 2 minutos, desnaturação do DNA à $95^{\circ} \mathrm{C}$ por 1 minuto, anelamento dos iniciadores à $60^{\circ} \mathrm{C}$ por 1 minuto, extensão de $72^{\circ} \mathrm{C}$ por 30 segundos, e extensão final à $72^{\circ} \mathrm{C}$ por 5 minutos, com 30 ciclos de repetição.

O sequenciamento da região rDNA ITS, calmodulina e $\beta$-tubulina foi realizado em sequenciador ABI 3130xl da Applied Biosystems nos sentidos forward e reverse. A reação de 
sequenciamento foi feita com $15 \mathrm{ng}$ do produto da PCR, 3,2 pmol do iniciador ITS5 e 3,2 pmol do iniciador ITS4 e $3 \mu 1$ do kit BigDye V3.1 da Applied Biosystems.

A análise bioinformática das sequências foi realizada com o programa Sequencher v4.8 (Genes Codes Corporation) para o alinhamento, edição e formação de contigs. Por último foi feita a análise BLASTn das sequências contra o banco de dados GenBank no NCBI.

\subsection{Avaliação da produção de holocelulases em A. terreus BLU24}

O fungo A. terreus foi cultivado em quatro fontes de carbono (bagaço de cana de açúcar (BCA), casca do grão de soja (CGS), piolho de algodão sujo (PAS) e glicose $1 \%$ em triplicata.

O bagaço de cana de açúcar foi coletado na Fazenda Brejo, em Formosa, GO. O piolho de algodão sujo foi gentilmente cedido pela Hantex - Resíduos Têxteis Ltda., Gaspar, SC. A casca do grão de soja é proveniente da Fazenda Tropical, em Cabeceiras, GO. O prétratamento dos resíduos foi realizado pela adição de $1 / 2$ do volume de água a cada substrato e autoclavagem a $121^{\circ} \mathrm{C}$ por 2 horas, com posterior lavagem em água destilada. Após a lavagem, este material foi seco a $65^{\circ} \mathrm{C}$ por 48 horas em estufa, sendo então triturado em moinho de bancada para obtenção de pequenas partículas homogêneas.

O cultivo de A. terreus BLU24 em meio líquido foi realizado em frascos do tipo Erlenmeyer de $500 \mathrm{~mL}$, contendo $250 \mathrm{~mL}$ de meio líquido suplementado (m/v) (MS) $\left(\mathrm{KH}_{2} \mathrm{PO}_{4} 0,7 \%, \mathrm{~K}_{2} \mathrm{HPO}_{4} 0,2 \%, \mathrm{MgSO}_{4} .7 \mathrm{H}_{2} \mathrm{O}\right.$ 0,05\%, $\left(\mathrm{NH}_{4}\right)_{2} \mathrm{SO}_{4} 0,1 \%$, extrato de levedura $0,06 \%)$ e meio mínimo (MM) $\left(\mathrm{KH}_{2} \mathrm{PO}_{4} \quad 0,7 \%, \mathrm{~K}_{2} \mathrm{HPO}_{4} \quad 0,2 \%, \mathrm{MgSO}_{4} .7 \mathrm{H}_{2} \mathrm{O} \quad 0,05 \%\right.$, $\left.\left(\mathrm{NH}_{4}\right)_{2} \mathrm{SO}_{4} 0,16 \%\right) \mathrm{pH} 7$, e 1,0\% (m/v) das fontes de carbono: bagaço de cana de açúcar (BCA), piolho de algodão sujo (PAS) ou casca do grão de soja (CGS) (Medeiros, Silva Jr et al., 2007). Todos os meios foram autoclavados a $121^{\circ} \mathrm{C}$ por $30 \mathrm{~min}$. Alíquotas de suspensão de esporos $\left(10^{8}\right.$ esporos $\left./ \mathrm{mL}\right)$ foram inoculadas nos Erlenmeyers, na proporção de $1 \mathrm{~mL}$ de solução de esporos para cada $100 \mathrm{~mL}$ de meio de cultura. O cultivo em cada meio foi realizado por um período de 10 dias a $28^{\circ} \mathrm{C}$, com agitação constante de $120 \mathrm{rpm}$. Os ensaios foram realizados em triplicata.

\subsubsection{Determinação da Atividade Enzimática}


A determinação da atividade enzimática foi avaliada durante 240 horas em intervalos de 24 horas, retirando diariamente alíquotas de $1,0 \mathrm{~mL}$ de substrato de cada frasco Erlenmeyer. As alíquotas foram centrifugadas a $10.500 \mathrm{~g}$ por 1 minuto a $20^{\circ} \mathrm{C}$, e armazenadas a $-20^{\circ} \mathrm{C}$ ate a determinação da atividade enzimática de holocelulases.

Para determinação das atividades de xilanase, pectinase, CM-celulase e mananase foram realizadas micro ensaios, incubando-se $10 \mu \mathrm{L}$ do secretoma e $20 \mu \mathrm{L}$ de solução de cada substrato na concentração de $1 \%$ (xilana, pectina e carboximetil celulose - CMC) ou 0,5\% (manana). Os ensaios enzimaticas foram realizados por $30 \mathrm{~min}$, a $50^{\circ} \mathrm{C}$ (Filho et al., 1993). Após o período de incubação, as reações foram interrompidas pela adição de $60 \mu \mathrm{L}$ de solução do ácido 3,5-dinitro-salicílico (DNS) e novamente incubado a $97^{\circ} \mathrm{C}$ por 10 minutos (Miller, 1959). Após, $45 \mu \mathrm{L}$ de cada reação foram transferidos para uma placa de ELISA e adicionados $155 \mu \mathrm{L}$ de água destilada. A quantificação de celulases totais (FPase) foi realizada adicionando $15 \mu \mathrm{L}$ de cada solução enzimática do secretoma em contato com o papel de filtro Whatman ${ }^{\circledR}$ No.1,0 x 0,6 cm, para posterior incubação por 1 hora a $50^{\circ} \mathrm{C}$. A quantidade de açúcar redutor foi quantificada colorimetricamente pela leitura da absorbância a $540 \mathrm{~nm}$ (SpectraMax M2e, Molecular DevicesCo., EUA). As atividades enzimáticas foram expressas em UI/mL, sendo definida como a quantidade de açúcares redutores liberados na unidade de tempo por mililitro ( $\mu \mathrm{mol}$ de açúcar redutor/min $/ \mathrm{mL}$ ). As curvas padrões foram determinadas com soluções de D-xilose, ácido D-galacturônico, D-glicose e D-manose no intervalo de concentração de $0,2-1,2 \mathrm{mg} / \mathrm{mL}$. Por último foi feito a análise dos resultados por meio de análise gráfica e análise estatística pelo método de Tukey.

\subsection{Análise da colonização fúngica nos resíduos bagaço de cana e casca do grão de soja por meio de microscopia eletrônica de varredura (MEV).}

O fungo A. terreus BLU24 foi cultivado em meio mínimo contendo BCA e CGS 1\% como descrito anteriormente. As amostras de cada substrato pré-tratados colonizadas e não colonizadas por A. terreus BLU24 foram coletadas de acordo com o tempo de cultivo dos ensaios anteriores (36 e 48 horas) de cada fonte de carbono para visualização em MEV. A filtragem das amostras foi realizada com auxílio de bomba de vácuo e em seguida foi adicionado às amostras o tampão Karnovsky (0,05M; pH 7,2) com tempo de incubação de 4 horas. Após as amostras foram lavadas três vezes com o tampão Cacodilato de sódio $\mathrm{CaCo}_{3}$ 
$(0,05 \mathrm{M} ; \mathrm{pH} 7,4)$. Este tampão foi retirado e depois adicionado o tetróxido de ósmio $1 \%$ com incubação de 1 hora no escuro.

Em seguida foi realizado duas lavagens com água destilada e iniciou o processo de desidratação das amostras utilizando acetona em diferentes concentrações (30\%, 50\%, 70\%, $90 \%$ e $100 \%$ ). As amostras foram então lavadas com $\mathrm{CO}_{2}$ liquido à $4^{\circ} \mathrm{C}$ e em seguida foram secas no ponto crítico com $\mathrm{CO}_{2}$ e metalizadas com ouro por dois minutos. Por último as amostras foram visualizadas por meio de microscopia eletrônica de varredura.

\subsection{Análise do transcritoma de A. terreus BLU24}

\subsubsection{Extração de RNA total}

Uma suspensão de esporos de A. terreus BLU24 foi utilizada para o inóculo em meio mínimo contendo as quatro fontes de carbono, como descrito anteriormente, a uma concentração final de $1 \times 10^{8}$ esporos/mL. As culturas foram crescidas em $100 \mathrm{~mL}$ de meio mínimo em frascos de Erlenmeyer de $250 \mathrm{~mL}$ em shaker orbital a $128 \mathrm{rpm}$ e temperatura de $28^{\circ} \mathrm{C}$. Foram realizadas três réplicas biológicas, sendo que para cada réplica biológica foi realizado uma triplicata.

O isolamento do RNA total foi realizado de acordo com o método fenol de Brasileiro \& Carneiro, 1998. As amostras de micélio de A. terreus BLU24 foram coletadas de acordo com o tempo de cultivo (maior produção de enzimas e tempo ideal para a extração de RNA) dos ensaios anteriores (36 e 48 horas), sendo que o meio contendo glicose foi utilizado como controle. As amostras foram maceradas com o auxílio de nitrogênio líquido até obter-se um pó fino e transferido para um tubo de centrífuga de fundo cônico de $50 \mathrm{~mL}$.

Em seguida foram adicionados $6,0 \mathrm{~mL}$ de fenol: clorofórmio: álcool isoamílico (25: 24: 1) e 9,0 mL de tampão de extração NTES (0,1M de $\mathrm{NaCl} ; 10 \mathrm{mM}$ de Tris- $\mathrm{HCl}$ pH 7,5; $1 \mathrm{mM}$ de EDTA; $1 \%$ de SDS). À temperatura ambiente, as amostras foram agitadas vigorosamente por 15 minutos e centrifugadas a $4^{\circ} \mathrm{C}, 10.000 \mathrm{G}$ por 10 minutos. A fase aquosa superior foi coletada e transferida para um novo tubo previamente resfriado. A partir deste passo, as amostras foram mantidas em gelo.

À fase aquosa superior, foi adicionado $1 / 10$ do volume de acetato de sódio $3 \mathrm{M}, \mathrm{pH} 4,5$ e dois volumes de etanol absoluto previamente resfriado e incubado a $-20^{\circ} \mathrm{C}$ por, no mínimo, 
1 hora. Em seguida, centrifugação a $4^{\circ} \mathrm{C}, 10.000 \mathrm{G}$ por 15 minutos e o sobrenadante descartado. O pellet foi dissolvido em $2,5 \mathrm{~mL}$ de água MilliQ autoclavada previamente resfriada e adicionados $2,5 \mathrm{~mL}$ de $\mathrm{LiCl} 4 \mathrm{M}$ e após as amostras são incubadas a $4{ }^{\circ} \mathrm{C}$ por, no mínimo, 3 horas.

As amostras foram centrifugadas a $4^{\circ} \mathrm{C}, 10.000 \mathrm{G}$ por 15 minutos e o sobrenadante descartado. O pellet, translúcido e com aparência gelatinosa foi dissolvido em 1,8 mL de água MilliQ autoclavada previamente resfriada e adicionado $0,2 \mathrm{~mL}$ de acetato de sódio $3 \mathrm{M}, \mathrm{pH}$ 4,5. O RNA total foi então precipitado a $-20^{\circ} \mathrm{C}$ por, no mínimo, 1 hora. As amostras são novamente centrifugadas à $4^{\circ} \mathrm{C}, 10.000 \mathrm{G}$ por 20 minutos e o sobrenadante descartado. Para retirar o excesso de sal foi adicionado $5 \mathrm{~mL}$ de etanol $70 \%$ ao pellet e posterior centrifugação à $4{ }^{\circ} \mathrm{C}, 10.000 \mathrm{G}$ por 3 minutos e o sobrenadante foi descartado cuidadosamente. $\mathrm{O}$ pellet de

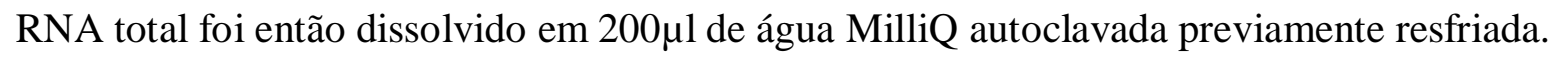

A quantificação do RNA total extraído de A. terreus foi medida através da determinação das absorbâncias (Abs) a 260nm, 280nm e 230nm em espectrofotômetro ND-

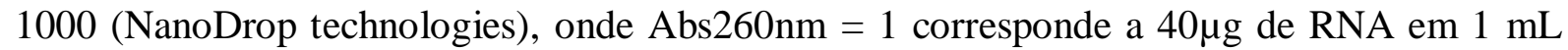
de solução, quando a razão Abs260nm/Abs280nm = 1,9. A razão Abs260nm/Abs230nm é outra medida de pureza, com os valores de um ácido nucléico "puro" em geral na faixa de 1,8 - 2,2. A integridade do RNA total foi avaliada pela intensidade e integridade de bandas de rRNA $28 \mathrm{~S}$ e $18 \mathrm{~S}$, visualizada por meio de eletroforese em gel de agarose $1 \%(14 \mathrm{~V} / \mathrm{cm})$ na presença de brometo de etídio $(1 \mu \mathrm{g} / \mathrm{mL})$ e marcador molecular padrão Low DNA Mass Ladder (Invitrogen). 
Tabela 2: Delineamento experimental dos tratamentos utilizados para a análise do transcritoma do A. terreus. Duas réplicas biológicas foram selecionadas para o seqüenciamento. Cada réplica biológica foi seqüenciada duas vezes (réplica técnica).

\begin{tabular}{|c|c|c|c|}
\hline Fonte de carbono & $\begin{array}{l}\text { Período de Cultivo } \\
\text { (horas) }\end{array}$ & $\begin{array}{l}\text { Réplica } \\
\text { Biológica }\end{array}$ & $\begin{array}{l}\text { Canal do } \\
\text { Illumina } \\
\text { (Flowcell) }\end{array}$ \\
\hline Bagaço de cana-de-açucar & 36 & 1 & 1 \\
\hline Bagaço de cana-de-açucar & 36 & 2 & 1 \\
\hline Bagaço de cana-de-açucar & 48 & 1 & 1 \\
\hline Bagaço de cana-de-açucar & 48 & 2 & 1 \\
\hline Casca de grão de soja & 36 & 1 & 1 \\
\hline Casca de grão de soja & 36 & 2 & 1 \\
\hline Casca de grão de soja & 48 & 1 & 1 \\
\hline Casca de grão de soja & 48 & 2 & 1 \\
\hline Glicose & 36 & 1 & 1 \\
\hline Glicose & 36 & 2 & 1 \\
\hline Glicose & 48 & 1 & 1 \\
\hline Glicose & 48 & 2 & 1 \\
\hline Bagaço de cana-de-açucar & 36 & 1 & 2 \\
\hline Bagaço de cana-de-açucar & 36 & 2 & 2 \\
\hline Bagaço de cana-de-açucar & 48 & 1 & 2 \\
\hline Bagaço de cana-de-açucar & 48 & 2 & 2 \\
\hline Casca de grão de soja & 36 & 1 & 2 \\
\hline Casca de grão de soja & 36 & 2 & 2 \\
\hline Casca de grão de Soja & 48 & 1 & 2 \\
\hline Casca de grão de Soja & 48 & 2 & 2 \\
\hline Glicose & 36 & 1 & 2 \\
\hline Glicose & 36 & 2 & 2 \\
\hline Glicose & 48 & 1 & 2 \\
\hline Glicose & 48 & 2 & 2 \\
\hline
\end{tabular}




\subsubsection{Sequenciamento Illumina HiSeq2500.}

Foram selecionadas duas réplicas biológicas para a análise do transcritoma nos tempos de 36 e 48 horas, sendo que as bibliotecas foram sequenciadas em duplicata (réplica técnica). O cDNA e as bibliotecas foram produzidas a partir do mRNA do fungo A. terreus cultivado sob as três fontes de carbono (glicose, bagaço de cana de açúcar e casca do grão de soja) utilizando-se o kit TruSeq RNA Sample preparation Kit v2 (® Illumina, Inc.) de acordo com instruções do fabricante. As amostras de RNA total foram previamente quantificadas e transportadas em RNAstable (Biomátrica), de acordo com as instruções do fabricante.

As bibliotecas foram submetidas ao sequenciamento massal no Eurofins / Operon, EUA utlizando-se a tecnologia Illumina HiSeq 2500 (HTTP://illumina.ucr.edu/ht). As moléculas de RNA contendo poli-A foram purificadas utilizando Sera-mag Magnetic Oligo(dT) Beads (Illumina) de aproximadamente 10 $\mu$ g para cada amostra de RNA total. O mRNA eluido foi fragmentado por cátions divalentes à temperatura elevada antes da síntese de cDNA.

As duplas fitas de cDNA foram sintetizadas a partir de fragmentos de mRNA por iniciadores aleatórios, utilizando SuperScript II, RNaseH e DNA Pol I. O cDNA foi purificado a partir do kit QIAquick PCR Purification Kit (Quiagen) e as extremidades reparadas e fosforiladas com T4 DNA polymerase, Klenow DNA polymerase e T4 PNK, e purificado mais uma vez. Para permitir a ligação dos adaptadores, uma única cauda de adeninas foi adicionada ao final 3' utilizando Klenow Exo (Illumina).

A ligação dos adaptadores ocorreu de forma que as amostras de cDNA foram agrupadas e sequenciadas em um mesmo canal flowcell de acordo com a fonte de carbono. A seleção por tamanho das amostras $(200 \pm 25 \mathrm{pb})$, enriquecidas por PCR, foi feita por meio de eletroforese e subsequente excisão em gel de agarose TAE $2 \%$.

Os fragmentos foram purificados utilizando o kit QIAquick Gel Extraction (Qiagen). Um total de 15 ciclos de amplificação de PCR foi realizado para enriquecimento das bibliotecas de cDNA com o uso de iniciadores complementares aos adaptadores ligados. Os produtos de PCR foram purificados com o kit QIAquick Gel Extraction (Qiagen), após foram quantificados por meio do Agilent Technologies 2100 Bioanalyzer e por último sequenciados em dois canais flowcel pelo sistema Ilumina Hiseq2500. O sequenciamento Paired-end (2x 100 bases), nos dois sentidos da fita de cDNA foi realizado pelo Truseq RNA Chemistry v3. 


\subsubsection{Mapeamento dos reads e identificação dos transcritos}

As sequências com alta qualidade, previamente selecionadas, foram alinhadas ao genoma de referência de A. terreus NIH2624 v2.3, disponível na plataforma FungiDB (http://fungidb.org/fungidb/app/record/DatasetRecordClasses.DatasetRecordClass?dataset_id =37), para o mapeamento das regiões gênicas. O mapeamento das sequencias de cada biblioteca foi realizado em modo batch utilizando o programa Novoalign/Useq (http://www.novocraft.com/documentation/novoalign-2/novoalign-user-guide/rnaseqanalysis-mrna-and-the-spliceosome/), o que permitiu a análise dos resultados de forma individualizada. Como parâmetros utilizaram-se: (i) penalidade para mismatches: 2; (ii) penalidade para inserção: 3; (iii) custo para deleção: 3; (iv) fração mínima de comprimento: 0,90; (v) fração mínima de similaridade: 0,95; (vi) número máximo de hits por read: 10; e (vii) distância entre paired reads determinada automaticamente.

\subsubsection{Análise quantitativa da expressão gênica}

Após o alinhamento dos reads com o genoma de referência, as sequências mapeadas foram usadas na determinação da expressão gênica diferencial putativa. A contagem do número de reads mapeados por módulos gênicos foram obtidas pelo HTSeq-count (Simonet al., 2014), um software Python aplicado para o processamento de dados a partir de ensaios de sequenciamento de alto rendimento (http://wwwhuber.embl.de/users/anders/HTSeq/doc/counting.html\#counting). Análises estatísticas foram empregadas para identificar genes, unicamente mapeados, com mudanças significativas no número de reads entre os tratamentos experimentais realizados com diferentes fontes de carbono - bagaço de cana-de-açucar (B), casca de grão de soja (S), glicose (G) - após 36 e 48 horas de cultivo. Os cálculos foram realizados com software EdgeR (Robinson et al., 2010) e para cada tratamento foram selecionados genes diferencialmente expressos com significância estatística, $p$ valor ajustado para múltiplos testes utilizando o método Benjamini-Hochberg (padj), menor que 0,01 , e valor da razão entre tratamentos na base logarítimica de 2 (log2FoldChange) maior que 2 ou menor que -2 , ou seja, foram considerados como 
diferencialmente expressos os genes que tiveram variação na expressão igual ou maior que quatro vezes entre os tratamentos avaliados.

\subsubsection{Anotação das sequências}

A anotação das bibliotecas de expressão foi realizada a partir da determinação da função putativa das sequências genômicas contra as quais as bibliotecas foram mapeadas. Para isso, foi utilizado o software Blast2GO®, versão 2.8 (CONESA et al., 2005). As sequências foram comparadas com aqueles presentes no banco de dados proteico não redundante (NR) do NCBI, empregando o algoritmo BLASTx e considerando um número máximo de 3 hits por entrada e o Expect Value mínimo de $10^{-6}\left(\mathrm{E}_{\text {value }} \leq 1.10^{-6}\right)$. Em seguida, realizou-se a anotação das sequências e seus respectivos termos de ontologia gênica (Gene Ontology, THE GENE ONTOLOGY CONSORTIUM, 2000) usando os parâmetros padrões do Blast2GO. As análises de sub-representação e sobre-representação associadas aos genes e produtos de acordo com a categoria de ontologia gênica foram feitas com o teste de Fisher encapsulado no programa Blast2GO, posteriormente, os termos redundantes foram eliminados e as categorias sumarizadas pelo programa REVIGO (http://revigo.irb.hr/).

O gráfico do tipo "heatmap" foi gerado utilizando a função heatmap.2 do pacote gplots da plataforma R. Para tal, uma tabela contendo os valores de $\log 2 \mathrm{FC}$ de 1257 genes diferencialmente expressos em pelo menos uma comparação foi gerada. Os gráficos do tipo vulcão (volcano plots) foram gerados utilizando a plataforma $\mathrm{R}$ através do uso de funções básicas da plataforma. Para tal, tabelas contendo os valores de $\log 2 \mathrm{FC}$ e valor-p ajustado, assim como a classificação gênica de acordo com as funções gênicas (CAZy, Oxidoreductases, Fator de transcrição, Permeases) foram usadas como input. 


\section{RESULTADOS E DISCUSSÃO}

\section{1- Identificação molecular do isolado BLU 24}

Com a extração do DNA do isolado BLU 24 foi possível visualizar a integridade, pureza e intensidade das bandas obtidas por meio de eletroforese em gel de agarose $1 \%$. Todas as amostras de A. terreus foram quantificadas e apresentaram aproximadamente 200 ng/ $\mu \mathrm{L}$ de DNA. As regiões ITS do RNA ribossomal são regiões conservadas do DNA que auxiliam no estabelecimento de relações filogenéticas e distinção de espécies (Chen et al., 2004). Com o resultado da amplificação da região ITS foi obtido um fragmento com tamanho de aproximadamente $610 \mathrm{bp}$ de acordo com o descrito na literatura e a amostra foi sequenciada para a confirmação taxonômica do isolado BLU 24. Foi realizado também o sequenciamento das regiões codificantes para Calmodulina e $\beta$-tubulina para identificação molecular do isolado. Para a identificação do isolado, a sequência nucleotídica encontrada foi comparada com aquelas depositadas no banco de dados NCBI (National Center for Biotechnology Information website), utilizando o programa BLAST para pesquisa das espécies. Com uma homologia de semelhança de 99\% com acessos de Aspergillus terreus disponíveis no GenBank (em anexo) foi possível confirmar a posição taxonômica do isolado BLU 24.

A.terreus pertence ao gênero Aspergillus, subgênero Nidulantes e pode ser identificado por meio de técnicas morfológicas e moleculares. Os membros dessa espécie apresentam uma morfologia colonial diversa e podem crescer como colônias laranja brilhante para colônias que aparecem com vários tons de canela (Balajee 2009). Já a identificação molecular pode ser realizada utilizando diferentes regiões do DNA. As técnicas de diagnóstico molecular conhecidas fundamentam-se na análise direta ou indireta da composição e na sequência dos ácidos nucléicos para identificação e caracterização de organismos (Marques et al., 2002). Aqui a confirmação taxônomica do isolado BLU24 foi realizada por meio de três regiões: ITS, $\beta$-tubulina e Calmodulina e ambas as regiões confirmaram a posição taxonômica do isolado BLU24, sendo para a região ITS com A. terreus (JG6511), Calmodulina A. Terreus (CCF 2911) e $\beta$-tubulina A. Terreus (CCF 2911).

A região ITS está localizada entre os genes 18SrDNA e 28SrDNA e pode ser amplificada por oligonucleotídeos iniciadores específicos (Hillis \& Dixon, 1991). Enquanto 
as regiões dos genes ribossomais são altamente conservadas dentro da espécie, as regiões dos espaçadores ITS, por evoluirem mais rapidamente, podem variar intraespecificamente na sequência de bases e no comprimento, sendo frequentemente usadas para taxonomia de espécies e gêneros (Antoniolli et al., 2000). Recentemente, várias regiões do genoma de fungos têm sido analisadas em conjunto com o ITS, entre as quais a $\beta$-tubulina, Calmodulina, Glutamina sintetase, Actina e Gliceraldeído 3-fosfato desidrogenase.

\section{2- Avaliação da produção de holocelulases pelo fungo $A$. terreus}

De acordo com o teste Tukey $(\mathrm{p}<0,05)$ não houve diferença significativa entre as atividades enzimáticas dos secretoma de A. terreus BLU24 após cultivo nas três fontes de carbono (BCA, CGS e PAS). A atividade de xilanase após cultivo no meio contendo piolho de algodão sujo atingiu um valor máximo de 0,935 UI. $\mathrm{mL}^{-1}$ no sexto dia de cultivo (figura 9C), já no meio com bagaço de cana de açúcar este valor foi de 1,017 UI.mL ${ }^{-1}$ no sétimo dia (figura 9B) e no meio contendo casca do grão da soja a atividade máxima foi também no sétimo dia, atingindo um valor de 1,019 UI.mL ${ }^{-1}$ (figura 9A). O perfil de produção enzimática quando cultivado em meio mínimo (MM) e meio suplementado com extrato de levedura (MS) $1 \%$ atingiu um platô nas primeiras quarenta e oito horas de cultivo.

Comparando os resultados obtidos em meio mínimo e meio suplementado com extrato de levedura só houve diferença significativa $(\mathrm{p}<0,024)$ na atividade de Fpase no meio contendo piolho de algodão sujo. A produção enzimática do isolado BLU24 cultivado em piolho de algodão sujo foi menor quando comparado com cultivo com casca do grão de soja e bagaço de cana de açúcar. Por isso esta fonte de carbono foi excluída da análise do transcritoma do A. terreus. A curva para pectinases atingiu um valor máximo de $0,085 \mathrm{UI} / \mathrm{mL}^{-}$

${ }^{1}$ em piolho de algodão sujo, já para casca do grão de soja o valor máximo foi de 0,494 $\mathrm{UI} / \mathrm{mL}^{-1}$. 

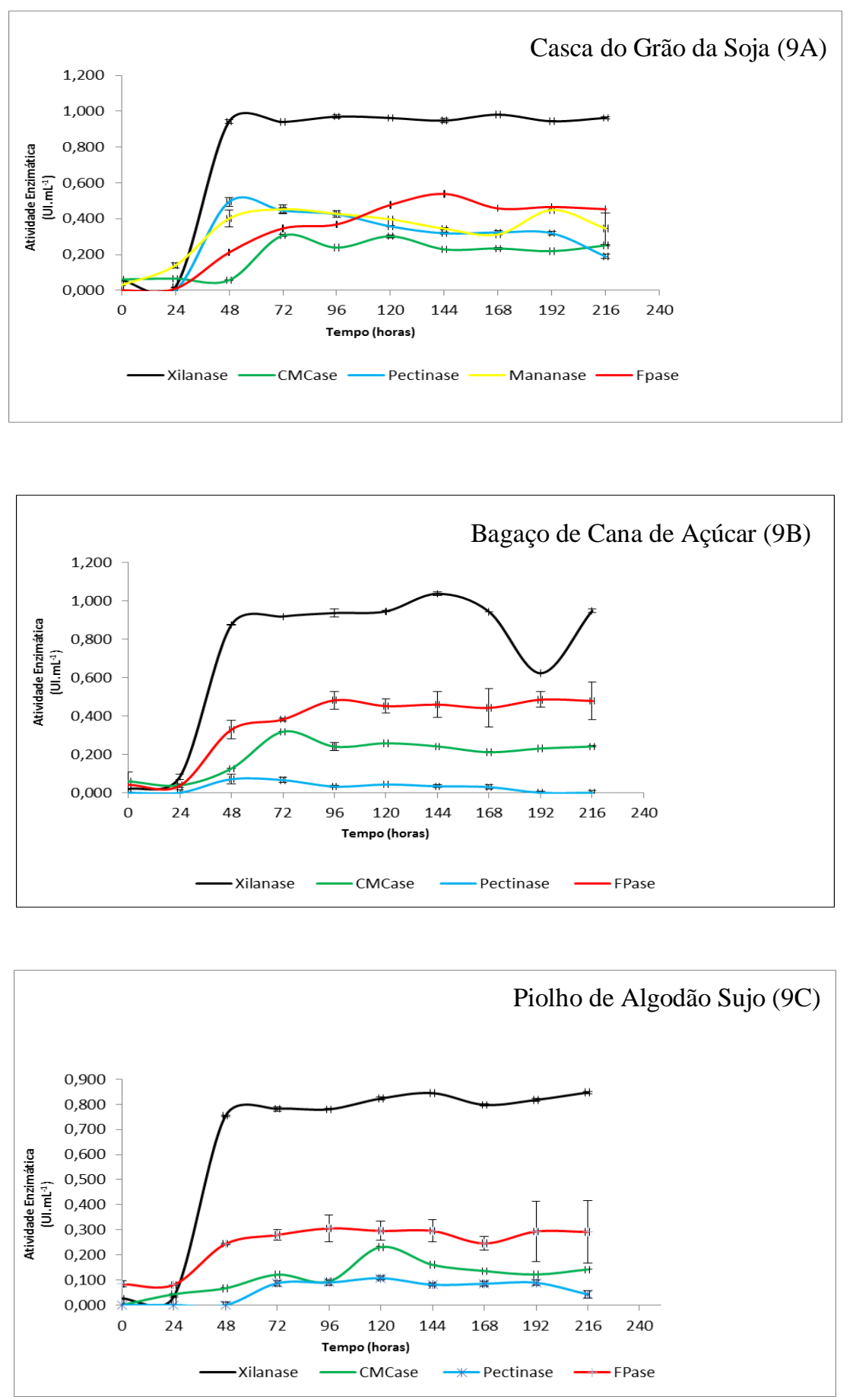

Figura 9: Perfil de produção de holocelulases pelo isolado A. terreus BLU 24 cultivado em meio suplementado com extrato de levedura $1 \%$ - (A) contendo casca do grão da soja pré-tratado como fonte de carbono; (B) contendo bagaço de cana de açúcar e (C) contendo piolho de algodão sujo. Quantificação da atividade xilanase (linha preta), pectinase (linha azul), FPase (linha vermelha), CMCase (linha verde), Mananase (linha amarela). 
A análise da produção de mananases foi realizada apenas após cultivo no meio contendo casca do grão da soja, com a atividade atingindo o seu valor máximo no terceiro dia de cultivo, alcançando 0,453 UI. $\mathrm{mL}^{-1}$. Os dados bromatológicos, resultado do trabalho de Siqueira (2009) (tabela 3) corroboram com o perfil enzimático observado no presente trabalho.

Tabela 3: Dados bromatológicos retirados do trabalho de Siqueira et al (2009), mostrando a porcentagem de celulose, hemicelulose e lignina dos resíduos agroindustriais utilizados no presente trabalho.

\begin{tabular}{cccc}
\hline Resíduos Lignocelulósicos & \% Celulose & \% Hemicelulose & \% Lignina \\
\hline Casca do grão de soja & 16,7 & 44,4 & 5,2 \\
\hline Piolho de algodão sujo & 9,8 & 65,7 & 6,3 \\
\hline Bagaço de cana de açúcar & 16,2 & 34,6 & 5,1 \\
\hline
\end{tabular}

O perfil enzimático do fungo A. terreus BLU24 após cultivo em bagaço de cana de açúcar foi semelhante à casca do grão de soja, com a atividade de xilanase atingindo o seu valor máximo $\left(1,018 \mathrm{UI} / \mathrm{mL}^{-1}\right)$ no sétimo dia. A produção de FPases foi a segunda maior, atingindo $0,455 \mathrm{UI} / \mathrm{mL}^{-1}$ no quinto dia de cultivo.

A conversão microbiana da celulose e hemicelulose é uma importante área da pesquisa biotecnológica. O uso de microrganismos produtores de enzimas com novas propriedades é um aspecto fundamental desta pesquisa. Analisando os resultados obtidos no presente trabalho com os dados da literatura foi possível verificar que o fungo A. terreus é considerado um fungo promissor, devido a sua capacidade em produzir proteínas extracelulares em diferentes condições ambientais e também por ser um fungo termofílico. Para a completa degradação da parede celular vegetal é necessário à ação sinérgica de diferentes enzimas e $A$. terreus demonstrou produzir tanto celulases quanto hemicelulases. Sharma e colaboradores (2014) relataram em seu estudo que uma comparação com a produção de celulases por fungos termófilos em diferentes substratos relatados na literatura, A. terreus RWY teve uma produção de celulases de forma significativa e em um tempo relativamente menor demonstrando assim uma maior produtividade enzimática.

Tanto $\beta$-manosidase quanto $\beta$-glucosidase são necessárias para uma hidrólise completa de pequenos oligômeros que consiste em glucose e manose. Foi observado um nível de atividade de $\beta$-glucosidase relativamente baixo nos filtrados de cultura de organismos testados em diferentes fontes de carbono; apenas A. terreus crescido em goma de feijão e farelo de 
trigo produziu níveis elevados de $\beta$-glucosidase e em contraste, a atividade foi muito menor em meio contendo pectina e flocos de solka (Maijala et al., 2012).

O estudo de uma mistura durante a fermentação com dois fungos filamentosos ( $A$. terreus e Penicillium $s p$ ) para avaliação da produção de celulases e xilanases foi realizado por Kirchner e colaboradores (2002) e os resultados experimentais obtidos demonstraram que a fermentação mista de cultura com Penicillium sp. CH-TE-001 e A. terreus CH-TE-013 produziu filtrados com maior teor de proteína, celulase (principalmente $\beta$-glucosidase), e atividades de xilanase após 2 dias de incubação em comparação com a cultura individual de cada estirpe sob as mesmas condições utilizando uma forma simples de bagaço de cana de açúcar como única fonte de carbono.

Em seu estudo de expressão diferencial de celulases em A. terreus, Nazir e colaboradores (2010) observaram que a regulação de $\beta$-glucosidase apresenta um padrão complexo de repressão e estímulo seletivo na presença de distintos açúcares e álcoois de açúcar. Os resultados do presente estudo indicam que a expressão de múltiplas endoglucanases em A. terreus foi sequencial. A máxima expressão de quatro isoformas de endoglucanases foi observada na presença de palha de arroz (28 U/G DW substrato) e em espigas de milho $(1.147 \mathrm{U} / \mathrm{ml})$ sob substrato sólido e cultura em frasco sob agitação, respectivamente. Além disso, a indução sequencial de isoformas de endoglucanases parece estar associada com a presença de metabólitos distintos (monossacarídeos/oligossacarídeos), como, xilose. A. terreus é um fungo com significativa relevância na indústria biotecnológica. Este fungo é frequentemente isolado de resíduos agrícolas e materiais celulósicos e as suas enzimas têm sido amplamente estudada e utilizada em vários bioprocessos (Han et al., 2010).

A produção de xilanase por $A$. terreus foi anteriormente investigada em diferentes meios de cultura, tais como, aveia e xilana e níveis alto de produção de xilanases foram obtidos assim como no presente estudo (Marques et al., 2003; Hrmová et al., 1989). Aqui a atividade de xilanase nas primeiras 24 horas foi alta nas três fontes de carbono estudada como mostra a figura 8. A. terreus também é conhecido por ser um bom produtor de xilanases. Para a hidrólise completa de xilanas a partir de plantas anuais ou madeira, além de endoxilanases, potencialmente são necessários acetilesterases, $\alpha$-arabinosidases e ácido ferúlico esterases, assim como $\beta$-xilosidases. No trabalho de Maijala e colaboradores, A. terreus cultivado em farelo de trigo produziu a mais elevada atividade de $\alpha$-arabinosidase, seguido por Thermomyces lanuginosus, M. cinnamomea e Myceliophthora fergusii. O padrão geral de atividade mananolítica em $A$. terreus foi interessante visto que produziu quantidades 
significativas de $\beta$-mananase, $\alpha$-galactosidase e $\beta$-glicosidase sobre o meio LBG (galactomanana). (Maijala et al., 2012).

Outro dado relevante do estudo de Maijala e colaboradores (2012) é que várias hidrolases (endoglucanase, xilanase, mananase, $\beta$-glucosidase, $\beta$-Xylosidase e $\alpha$ galactosidase) apresentaram boa estabilidade térmica, não apresentando perda notável de atividade após incubação de uma hora à $65^{\circ} \mathrm{C}$. Isto indica que as espécies estudadas $(A$. terreus, T. lanuginosus, M. cinnamomea e $M$. fergusii) oferecem fontes potenciais para melhor caracterização de hidrolases termoestáveis. Em cada espécie testada, pelo menos uma enzima apresentou estabilidade térmica.

Apesar de existir consórcios enzimáticos, como o Celluclast (Novozymes) do T. reesei, novos estudos visando o uso de preparoções enzimáticas termoestáveis é importante para aumentar o potencial hidrolítico desses consórcios enzimáticos. A. terreus tem demonstrado ser um bom produtor de enzimas necessárias para realizar a hidrólise de celulose e hemicelulose e por ser um fungo termofílico também poderá ser um alvo no futuro para melhorar as preparações enzimáticas existentes e conhecer a sua biologia é fundamental para alcançar esse objetivo.

Gao e colaboradores (2008) demonstraram a influência de várias fontes de carbono na biossíntese de celulases em A. terreus e a palha de milho foi a melhor fonte para a produção de CMCase, FPase e $\beta$-glucosidase entre os materiais lignocelulósicos testados. Os resultados mostraram alto nível de atividade de celulases à $45^{\circ} \mathrm{C}$ em palha de milho com $0,8 \%$ de extrato de levedura como fontes de carbono e nitrogênio. Com as atividades de $581 \mathrm{U}$ para endoglucanase, $243 \mathrm{U}$ de FPase e $128 \mathrm{U}$ de $\beta$-glucosidase por grama de fonte de carbono em SSF por 96 horas, $45^{\circ} \mathrm{C} \mathrm{e} \mathrm{pH} \mathrm{3.} \mathrm{As} \mathrm{celulases} \mathrm{foram} \mathrm{estáveis} \mathrm{em} \mathrm{pH}$ ácido à $70^{\circ} \mathrm{C}$. Essas propriedades sugerem que as celulases podem ser utilizadas como enzimas chave para a produção de bioetanol a partir de celulose. No passo subsequente da hidrólise enzimática, celulases ácidas e tolerantes ao calor poderiam simplificar o processo e reduzir o custo da produção. O trabalho de Gao e colaboradores evidenciou que A. terreus é um fungo potencial para a produção de celulases em um período curto e em meio barato. A produção de CMCase do presente trabalho em bagaço de cana, piolho de algodão sujo e casca do grão da soja não foi muito expressiva, evidenciando que essas fontes de carbono agiram de forma diferente que a palha de milho do trabalho de Gao.

Estudos demonstraram que a eficiência da produção de enzimas também depende da composição química da matéria prima, além da acessibilidade dos vários componentes. Além 
disso, estudos têm evidenciado que a fonte de carbono é essencial para induzir a secreção de diferentes enzimas. Maijala e colaboradores em um estudo com A. terreus demonstraram que a regulação de várias hidrolases (endoglucanase, xilanase, mananase) é dependente da fonte de carbono. Neste estudo a fonte de carbono utilizada foi o farelo de trigo que é uma fonte complexa e atua como potencial indutor para fungos, como A. terreus. O farelo de trigo é um indutor eficaz de hemicelulases, pois, contém uma elevada quantidade de hidratos de carbono solúveis, necessário para iniciar o crescimento e a indução das hemicelulases (Maijala et al., 2012).

Hetero-1,4- $\beta$-D-xilanos e 1,4- $\beta$-D-hetero-mananas são duas estruturas importantes e representativas da hemicelulose, sendo que a xilanas compreendem o maior componente de hemicelulose em madeiras e ervas, enquanto que mananas são mais proeminentes nas hemiceluloses de resinosas e em estruturas especializadas, tais como sementes de plantas e frutas. O presente estudo analisou a atividade de mananase do isolado BLU24 no meio contendo casca do grão da soja e este atingiu o seu valor máximo no terceiro dia alcançando 0,453 UI. $\mathrm{mL}^{-1}$. O consórcio de diferentes enzimas mananolíticas seria benéfico para uma hidrólise completa da glucomanana contida nos diferentes substratos. A ação sinérgica de mananases, juntamente com outras enzimas; tais como, $\alpha$-galactosidase, acetil esterases glucomanana, $\beta$-manosidase e $\beta$-glucosidase, é necessário para a hidrólise completa de galacto (gluco) mananas acetiladas (Dhawan and Kaur, 2007).

Em um estudo com a estirpe de A. terreus foi detectado níveis mais significativos de mananase sob as fontes de carbono: farelo de trigo, goma de alfarroba e pectina. A atividade de mananase foi fortemente induzida por galactomanana (LBG) neste fungo. Da mesma forma, a atividade de mananase em Malbranchea cinnamomea foi induzida por estas fontes de carbono. A. terreus produziu mensuráveis atividades de $\alpha$-galactosidase em todos os meios estudado, mas o nível mais elevado foi no meio LBG. De fato, os níveis de atividade de $\alpha$ galactosidase foram associados com a elevada atividade de mananase (Maijala et al., 2012).

Coradetti e colaboradores (2012) sugeriram que algumas espécies fúngicas desenvolveram mecanismos independentes para a expressão de genes de celulases e hemicelulases em resposta a indutores diferentes a partir da celulose ou da hemicelulose. Celobiose e os produtos de sua transglicosilação têm sido considerados como as moléculas primárias de indução para as celulases fúngicas.

A análise de atividade enzimática nas três fontes de carbono estudada evidenciou que A. tereus BLU24 é um bom produtor de xilanases e celulases e um importante fungo para 
degradar a biomassa vegetal, esses resultados corroboram com estudos citados anteriormente. Também a partir da análise do perfil enzimático foi possível escolher os tempos de 36 e 48 horas para a análise do transcritoma, visto que as curvas de todas as atividades estudadas atingem um platô nas primeiras 48 horas. Isto significa que neste tempo o fungo já está secretando uma variedade de enzimas e moléculas indutoras para iniciar a degradação da biomassa e como o RNA é uma molécula instável e que degrada facilmente esses dois tempos foram escolhidos visando estes dois fatos: produção enzimática e extração de RNA.

\section{3- Análise da colonização do fungo $A$. terreus cultivado nos resíduos: bagaço de cana de açúcar e casca do grão de soja (pré-tratados) por meio de microscopia eletrônica de varredura (MEV).}

A figura 10A mostra à estrutura do substrato bagaço de cana de açúcar pré-tratado e a figura 10B a estrutura do substrato casca do grão de soja pré-tratado, ambos na ausência do fungo A. terreus. Essas figuras mostram pouca estratificação dos substratos pré-tratados. As figuras 10C, D, E, F, G e H mostram a colonização do isolado BLU24 nos substratos bagaço de cana de açúcar e casca do grão da soja, nos tempos de 36 e 48h e em diferentes resoluções (200, 450 e 2000X). As imagens de microscopia evidenciam o desenvolvimento do fungo $A$. terreus sobre estes substratos.

As imagens $\mathrm{G}$ e $\mathrm{H}$, apresentam o fungo em bagaço de cana e casca do grão de soja, respectivamente, ambos no tempo de $48 \mathrm{~h}$ e com resolução 2000X, evidenciam o desenvolvimento fúngico sobre a biomassa. Foi possível visualizar alterações na estrutura da biomassa devido à colonização do fungo sobre a superfície, comparando com as figuras A e B que foram utilizadas como controle (fibras intactas). Na figura $\mathrm{H}$ (casca do grão de soja 48h) fica evidente a penetração do fungo A. terreus na estrutura da fibra. Este resultado mostra que o pré-tratamento a vapor pode ter facilitado a colonização fúngica.

A microscopia eletrônica de varredura permitiu visualizar as fibras dos substratos antes e após a colonização do A. terreus nos dois tempos utilizados em etapas anteriores para extração do RNA. Como ambos os substratos passaram por uma etapa de pré-tratamento, foi possível visualizar e comparar a estrutura das fibras utilizadas no experimento. As imagens de microscopia evidenciam o desenvolvimento fúngico sobre estes substratos. Pode-se sugerir dessa maneira, que o fungo utiliza os compostos presentes nos substratos para seu desenvolvimento. Outra observação das imagens de microscopia é que o fungo apresenta 
crescimento com penetração na estrutura da fibra (figura 10H). Estes resultados mostram que o pré-tratamento além de desestruturar as fibras dos substratos, a torna mais suscetível à colonização fúngica que é um passo crucial na degradação total do bagaço de cana de açúcar e da casca do grão da soja.

O caráter altamente recalcitrante da lignocelulose nativa pode ser sensivelmente atenuado pela explosão a vapor. A modificação estrutural, observada na parede celular vegetal em decorrência do pré-tratamento deixa um resíduo celulósico fibroso do qual a lignina pode ser facilmente extraída com álcali, etanol ou solventes orgânicos (Focher et al., 1988). O efeito da explosão a vapor sobre a organização estrutural da celulose aumenta consideravelmente a sua área superficial e, por conseguinte, a sua suscetibilidade à hidrólise ácida e/ou enzimática (Baudel et al., 2006).

Com as imagens de microscopia eletrônica de varredura foi possível detectar que $A$. terreus BLU24 é capaz de degradar os substratos estudados e a partir dos resultados de atividade enzimática e MEV foi determinado as condições de estudo do transcritoma do $A$. terreus. 


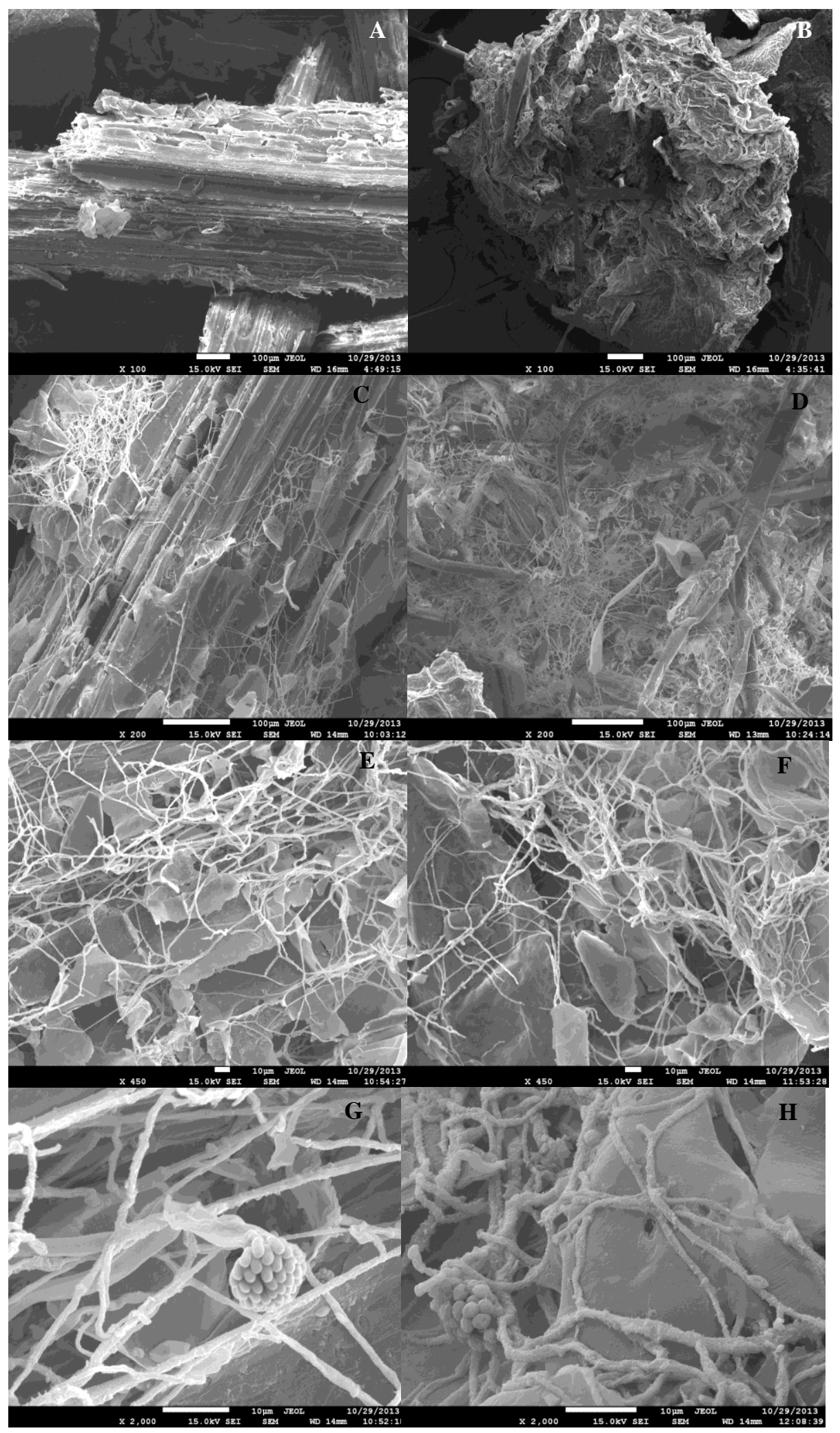

Figura 10: Microscopia eletrônica de varredura da colonização do fungo A. terreus cultivado em resíduos agroindustriais. (A) BCA 100X; (B) CGA 100X; (C) BCA 36 horas 200X; (D) CGS 36 horas 200X; (E) BCA 48 horas 450X; (F) CGS 48 horas 450X; (G) BCA48 horas 2000X; (H) CGS 48 horas 2000X. 


\subsection{Análises dos dados do transcritoma do fungo $A$. terreus cultivado em resíduos agroindustriais.}

\subsection{1- Extração de RNA total}

As amostras de RNA das três réplicas biológicas (Bagaço de cana de açúcar_BCA; Casca do grão da soja_CGS e Glicose) denominadas A, B, C, E, F, G, H, I e J foram extraídas nos tempos de cultivo descrito anteriormente (36 e 48h) utilizando o protocolo de Brasileiro \& Carneiro (1998). A integridade foi examinada por meio de eletroforese em géis de agarose e corado com brometo de etídeo, de acordo com a figura 11.

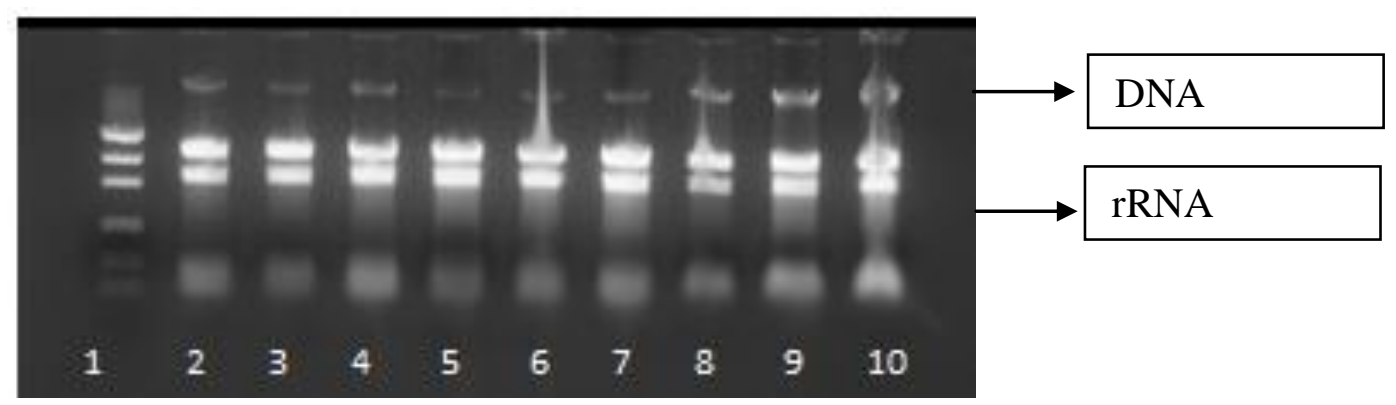

Figura 11: Comparação da integridade das amostras de RNA total do A. terreus BLU24, extraído de acordo com o protocolo de Brasileiro \& Carneiro (1998). Canaleta 1-Low DNA Mass Ladder (Invitrogen); 2- Glicose 36A; 3- Glicose 36B; 4- Glicose 36C; 5- Bagaço 36A; Bagaço 36B; 7Bagaço 36C; 8- Soja 36A; 9- Soja 36B; 10- Soja 36C.

A integridade do RNA total de A. terreus extraído com o protocolo de Brasileiro \& Carneiro foi observado. O RNA total intacto deve mostrar de forma nítida bandas do RNA ribossômico (rRNA) $28 \mathrm{~S}$ e $18 \mathrm{~S}$ em organismos eucarióticos. A intensidade da banda $28 \mathrm{~S}$ deve ser aproximadamente duas vezes da banda 18S, o que é uma indicação da integridade do RNA na proporção de 2:1. O RNA degradado aparece com um rastro e mancha próximo ao final do marcador molecular, com a falta de bandas bem desenhadas. Contaminação com DNA genômico aparece como uma pequena banda de alto peso molecular.

Após a análise da integridade das bandas de RNA foi feito a quantificação das amostras por meio de absorção U.V utilizando espectrofotometria, medida a 260 e $280 \mathrm{~nm}$ pelo NanoDrop. Os resultados da quantificação mostraram uma alta qualidade na integridade e pureza das amostras de RNA total. 
As concentrações finais das amostras de RNA total variaram entre 0,9 a $497 \mu \mathrm{g} / \mu 1$. Duas réplicas biológicas foram selecionadas para a análise do transcritoma do fungo $A$. terreus.

A integridade das amostras de RNA selecionadas para análises por Illumina RNAseq foi verificada por meio do uso do sistema Agilent 2100 Bioanalyzer / RNA LabChip ${ }^{\circledR}$ kits system (Agilent Technologies) (Figura 12). Essa abordagem permite a quantificação das amostras de RNA com precisão, além da avaliação da qualidade e integridade do RNA ribossomal (28S e $18 \mathrm{~S}$ ). O sistema trabalha com no mínimo 10ng de RNA e gera um dado conhecido por RIN (número de integridade do RNA) (Schroeder et al., 2006). O software que gera a escala do algorítimo RIN considera 1 para RNA muito degradado e 10 para RNA intacto. O RIN das amostras variou entre 5.2 e 7.2 como mostra a figura abaixo. 


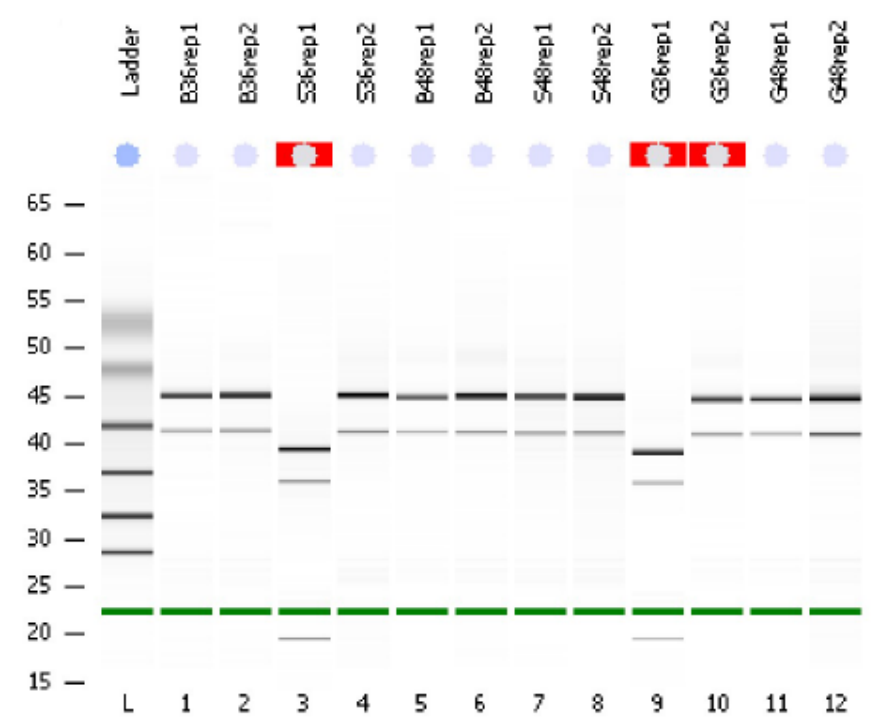

B
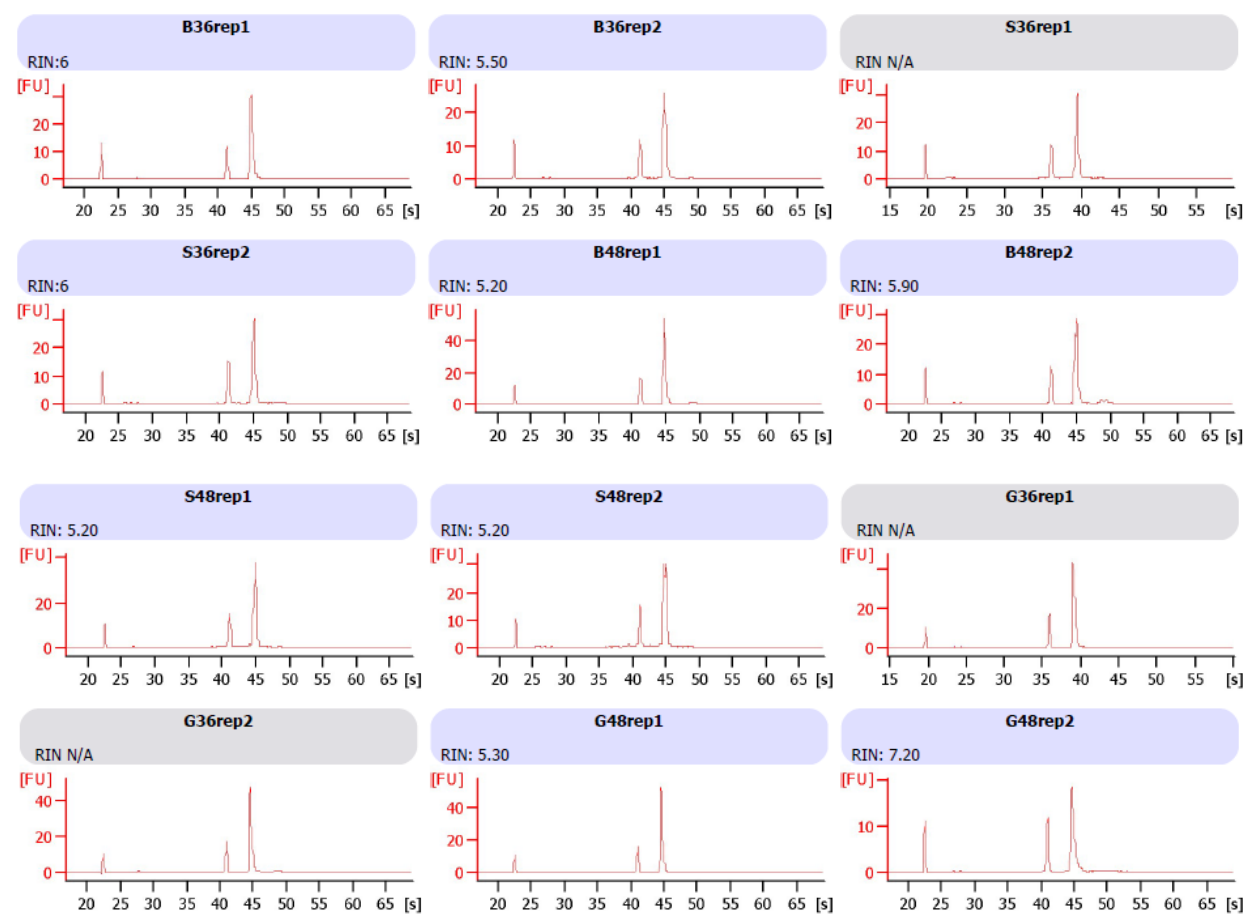

Figura 12: Avaliação da integridade do RNA total de A. terreus pelo Bioanalyzer (Agilent Technologies). Uns totais de 12 amostras de RNA total representam os tratamentos que foram sequenciados pelo método Illumina Hiseq2500. Cada tratamento foi conduzido em duplicata: A. terreus cultivado em bagaço de cana no tempo de 36 horas, A. terreus cultivado em bagaço de cana no tempo de 48 horas, A. terreus cultivado em casca do grão da soja no tempo de 36 horas, A. terreus cultivado em casca do grão da soja no tempo de 48 horas, A. terreus cultivado em glicose no tempo de 36 horas, A. terreus cultivado em glicose no tempo de 48 horas. A: Separação electroforética das amostras de RNA total pelo Bioanalyzer. A canaleta L corresponde ao marcador de tamanho do RNA e as canaletas numeradas representam as amostras de RNA total de A. terreus. As duas bandas intensas correspondem ao rRNA 28S e 18S. B: os picos correspondem a intensidade de fluorescência medidos durante a electroforese das amostras, com o eixo $\mathrm{X}$ representando o tamanho dos fragmentos de RNA em nucleotódeos e o eixo Y corresponde as unidades de fluorescência. 


\subsection{2- Construção da biblioteca de cDNA e Sequenciamento Illumina HiSeq2500.}

As 24 bibliotecas de cDNA sequenciadas (dois canais do flowcell da Illumina, 12 bibliotecas de cDNA por canal) gerou uma média total de 2,7 GB por biblioteca, com um total de 652,78 milhões de leituras. Mais de $80 \%$ das leituras exibiram uma qualidade de $\mathrm{Q}>=30$ (tabela 4).

Tabela 4: Resumo dos dados estatísticos do sequenciamento das bibliotecas de cDNA do A. terreus cultivadas em diferentes fontes de carbono (bagaço de cana de açúcar, casca do grão da soja e glicose). Os dados mostram a concentração de RNA de cada biblioteca, a integridade (280/260 e RIN), o numero de dados gerados por biblioteca (Yield), o número de leituras gerados das bibliotecas (\# Reads) e a média do valor de qualidade das leituras $(\mathrm{Q}>=30)$.

\begin{tabular}{|c|c|c|c|c|c|c|}
\hline Biblioteca & Conc. $(\mu \mathrm{g} / \mu \mathrm{l})$ & $280 / 260$ & RIN & $\begin{array}{l}\text { Yield } \\
\text { (GB) }\end{array}$ & $\begin{array}{l}\text { \# Reads } \\
\text { (Millions) }\end{array}$ & $\%$ Reads $Q>=30$ \\
\hline B36rep1_1 & 1,4 & 1,83 & 6.0 & 2,97 & 29,67 & 81,03 \\
\hline B36rep2_1 & 1,55 & 1,79 & 5.50 & 3,06 & 30,56 & 80,97 \\
\hline S36rep1_1 & 1,3 & 1,94 & N/A & 2,77 & 27,66 & 80,92 \\
\hline S36rep2_1 & 0,606 & 1,93 & 6.0 & 2,86 & 28,63 & 80,64 \\
\hline B48rep1_1 & 1,37 & 1,75 & 5.20 & 2,41 & 24,08 & 80,86 \\
\hline B48rep2_1 & 1,5 & 1,8 & 5.90 & 2,41 & 24,14 & 81,54 \\
\hline S48rep1_1 & 0,588 & 1,93 & 5.20 & 2,49 & 24,85 & 80,82 \\
\hline S48rep2_1 & 0,848 & 1,93 & 5.20 & 3,16 & 31,56 & 81 \\
\hline G36rep1_1 & 1,3 & 1,8 & N/A & 2,58 & 25,78 & 79,9 \\
\hline G36rep2_1 & 1,47 & 1,79 & N/A & 2,29 & 22,86 & 80,11 \\
\hline G48rep1_1 & 1,68 & 1,8 & 5.30 & 2,67 & 26,72 & 80,38 \\
\hline G48rep2_1 & 1,45 & 1,81 & 7.20 & 2,96 & 29,55 & 81,2 \\
\hline B36rep1_2 & 1,4 & 1,83 & 6.0 & 2,91 & 29,11 & 82,26 \\
\hline B36rep2_2 & 1,55 & 1,79 & 5.50 & 3,08 & 30,75 & 82,24 \\
\hline S36rep1_2 & 1,3 & 1,94 & N/A & 2,8 & 27,98 & 82,17 \\
\hline S36rep2_2 & 0,606 & 1,93 & 6.0 & 2,88 & 28,84 & 81,91 \\
\hline B48rep1_2 & 1,37 & 1,75 & 5.20 & 2,4 & 23,98 & 82,15 \\
\hline B48rep2_2 & 1,5 & 1,8 & 5.90 & 2,41 & 24,09 & 82,81 \\
\hline S48rep1_2 & 0,588 & 1,93 & 5.20 & 2,51 & 25,1 & 82,08 \\
\hline S48rep2_2 & 0,848 & 1,93 & 5.20 & 3,15 & 31,47 & 82,29 \\
\hline
\end{tabular}




\begin{tabular}{lllllll}
\hline G36rep1_2 & 1,3 & 1,8 & N/A & 2,55 & 25,48 & 81,21 \\
\hline G36rep2_2 & 1,47 & 1,79 & N/A & 2,33 & 23,29 & 81,47 \\
\hline G48rep1_2 & 1,68 & 1,8 & 5.30 & 2,67 & 26,66 & 81,65 \\
\hline G48rep2_2 & 1,45 & 1,81 & 7.20 & 3 & 29,97 & 82,45
\end{tabular}

\subsubsection{Análise dos genes expressos por biblioteca de cDNA}

O genoma de referência do A. terreus (NIH 2624) possui 10.406 genes. O mapeamento das leituras no presente trabalho contra o genoma de referência identificou um total de mais de 8.000 genes por bibliotecas de cDNA. Para o tratamento com glicose foi um total de 8.812 genes, para o tratamento com bagaço de cana de açúcar 8.837 genes e para o tratamento com casca do grão da soja um total de 8.799 genes. Os resultados refletem a boa qualidade do mRNA, possibilitando uma cobertura alta de leituras pelo sistema de Illumina Hiseq2500, com um número alto de genes alinhados no genoma de referência.

A figura 13 (Heatmap) mostra a expressão do total de mais de 8000 genes de cada tratamento sequenciado. O Heatmap utiliza os parâmetros estatísticos pvalue $<0,01$ e as comparações entre os níveis de expressão em log2foldChange. As cores representam os níveis de expressão, sendo vermelho para superexpressos e azul para subexpressos. Foi possível verificar que os dados da expressão formaram dois grupos distintos: um grupo foi dos tratamentos bagaço de cana de açúcar e casca do grão da soja contra a glicose nos tempos de 36 e 48 horas. Este grupo permaneceu à direita do Heatmap ficando com a cor mais intensa devido a uma maior quantidade de genes superexpressos ou subexpressos. O outro grupo que ficou à esquerda do Heatmap foi dos tratamentos bagaço de cana de açúcar contra ele mesmo e contra a casca do grão da soja e vice-versa e da glicose contra ela mesma nos tempos de 36 e 48 horas, permanecendo com uma coloração mais fraca, o que mostra uma menor intensidade de expressão.

Pode-se inferir que alguns grupos de genes são reprimidos na presença da casca do grão da soja quando comparado com bagaço de cana e são induzidos no tratamento oposto.

O tempo não foi um fator relevante na expressão diferencial dos genes nos diferentes tratamentos. Ao analisar o mesmo tratamento nos dois tempos (36 e 48h) não houve uma mudança significativa de genes induzidos ou reprimidos. Já a fonte de carbono foi mais 
determinante na expressão dos genes. Existem grupos de genes que são induzidos ou reprimidos exclusivamente em uma determinada fonte de carbono.

Os dados mais expressivos de expressão gênica foram para os tratamentos bagaço de cana de açúcar e casca do grão da soja quando comparado com os dados de glicose. Esses são os dados que apresentam coloração mais intensa no Heatmap. Com o resultado do Heatmap pode-se observar uma visão global da expressão de todos os genes sequenciados e a partir disso diferentes análises foram realizadas com o objetivo de caracterizar o transcritoma do $A$. terreus.

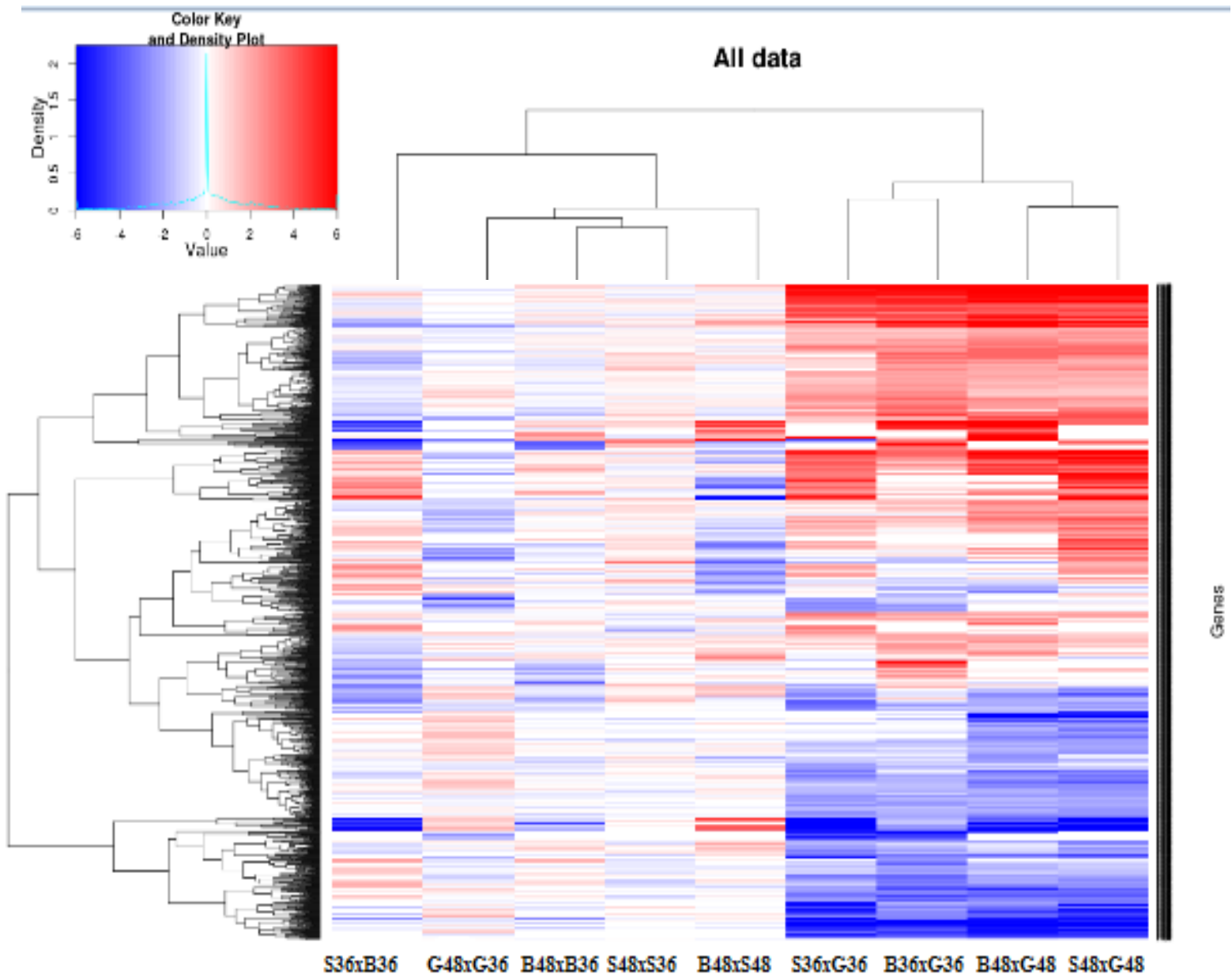

Figura 13: Heatmap dos genes expressos de A. terreus quando cultivado em bagaço de cana de açúcar e casca do grão da soja comparado a glicose. Os dados de cada tratamento foram avaliados de acordo com os valores de $\log 2$ foldChange e padj <0,01. S36xB36- tratamento soja 36 horas contra o tratamento bagaço 36 horas; G48xG36- tratamento glicose 48 horas contra glicose 36 horas; B48xB36- tratamento bagaço 48 horas contra bagaço 36 horas; S48xS36- tratamento soja 48 horas contra soja 36 horas; B48xS48- tratamento bagaço 48 horas contra soja 48 horas; S36xG36- tratamento soja 36 horas contra glicose 36 horas; B36xG36- tratamento bagaço 36 horas contra glicose 36 horas; B48xG48- tratamento bagaço 48 horas contra glicose 48 horas; S48xG48tratamento soja 48 horas contra glicose 48 horas. 
A transcritomica de Aspergillus aplicada à busca de genes envolvidos na produção e regulação de enzimas hidrolíticas tem sido foco das indústrias de enzimas. No final dos anos 90, os primeiros estágios da transcritômica de Trichoderma e Aspergillus focaram no sequenciamento em larga escala de ESTs (Expressed Sequenced Tags). Em 2002, Chambergo et al. iniciou os estudos de transcritômica de $T$. reesei em relação as regulações glicosedependentes, sendo identificados 1.151 unigenes dentre 2.835 ESTs. Estudo semelhante foi realizado para Aspergillus oryzae, onde cerca de 2.000 ESTs selecionados e experimento de microarranjo mostraram que os transcritos sob tratamento suplementado com glicose são altamente dependentes da via glicolítica (Maeda et al., 2004).

Desde então, estudos têm contribuído para o total de ESTs depositados no banco de dados Genbank do NCBI, onde espécies do Gênero Aspergillus promissoras para a produção de enzimas hidrolíticas possuem cerca de, 19.830 ESTs de A. oryzae, 16.394 de A. nidulans 14.195 de A. niger e 10.415 de A. terreus. Entretanto, para espécies de Trichoderma o número de ESTs disponível no Genbank é mais expressivo considerado a importância biotecnológica desse Gênero. T. reesei possui 44.966 ESTs, seguido por T. virens com 35.475 ESTs, T. atroviride com 35.125 ESTs, T. harzianum com 19.914 ESTs e T. longibrachiatum com 1.799 ESTs.

Os resultados da análise do transcritoma do A. terreus mostram a capacidade que o fungo tem em expressar diferentes genes com atividade celulolítica e hemicelulolíticas quando crescido em resíduos agroindustriais. A capacidade de induzir a secreção de enzimas hidrolíticas foi claramente observada no presente estudo com a espécie A. terreus e a regulação da produção de diferentes hidrolases nas duas fontes de carbono (bagaço de cana e casca do grão da soja) tiveram algumas variações. Isto pode ser explicado devido ao fato das duas fontes de carbono ser consideradas complexas com uma composição química diferente.

Como a produção em grandes quantidades de enzimas extracelulares é um processo que consome energia, a regulação dos genes que codificam as enzimas que degradam a parede celular vegetal garante que essas enzimas sejam produzidas apenas sob condições em que o fungo necessita utilizar polímeros das plantas como fonte de energia e de carbono. É necessária uma ação sinérgica das enzimas para a degradação dos componentes da parede celular das plantas e assim, a produção de muitas enzimas é coordenadamente regulada (Margolles-Clark et al., 1997).

O heat map (figura 13) demonstrou um alto nível de expressão de genes nos tratamentos com bagaço de cana de açúcar e casca do grão da soja quando comparado a 
glicose. O agrupamento hierárquico de genes com alta e baixa expressão nas duas fontes de carbono evidencia que a expressão de alguns grupos de genes ocorre de forma semelhante nos dois tratamentos. Tian et al (2009) relataram um total de 769 genes de Neurospora Crassa com aumento significativo no nível de expressão entre as quatro amostras cultivadas na gramínea Miscanthus em comparação com as amostras em sacarose. Os genes mais expressos codificam proteínas previstas para estar relacionadas com a degradação da parede celular vegetal. O genoma de fungos filamentosos tem um grande número de glicosil hidrolases (200), com números variados de celulases preditas, 10 em T. reesei e 60 em Podospora anserina (Tian et al., 2009).

Sabe-se que o custo de celulases e hemicelulases contribuem substancialmente para o preço do bioetanol, com isso, novos estudos visando à compreensão e melhoria da eficiência e produtividade destas enzimas é de primordial importância. Os fungos T. reesei e A. niger são conhecidos por produzir um largo espectro de enzimas hidrolíticas. Essas enzimas possuem aplicação numa variedade de produtos industriais, tais como, alimentação, ração animal, polpa, papel e indústria têxtil.

O genoma de A. niger e T. reesei possui 14.600 e 9.129 genes, respectivamente, sendo cerca de 200 e 170 envolvidos na degradação de polissacarídeos. Em A. niger as principais celulases e hemicelulases são co-reguladas pela mesma molécula indutora (D-xilose), mas o mecanismo de indução em $T$. reesei é mais diversificado. Pelo menos quatro moléculas indutoras diferentes (D-xilose, xilobiose, soforose e lactose) têm sido descritas, mas nenhuma delas tem o potencial de provocar a expressão de todas as principais celulases e hemicelulases (Stricker et al., 2006). Geralmente, considera-se que os genes de celulases estão coordenadamente expressos, mas há diferenças em relação ao tempo de indução e / ou a extensão entre certos genes em resposta a indutores diferentes (Foremam et al., 2003).

O estudo de Tian e colaboradores (2009) elaboraram um modelo de desconstrução da parede celular vegetal em Neurospora crassa e esse modelo é dividido em duas etapas: indução e utilização. Na etapa de indução enzimas extracelulares são expressas em níveis baixos geram metabólitos que sinalizam o fungo para aumentar drasticamente o nível de expressão de genes que codificam enzimas que degradam a parede celular da planta. Durante as fases de utilização enzimas extracelulares e transportadores específicos para a translocação de produtos que degradam a parede celular e permitem que $N$. crassa utilize material da célula vegetal para o seu crescimento. Algumas proteínas extracelulares podem gerar metabólitos que modulam genes de celulases e hemicelulases durante a fase de utilização. 
Visto que os fungos potencialmente lignocelulolíticos produzem enzimas hidrolíticas de acordo com a fonte de carbono utilizada, estudos têm focado na compreensão da dinâmica transcricional desses fungos voltada para a hidrólise da parede celular de resíduos agroindustriais. Análise da expressão gênica em espécies de fungos lignocelulolíticos cultivadas em diferentes substratos de biomassa vegetal como única fonte de carbono permite a identificação de mecanismos conservados e específicos utilizados na degradação microbiana de diversos resíduos da parede celular, provenientes de diferentes espécies de plantas (Roche et al., 2015).

Visando o entendimento de como os genes que codificam enzimas hidrolíticas de $A$. niger são influenciados pelo bagaço da cana-de-açúcar, baseado em análise de microarranjo de 3.700 genes de A. niger, 18 genes que codificam celulases tiveram aumento de expressão em resposta ao bagaço da cana em comparação com a frutose. Resposta semelhante ocorreu com 21 genes que codificam hemicelulases. Sete genes que codificam transportadores preditos também tiveram um aumento de expressão em resposta ao bagaço e repressão na presença da glicose, sugerindo que esses genes sejam transportadores de xilose (De Souza et al, 2014).

\subsubsection{Caracterização de ontologias dos genes (GO) de A. terreus BLU24 cultivado sob diferentes tratamentos}

O elevado número de sequências geradas no presente trabalho permite uma visão global dos diferentes processos biológicos que ocorrem no organismo em um dado momento (36 e 48h). A classificação destas sequências permite a análise dos genes que podem estar envolvidos na degradação da biomassa. Uma forma de analisar esses dados é por meio dos GO termos (Gene ontology) que é um sistema de classificação internacional normalizado que descreve as propriedades dos genes e de seus produtos em qualquer organismo. A base de dados GO compreende de três ontologias: função molecular, componente celular e processo biológico. Quando analisados de acordo com os processos biológicos, a maioria das anotações foi classificada em processo biosintético da arginina, processo biosintético do ácido graxo, transporte de carboidrato e processo catabólico de xilana. Os processos biológicos que tiveram uma presença maior de tratamentos foram: processo catabólico de xilana, processo catabólico de celulose, processo catabólico de pectina e transporte de carboidrato, muitos 
envolvidos na degradação da biomassa (Figura 14). No que diz respeito aos componentes celulares, genes envolvidos em componentes integrais da membrana e espaço extracelular foram os mais abundantes. Para os genes relacionados com o espaço extracelular os tratamentos com CGS e BCA obtiveram um resultado significativo (Figura 15). Já para as funções moleculares, genes envolvidos com atividade oxoacil sintase, atividade oxidoredutase e atividade endo 1,4 beta manosidase foram as que apresentaram um maior número de sequências. As funções moleculares que obtiveram um maior número de tratamentos relacionados foram as atividades de manosidase, celulase, transporte transmembrana e ligação a celulose (Figura 16). 


\section{Biological Process}

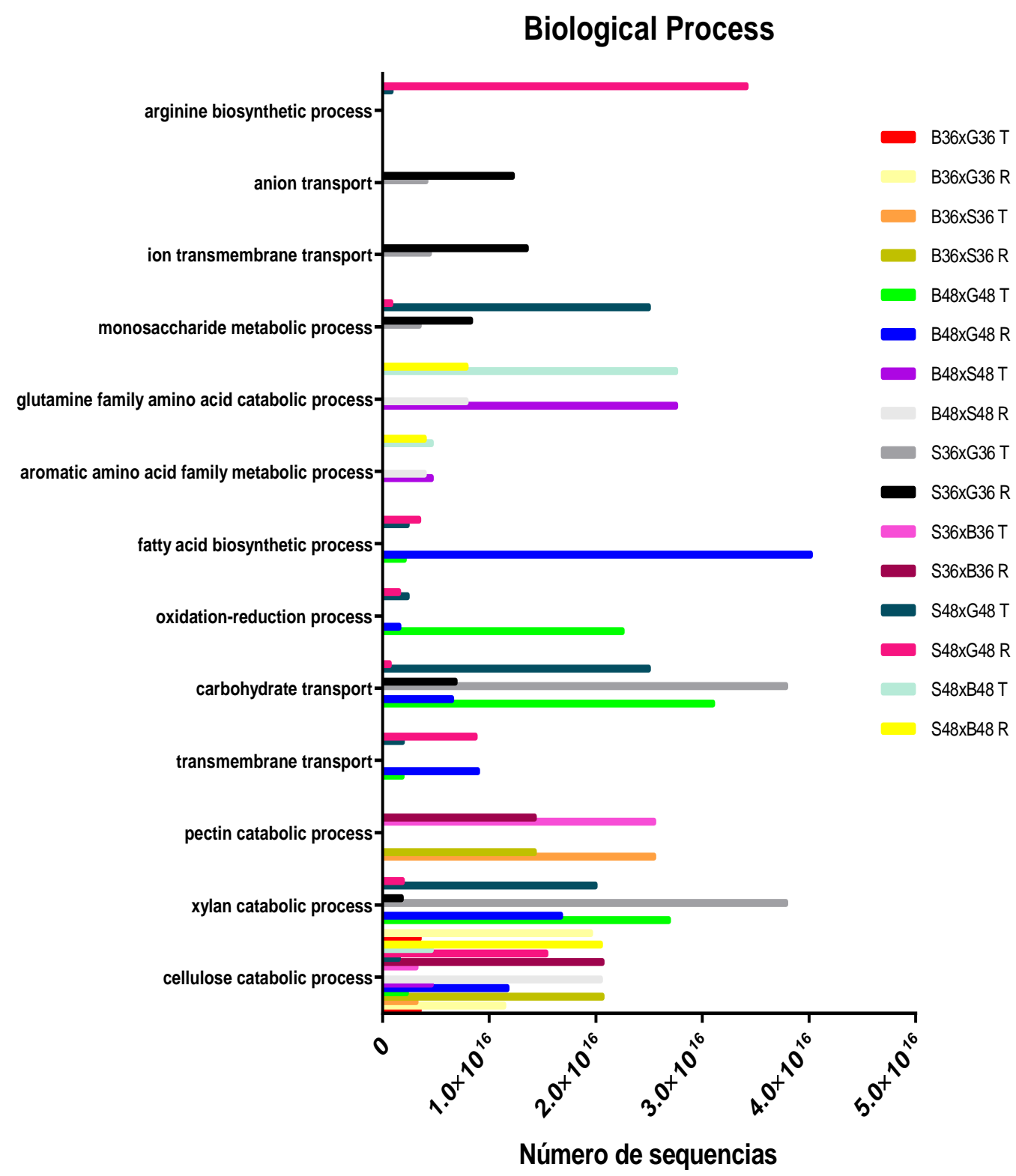

Figura 14: Distribuição dos processos biológicos dos dados do transcritoma do A. terreus BLU24. A letra T representa os dados dos tratamentos e a letra $\mathrm{R}$ representa os dados do genoma de referência. $\mathrm{P}<0,01$ 


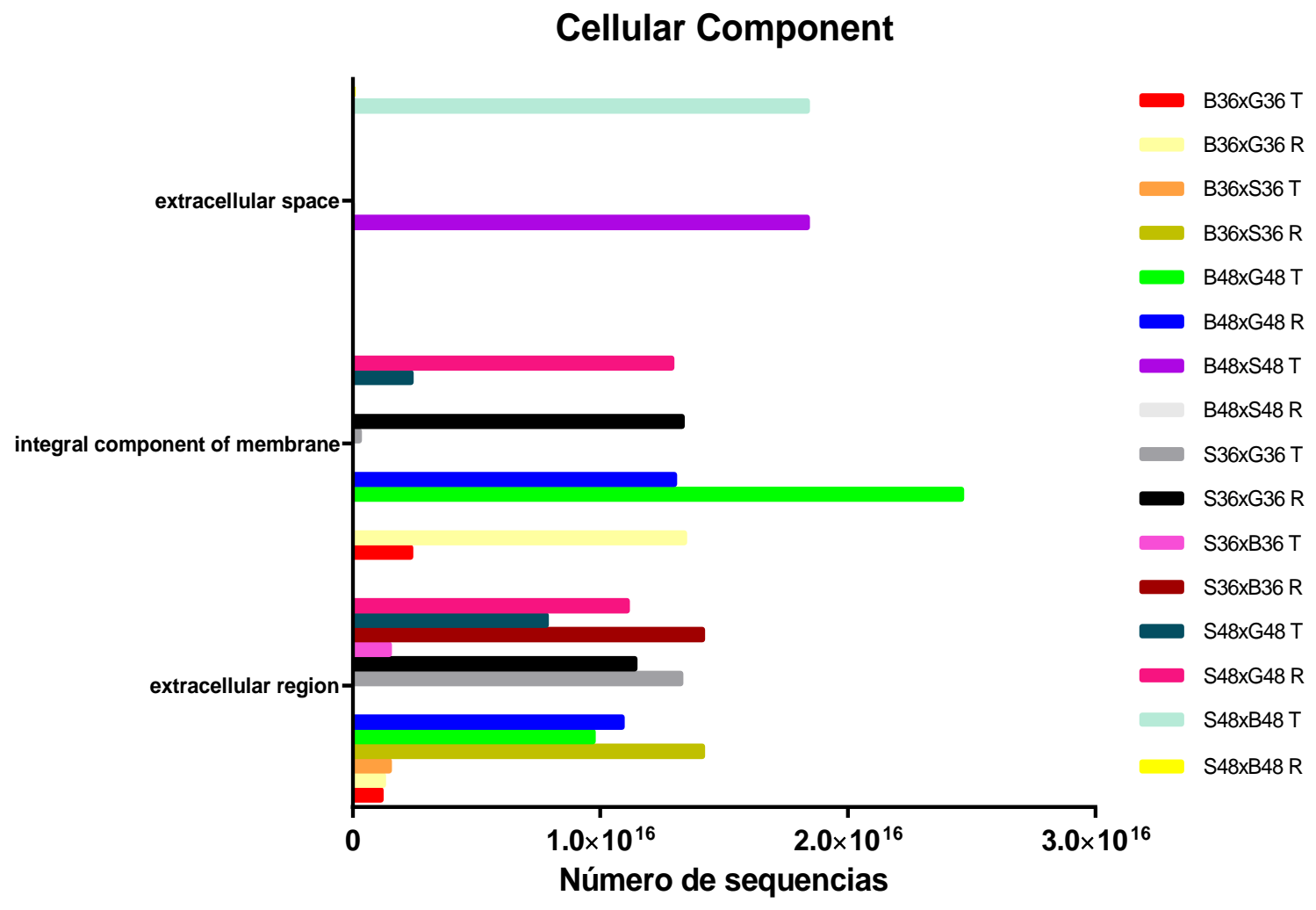

Figura 15: Distribuição dos componentes celulares dos dados do transcritoma do A. terreus BLU24. A letra T representa os dados dos tratamentos e a letra $\mathrm{R}$ representa os dados do genoma de referência. $\mathrm{P}<0,01$ 
Molecular Function

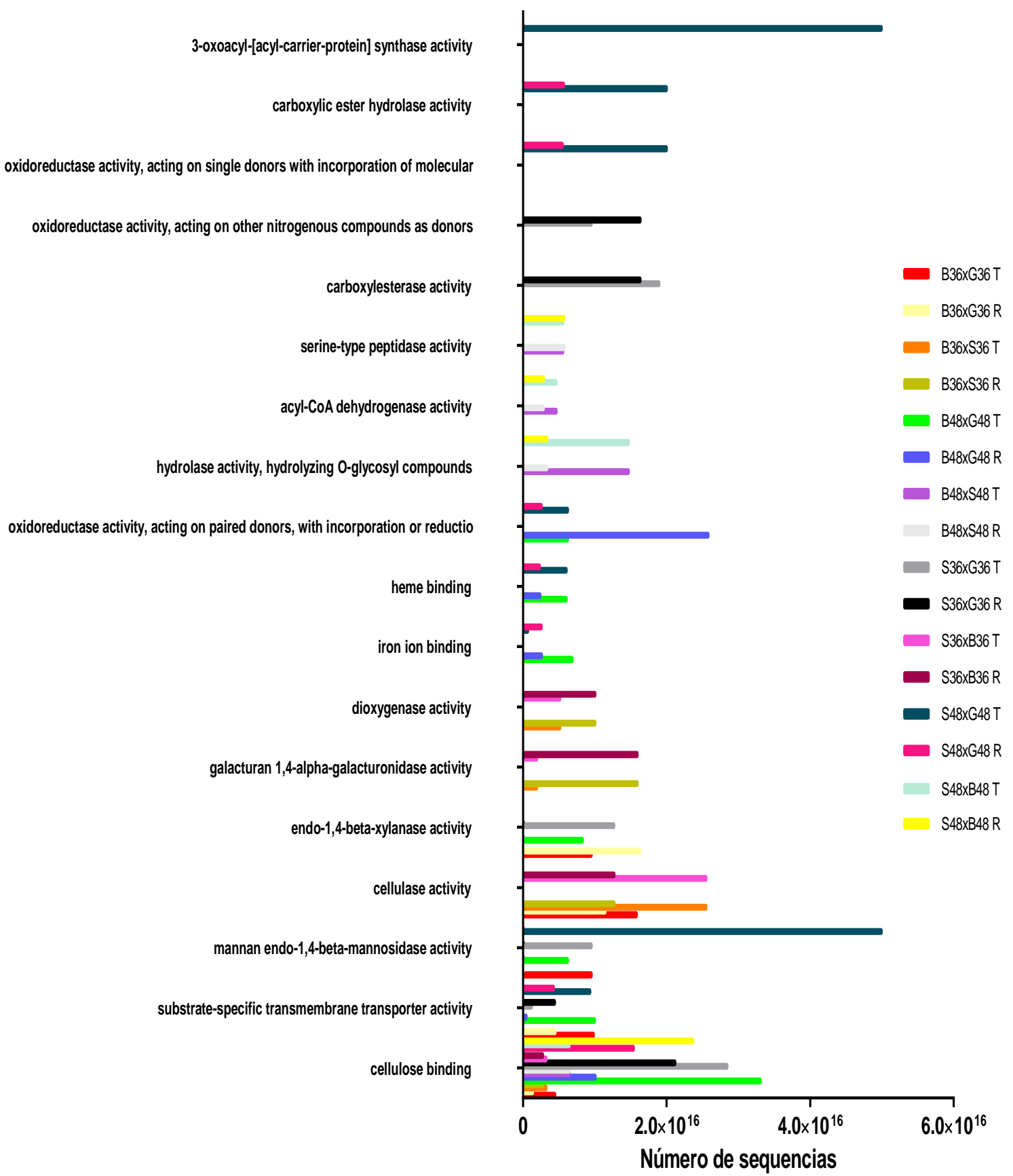

Figura 16: Distribuição das funções moleculares dos dados do transcritoma do A. terreus BLU24. A letra T representa os dados dos tratamentos e a letra $\mathrm{R}$ representa os dados do genoma de referência. $\mathrm{P}<0,01$ 
Foram realizadas análises individuais para cada tratamento em relação a ontologia dos genes, sendo que os quatro tratamentos contrastantes (B36xG36, B48XG48, S36xG36, S48xG48) estão representados por gráficos nas figuras abaixo. No tratamento bagaço comparado a glicose no tempo de 36 horas (B36xG36) (figura 17) a abundância de sequências no tratamento foi maior do que os dados do genoma de referência. Os termos GO que obtiveram um maior número de sequências foram os relacionados com o componente celular: região extracelular e componente integral de membrana. Já os termos relacionados com a degradação da biomassa vegetal quase não foram representados pelo genoma de referência. As análises dos GO com maior número de sequências no tempo de 48 horas para bagaço de cana de açúcar e casca de soja (figuras 18 e 20) foram os mesmos: transporte transmembrana (processo biológico), processo de oxidação-redução (processo biológico), região extracelular e membrana integral (componente celular). Também é possível visualizar com as análises de GO que após dois dias de cultivo o fungo expressa uma maior diversidade de genes relacionados aos termos GO quando comparado ao tempo de 36 horas. As análises de GO para os termos relacionados com processo biológico e função molecular evidenciam que os dados relevantes, que aparecem em todos os tratamentos contrastantes e que estão relacionados com a degradação da parede celular vegetal ocorrem de forma presente também no termo de componente celular relacionado com a região extracelular, visto que as enzimas deverão ser secretadas para o espaço extracelular para degradar o bagaço de cana de açúcar e a casca do grão da soja. A atividade de endo-1,4- $\beta$-manosidase não teve um número significativo de sequências no genoma de referência em nenhum dos tratamentos. Esta enzima catalisa a hidrólise aleatória de ligações manosidicas $\beta$ - 1,4 em mananas, galactomananas e glucomananas. 


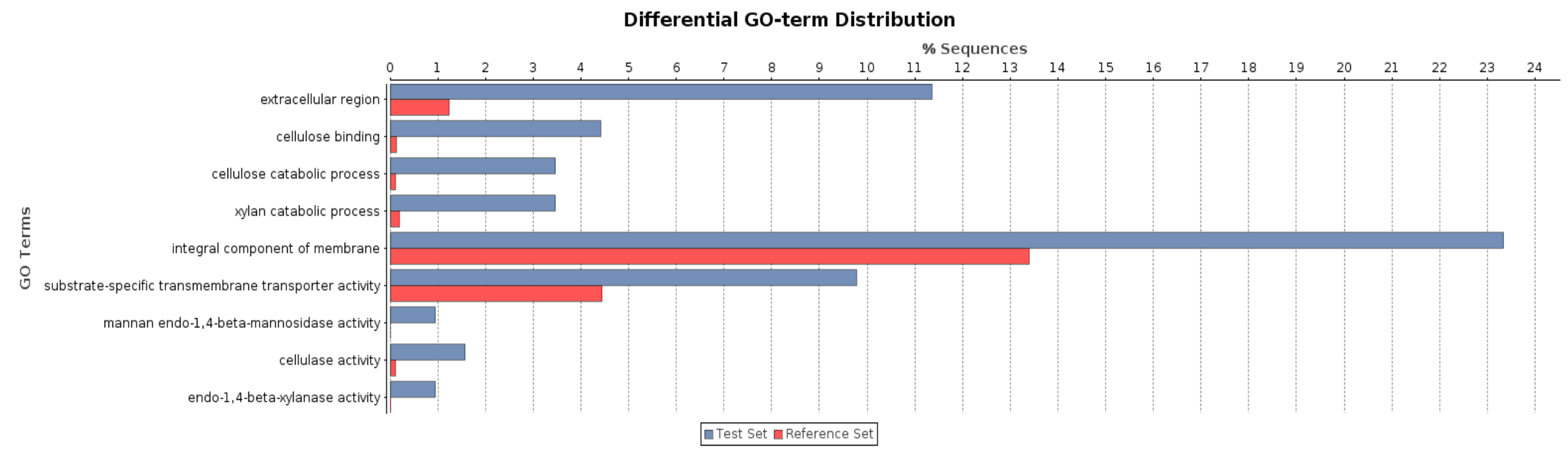

Figura 17: Distribuição diferencial de termos GO no tratamento B36xG36 (bagaço de cana de açúcar comparado com glicose no tempo de 36 horas). Test set são os dados do tratamento e Reference Set são os dados do genoma de referência. 


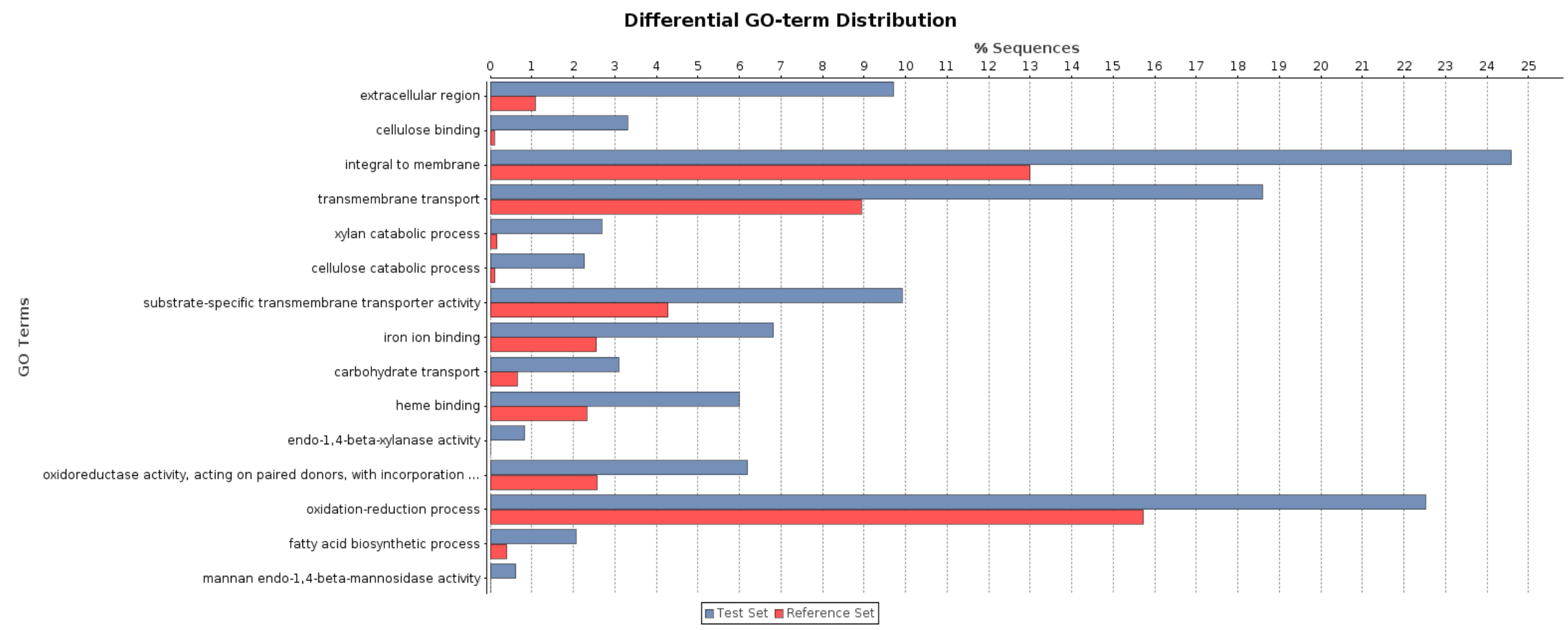

Figura 18: Distribuição diferencial de termos GO no tratamento B48xG48 (bagaço de cana de açúcar comparado com glicose no tempo de 48 horas). Test set são os dados do tratamento e Reference Set são os dados do genoma de referência. 


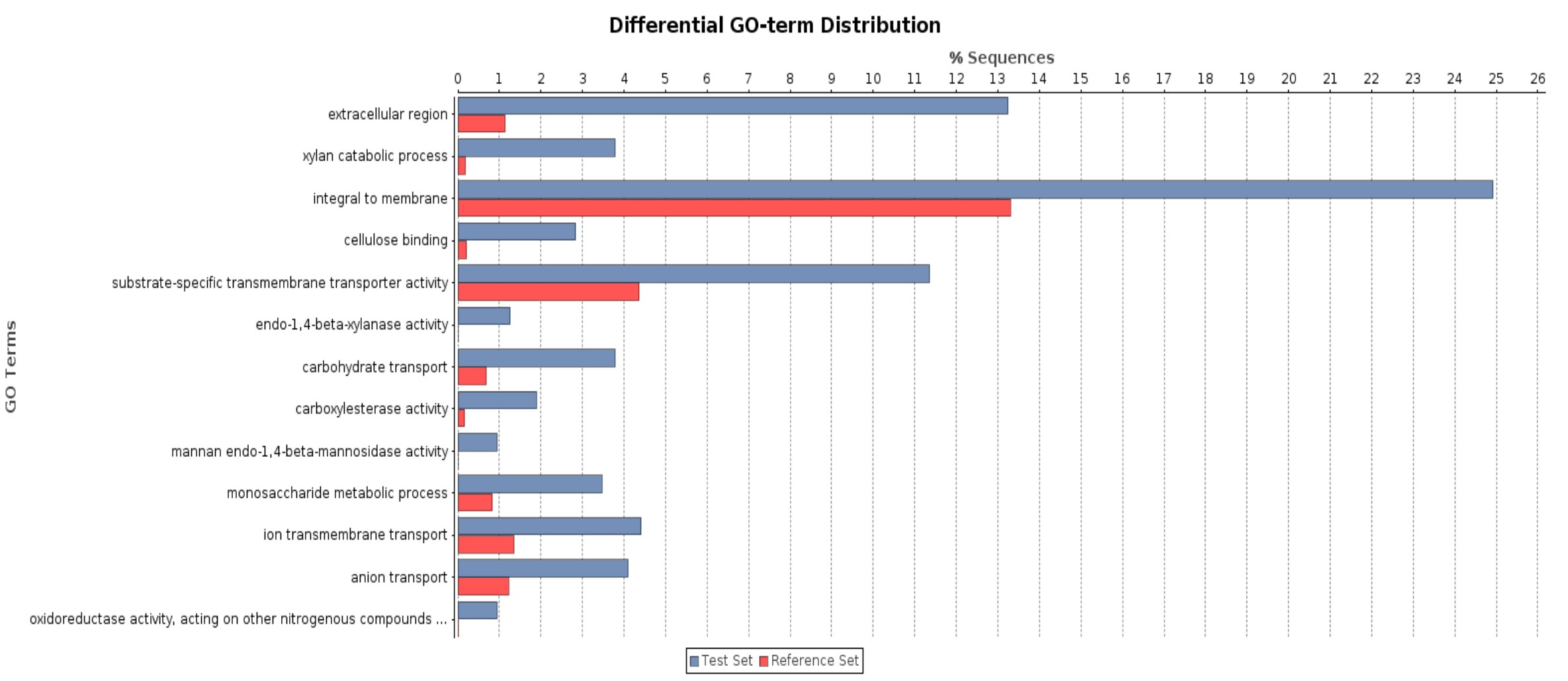

Figura 19: Distribuição diferencial de termos GO no tratamento S36xG36 (casca do grão da soja comparado com glicose no tempo de 36 horas). Test set são os dados do tratamento e Reference Set são os dados do genoma de referência. 


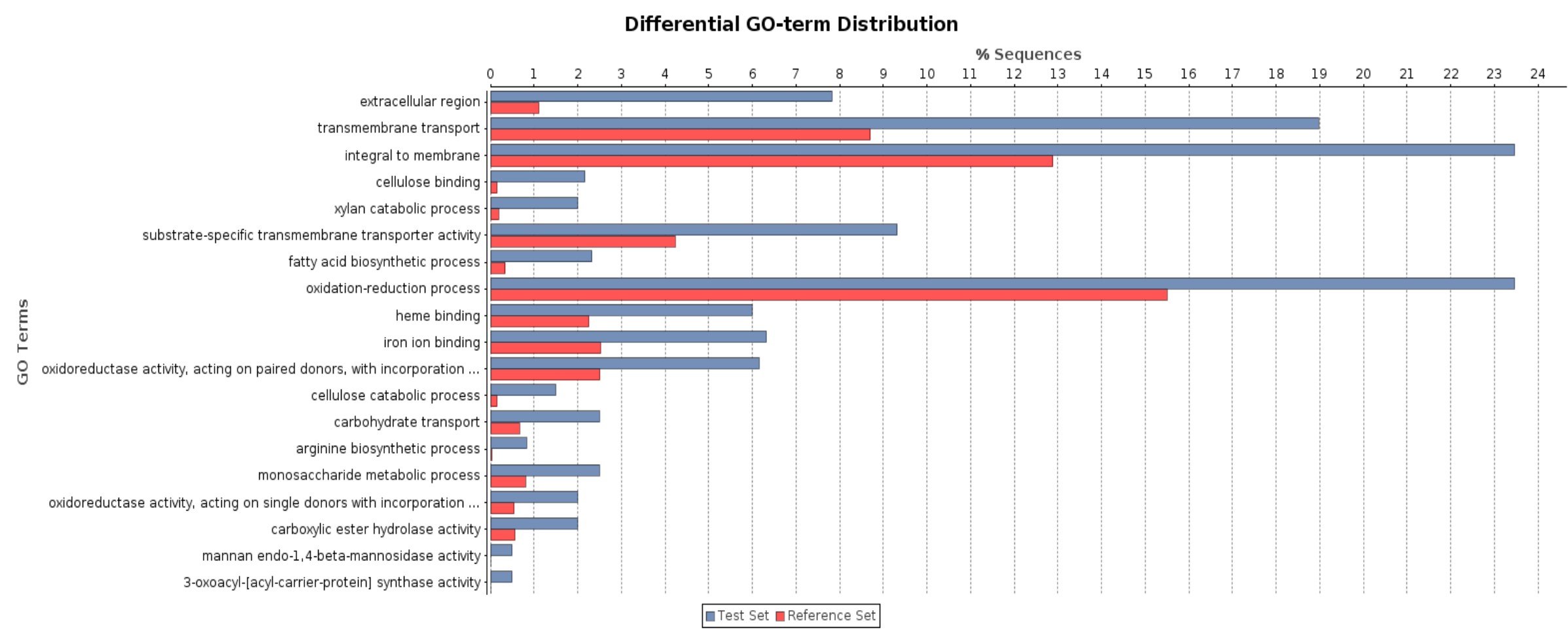

Figura 20: Distribuição diferencial de termos GO no tratamento S48xG48 (casca do grão da soja comparado a glicose no tempo de 48 horas). Test Set são os dados do tratamento e Reference Set são os dados do genoma de referência. 


\subsubsection{Análises de superexpressão e subexpressão de genes de $A$. terreus classificados dentro da família: CAzy, fatores de transcrição, oxidoredutases e permeases.}

As análises dos dados apresentados por meio de gráficos volcanos permitiu observar genes superexpressos e subexpressos nos diferentes tratamentos, com a classificação para genes CAZy, fator de transcrição, permease e oxidoredutase.

Hidratos de carbono são amplamente distribuídos na natureza, onde medeia uma infinidade de funções biológicas, tais como, fonte de carbono, moléculas estruturais, mediadores de reconhecimento intra e intercelular dentro de um organismo ou entre organismos. A diversidade do complexo dos hidratos de carbono é controlada por um painel de enzimas envolvidas na sua montagem (glicosiltransferases) e sua degradação (glicosil hidrolases, polissacarídeo liases e as esterases) coletivamente designadas como enzimas carboidratos-ativo (CAZymes) (Lombard et al., 2013). Devido a importância destas enzimas (CAZymes) esta família foi escolhida para uma análise mais robusta a partir do transcritoma do fungo A. terreus BLU24.

Outra família de genes que codificam fatores de transcrição também foi escolhida para esta análise vista a sua importância para o desenvolvimento do fungo. Fatores de transcrição (TFs) são conhecidos por estarem envolvidos nas vias de transdução de sinais, como uma ligação final entre o fluxo de um sinal e a expressão do gene alvo e pouco se conhece sobre os TFs em fungos filamentosos. Estudos demonstraram que a regulação de celulases ocorre a nível transcricional por isso a importância de conhecer os fatores de transcrição relecionados com a degradação dos substratos utilizados como fonte de carbono. Diante da complexa regulação da produção de um grande número de enzimas e o fato de que muitas destas enzimas com diversas funções são necessárias para a utilização de certos polissacarídeos é necessário aplicar um sistema com abordagem para o mapeamento da rede reguladora dos genes responsáveis pela transcrição e tradução destas enzimas (Coradetti et al., 2012).

Já a família das oxidorredutases é uma grande família de enzimas que catalisam reações de transferência de elétrons, ou seja, reações de oxidoredução. São as desidrogenases e as oxidases. As permeases outra família de enzimas muito importante para o desenvolvimento do fungo, as permeases são enzimas transportadoras que participam do 
processo de difusão transmembranar a favor do gradiente de concentração, atuando sobre aminoácidos e carboidratos (https://www.nlm.nih.gov/cgi/mesh/2011/MB).

Nos tratamentos com bagaço de cana de açúcar e casca do grão da soja comparado a glicose nos tempos de 36 e 48 horas (Figura 21 -A, B, C e D) foi evidenciado uma maior quantidade de genes superexpressos para o grupo de genes CAZy, e uma quantidade menor de permeases e oxidoredutases. Existe também uma distribuição de genes com funções diferentes tanto na posição dos superexpressos quanto para a posição dos subexpressos. Observa-se que além de uma superexpressão nesses tratamentos também ocorre uma grande variedade de genes CAZy. A superexpressão principalmente de glicosil hidrolases nos tratamentos contendo bagaço de cana de açúcar e casca do grão da soja comparado a glicose corrobora com o fato que o fungo na presença de substratos complexos necessita de uma grande quantidade de enzimas atuando sinergicamente para a completa degradação dos substratos e posterior produção de açúcares essenciais para o seu desenvolvimento.

A figura 21A (B36xG36) evidencia pontos em amarelo que estão ao lado direito do gráfico. Caracterizando os genes com maior nível de expressão nesse tratamento $(\mathrm{p}<0,01)$ temos os genes CAZy o qual foi possível conhecer uma endo-1,4-beta-xilanase (GH11) (ATEG_07461) que foi mais de 110 vezes expressa no bagaço do que na glicose e promove a reação de endohidrólise de ligações xilosídicas $\beta$ (1--4) em cadeias de xilana. Observa-se uma endoglucanase (GH12) (ATEG_07420) com expressão aumentada em mais de 150 vezes e é responsável pela reação de endohidrólise de ligações glicosídicas (1---4) em celulose. Por último, observa-se uma acetil xilana esterase (CE) (ATEG_04709) com expressão aumentada em mais de 130 vezes. Em relação aos fatores de transcrição (pontos vermelhos) foi observado o domínio de fator de transcrição específico de fungos (ATEG_10323) com expressão aumentada em mais de 46 vezes. Este domínio é encontrado em um grande número de fatores de transcrição fúngicos, incluindo o ativador transcricional xlnR, GAL4 de levedura, e outras proteínas que regulam a transcrição de uma variedade de processos celulares e metabólicos. Outro fator de transcrição conhecido por CP2 (ATEG_04652) com expressão aumentada em mais de quatro vezes. Proteínas relacionadas com CP2 compreendem uma família de fatores de transcrição de ligação ao DNA que são geralmente ativadores de transcrição e expressos ubiquamente (Rodda et al., 2001). Dentre as oxidoredutases (pontos verdes), as que obtiveram um maior nível de expressão foram: um gene da família de oxidoredutase (NAD binding Rossmann fold oxidoreductase ATEG_00710) com atividade de oxidoredutase glicose-frutose, sua expressão foi aumentada 
em mais de 7 vezes e uma família de cadeia curta de desidrogenase/redutase (SDR) que é uma grande família de enzimas e a maioria são conhecidas por serem oxidoredutases NAD ou NADP dependentes que obtiveram uma expressão aumentada em mais de 6 vezes. Por último, as permeases (pontos azuis) têm uma purina nucleosídio permease (ATEG_08126) que a expressão foi aumentada em mais de 16 vezes.

Comparando os dados da figura $21 \mathrm{~A}$ com a figura $21 \mathrm{~B}$ que é a mesma fonte de carbono em tempos diferentes foi possível observar que a superexpressão foi mais significativa no tempo de 48 horas. Por exemplo, temos uma endo-1,4-beta-xilanase (ATEG_00809) (GH10) com expressão aumentada em mais de 770 vezes no bagaço de cana de açúcar comparado a glicose no tempo de 48 horas. Outro exemplo de superexpressão foi uma celulase da família GH5 (ATEG_05003) com expressão aumentada em mais de 500 vezes. Uma endo-beta-mananase (GH5) (ATEG_08654) cuja expressão foi aumentada em mais de 1000 vezes. Esse aumento significativo do nível de expressão ocorreu principalmente para os genes CAZy e para o tempo de 48 horas tanto no bagaço de cana de açúcar quanto na casca do grão da soja. Analisando os fatores de transcrição da figura 20B, os superexpressos foram um domínio de fator de transcrição específico de fungos (ATEG_05582) que a expressão foi aumentada mais de 6 vezes e um ativador transcricional de $x \ln R$ (ATEG_02432) com expressão aumentada em 5 vezes (ativador transcricional do sistema xilanolítico envolvido na regulação extracelular de genes celulolíticos e xilanolíticos e na regulação das atividades intracelulares de genes catabólicos D-xilose nas vias da pentose em resposta à presença de D-xilose) (http://www.uniprot.org/uniprot/Q0CV52).

A figura 21C representa o tratamento S36xG36, para os genes CAZy temos uma poligalacturanase I da família GH28 (ATEG_04991) que são hidrolases que atuam principalmente em pectato e resultam em mono ou dissacarídeos, sua expressão foi aumentada em mais de 350 vezes. Beta xilanase (GH3) (ATEG_07383) uma classe de enzimas que dregadam o polissacarídeo linear beta -1,4- xilano em xilose, decompondo assim a hemicelulose também teve sua expressão aumentada em mais 350 vezes. Já uma $\alpha$-Larabinofuranosidase (GH62) (ATEG_10071) cuja a expressão foi aumentada em mais de 150 vezes. Já os fatores de transcrição superexpressos foram os mesmos presentes no tratamento com bagaço de cana de açúcar, um domínio de fator de transcrição específico de fungos (ATEG_10323) com expressão aumentada em cinco vezes e uma família de CP2 com aumento de 3,5 vezes (ATEG_04652). Para as oxidoredutases temos uma da super família oxigenase Fe(II) dependente com expressão aumentada em mais de 36 vezes (ATEG_07704) 
e uma família de cadeia curta de desidrogenase/redutase (SDR) oxidoredutases NAD ou NADP dependentes cuja a sua expressão foi aumentada em mais de 13 vezes (ATEG_08184). Já para as permeases ocorreu a superexpressão de uma purina nucleosídeo permease com aumento de 30 vezes (ATEG_08126) e uma alantoato permease (MFS) (ATEG_04642) com aumento de mais de 53 vezes.

A figura 21D evidencia valores altos de expressão de alguns genes relacionados com a degradação da parede celular vegetal. A poligalacturonase I (pectinase-GH28) (ATEG_04491) catalisa a hidrólise aleatória das ligações 1,4- $\alpha$-D-galactosiduronico em pectato e outros galacturonanos. Em fungos como Aspergillus niger, as poligalacturonases estão envolvidas em maceração e no apodrecimento do tecido da planta (http://pfam.xfam.org/family/PF00295). O gene que codifica a poligalacturonase teve a sua expressão aumentada em mais de 377 vezes na casca da soja do que na glicose. O gene da família endo-1,4- $\beta$-manosidase (ATEG_08654) (GH5) teve a sua expressão aumentada em mais de 828 vezes. O mesmo gene ATEG_10323 (fator de transcrição) superexpresso na casca da soja no tempo de 36 horas também surgiu no tempo de 48 horas, porém com aumento da expressão em mais de 16 vezes. Já na família das oxidoredutases temos uma de ligação a NAD (ATEG_04641) que teve a sua expressão aumentada em mais de 176 vezes e uma da superfamília FeII 2OG-oxigenase (ATEG_07704) que foi mais de 134 vezes expressa na casca do grão da soja comparado a glicose. Em bactérias e fungos as enzimas dioxigenase com domínio de Fe (II) $20 \mathrm{O}$ participam da biossíntese dos antibióticos, como a penicilina e cefalosporina (http://pfam.xfam.org/family/PF03171). Um gene da família aminoácido permease (ATEG_04310) teve a sua expressão aumentada em mais de 12 vezes. Esta família são permeases envolvidas no transporte de aminoácidos para a célula. Outra permease superexpressa (mais de 509 vezes) foi uma permease de ácido amino dicarboxilico (ATEG_09721).

Nos demais tratamentos (figura $21 \mathrm{E}, \mathrm{F}, \mathrm{G}, \mathrm{H}$ e I) a expressão permaneceu na faixa de $\log 2$ entre -2 e 2, não ocorrendo uma grande variedade de genes CAZy, fatores de transcrição, permeases e oxidoredutases.

Os dados do transcritoma do A. terreus evidenciou um alto número de genes que codificam enzimas relacionadas com a desconstrução da parede celular vegetal e um grande número desses genes foram superexpressos nas fontes de carbono BCA e CGS quando comparado a glicose. Também temos um alto número de fatores de transcrição, estes dados 
corroboram com a literatura de fungos filamentosos crescidos em diferentes fontes de carbono.

Delmas e colaboradores (2012) relatou a aplicação de RNA-Seq SoLID para analisar o transcritoma em A. niger. O estudo revelou que aproximadamente $19 \%$ do total de mRNA está envolvido na expressão de genes relacionado a enzimas que degradam a parede celular vegetal após 24 horas de exposição a palha de trigo. Esta é uma forte representação de grupos de genes CAZy, uma vez que representam apenas 2,5\% do genoma codificante. As diversas categorias de genes CAZy expressos durante a exposição a palha de trigo reflete a complexidade dos carboidratos presentes no substrato. No entanto é interessante observar que cerca de 65\% do mRNA dos grupos CAZy neste tempo é de genes que codificam apenas 5 famílias de enzimas, GH7, 11, 61 e 62 (celobiohidrolases, xilanases, polissacarídeo monooxigenases e arabinofuranosidases, respectivamente) e CE1 (acetil xilano esterases). Com base na abundância da transcrição, as cinco categorias de enzimas codificadas podem fornecer as atividades necessárias para a degradação da palha. Outro dado importante é que a repressão catabólica por adição de glicose às culturas de palha de trigo exerce forte repressão sobre a expressão de genes CAZy, após 5 horas, o mRNA de genes CAZy é reduzido para apenas $1 \%$ do RNA total.

Estudos mostram que o modelo de indução predominante em sistemas fúngicos propõe que a expressão basal geral de pequenas quantidades de hidrolases inicia a degradação de polissacarídeos complexos, produzindo, assim compostos indutores que provocam a resposta da transcrição completa (Foreman et al., 2003).

O genoma de $A$. niger compreende 31 e 36 genes que codificam celulases e hemicelulases preditas, respectivamente (Hakkinen et al., 2012). Souza e colaboradores (2011) observaram um aumento na expressão (58\%) de genes que codificam celulases e hemicelulases de A. niger crescido em bagaço de cana pré-tratado. Dentre as celulases foi observadas enzimas das famílias GH 1, 3, 5, 6, 7, 12, 61 e 74 e para hemicelulases GH 2, 3, $10,11,12,27,43,51,54,62,67$ e 95.

Hakkinen et al. (2012) recentemente, revisou e ampliou o repertório de CAZys em $T$. reesei a partir de abordagens computacionais e manuais o que resultou em 201 genes que codificam glicosil hidrolases, 22 genes que codificam carboidratos esterases e 5 genes que codificam polissacarídeos liases. Sendo que a maioria dos genes que expressam celulases e hemicelulases caracterizados de T. reesei é regulada pelo tipo de fonte de carbono disponível, a fim de assegurar a produção de enzimas hidrolíticas necessárias para a degradação do 
substrato. Diferentes estudos comparativos do transcritoma de fungos lignocelulolíticos mostram que os genes que codificam enzimas hidroliticas são reprimidos na presença de glicose, e induzidos por compostos derivados do material presente na parede celular vegetal ou seus derivados metabólicos.

Já o estudo de Castro e colaboradores (2014) com T. reesei crescido em celulose, soforose e glicose mostrou enzimas que foram diferencialmente expressas (positivamente) em celulose (23 GH e $2 \mathrm{CE}$ ) e soforose (20 GH e $1 \mathrm{CE}$ ). Este estudo também relatou diferentes CAZy que foram superexpressos em celulose e soforose quando comparado a glicose. De forma interessante, genes de enzimas envolvidas na degradação de xilana, tais como, xilanases (xyn2, xyn3, xyn4), acetil xilana esterase (axe1), xiloglucanase (cel74a), $\alpha$ xilosidase (GH31) e degradação de arabinoxilanos, tais como arabinofuranosidase (ABF1 e ABF2) foram preferencialmente expressos na presença de celulose, mas não em soforose.

As análises dos fatores de transcrição em $T$. reesei que são importantes na regulação dos genes que codificam celulases e hemicelulases relatam alguns que já são bem conhecidos na literatura, como, XYR1, ACE2, e o complexo HAP2/3/5 que são reguladores positivos e reguladores negativos, tais como o ACE1 e o repressor catabólico CRE1, sendo XYR1 o principal ativador transcricional de genes que codificam hidrolases, tais como xyn1, xyn2, bx11, cbh1, cbh2, eg11 (Portnoy et al., 2011).

Em Aspergillus e T. reesei, a expressão de genes de celulase e hemicelulase requer fatores de transcrição fúngicos conservados XlnR/XYR1 (Tian et al., 2009). Embora homólogos xlnR/xyr1 sejam importantes para indução de hemicelulase em espécies como Fusarium e Neurospora crassa, não desempenham um papel importante na expressão dos genes de celulase. Outros ativadores de transcrição específicos do gênero (tais como ECA2 em $T$. reesei) parecem ter alguma especificidade especial para indutores, mas a estirpe de deleção para estes fatores de transcrição ainda induz uma significativa secreção de celulase. Estes resultados sugerem que uma rede complexa de ativadores de transcrição é necessária para indução dos genes e a secreção de celulase e hemicelulase em fungos filamentosos (Aro et al, 2001). 


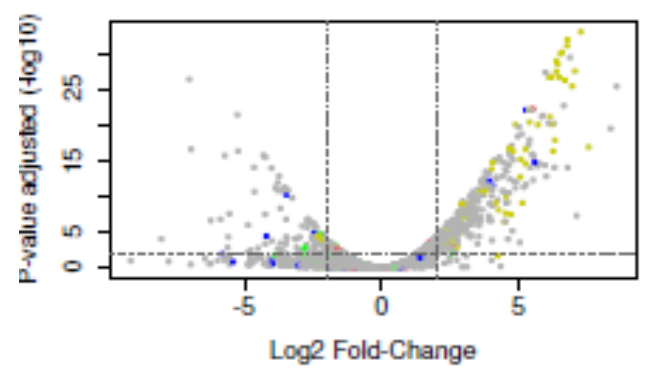

Log2 Fold-Change

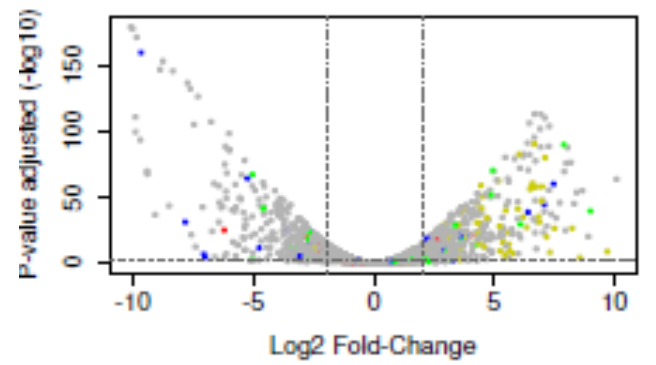

G

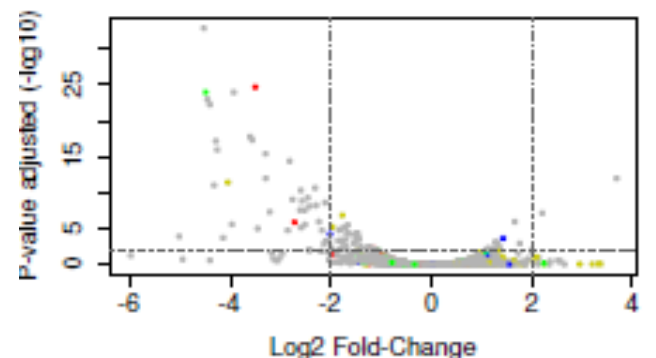

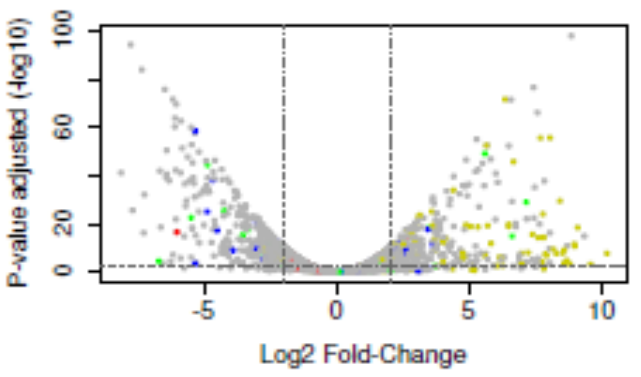

E

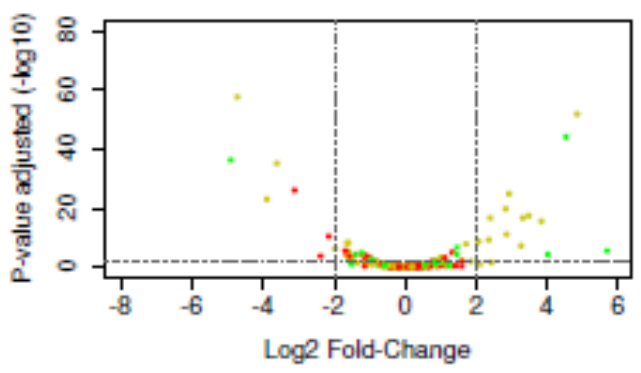

H

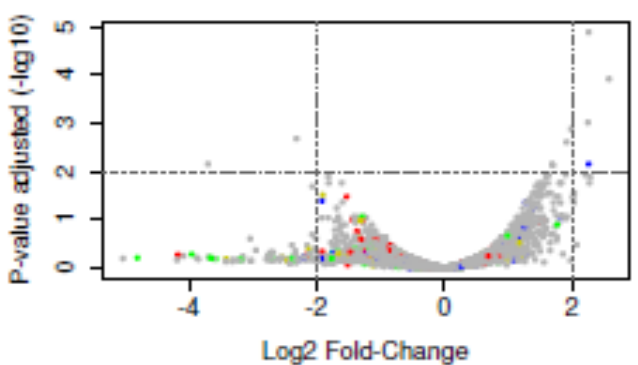

C

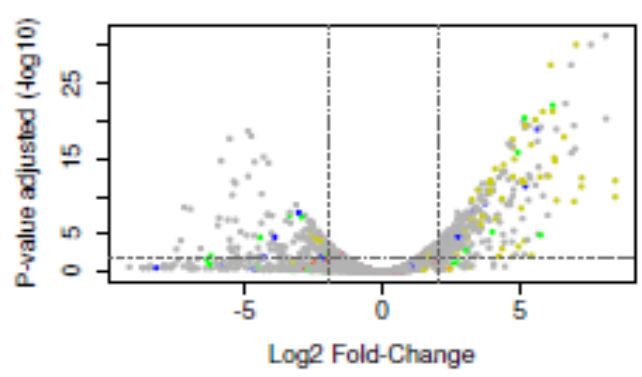

F

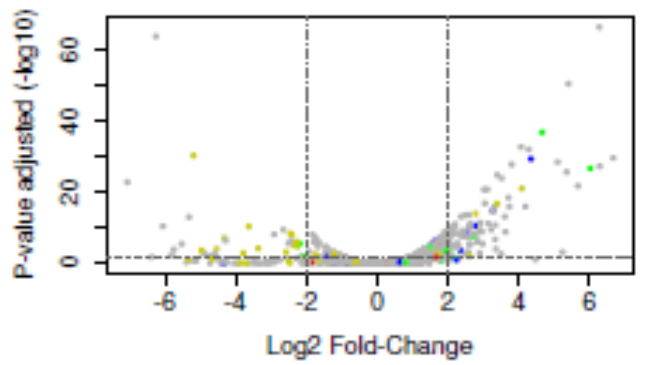

I

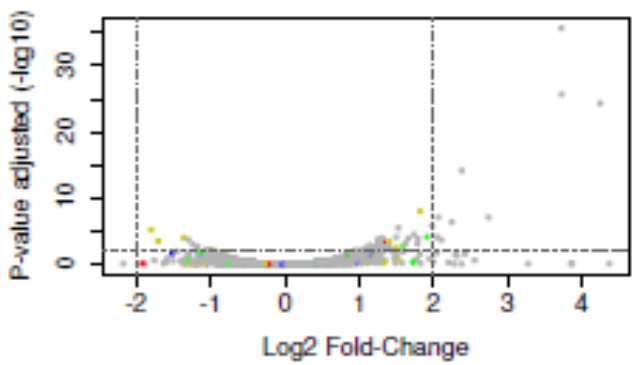

Figura 21: Análise comparativa de dispersão dos genes. Família CAZy (amarelo), fatores de transcrição (vermelho), permeases (verde), oxidoredutases (azul) e genes com outras funções (cinza). A) B36xG36, B) B48xG48, C) S36xG36, D) S48xG48, E) S36xB36, F) S48xB48, G) B48xB36, H) G48xG36, I) S48xS36. Cultura suplementada com bagaço de cana de açúcar (B), suplementada com casca do grão da soja (S), suplementada com glicose (G), cultivo por 36 horas (36) e cultivo por 48 horas (48). 


\subsubsection{Análise dos dez genes diferencialmente expressos em bagaço de cana de açúcar e casca do grão da soja ("Top 10")}

Analisando a tabela abaixo (tabela 5) dos genes "Top 10", no tratamento bagaço de cana de açúcar (tempo 36 horas) o primeiro gene da lista foi uma proteína integral de membrana que teve a sua expressão aumentada em mais de 384 vezes. Dentre os genes Top 10 desse tratamento, a metade está relacionada com a degradação da biomassa vegetal. Temos uma beta xilosidase, uma acetil xilano esterase, uma endo-1,4-beta-xylanase, todas envolvidas na despolimerização da hemicelulose e duas endoglucanases que são envolvidas na despolimerização da celulose. Já no tratamento com bagaço de cana no tempo de 48 horas o foldchange foi superior comparado ao tempo de 36 horas. Por exemplo, o primeiro gene "Top 10" é uma endo-beta-mananase que teve a sua expressão aumentada em mais de 1180 vezes. Neste tratamento mais de $50 \%$ dos genes “Top 10" codificam para proteínas que degradam a biomassa vegetal. Visualizamos uma endo-beta-mannanase e três endoglucanases, ambas relacionadas com a degradação da celulose, e duas endo-1,4-beta-xylanase relacionadas com a degradação da hemicelulose.

Já no tratamento com casca do grão da soja no tempo de 36 horas o primeiro gene “Top 10" que foi expresso mais de 350 vezes na soja, codifica para uma poligalacturonase da família GH28. Dentre os 10 primeiros genes desse tratamento temos 5 genes anotados e relacionados com a degradação da parede celular vegetal. Já no tempo 48 horas o primeiro gene "Top 10" é uma proteína integral de membrana que teve a sua expressão aumentada em mais de 1000 vezes e depois uma endo-beta-mananase que teve a sua expressão aumentada em mais de 820 vezes. O terceiro gene é uma alantoato permease que foi mais de 500 vezes expresso, cujo processo biológico (GO) é transporte transmembrana. O quarto gene é uma cutinase que teve a sua expressão aumentada em mais de 480 vezes. Esta enzima catalisa a hidrólise de cutina, um poliéster que forma a estrutura da cutícula da planta. Neste tempo temos três genes anotados relacionados com a degradação da biomassa vegetal. Nos demais tratamentos têm diferentes proteínas com nível de expressão muito menor, o foldchange não passou de 240, sendo que na maioria dos tratamentos ficou menor que 80. Esta tabela evidencia que a superexpressão dos genes foi superior nos tratamentos contrastantes (B36xG36, B48xG48, S36xG36 e S48xG48). 
Tabela 5: Fold change e anotação dos 10 primeiros genes diferencialmente expressos nos diferentes tratamentos (“Top 10”). B36xG36 e B48xG48 (bagaço de cana comparado a glicose nos tempos de 36 e 48 horas); B36xS36 e B48xS48 (bagaço de cana comparado a casca do grão da soja nos tempos de 36 e 48 horas); S36xG36 e S48xG48 (casca do grão de soja comparado a glicose nos tempos de 36 e 48 horas); B48xB36 (bagaço de cana no tempo 48 horas comparado ao tempo de 36 horas); G48xG36 (glicose no tempo de 48 horas comparado ao tempo de 36 horas; S48xS36 (casca do grão da soja no tempo de 48 horas comparasdo ao tempo de 36 horas). $\operatorname{Padj}<0,01$.

\begin{tabular}{|c|c|c|c|c|c|}
\hline $\begin{array}{l}\text { Gene ID } \\
\text { B36xG36 }\end{array}$ & foldChange & Anotação & $\begin{array}{l}\text { Gene ID } \\
\text { B48xG48 }\end{array}$ & foldChange & Anotação \\
\hline ATEG_02687 & 384,875 & Proteína integral de membrana & ATEG_08654 & 1180,044 & Endo-beta-mannanase \\
\hline ATEG_05874 & 332,294 & Proteína hipotética & ATEG_00809 & 770,627 & Endo-1,4-beta-xylanase \\
\hline ATEG_07383 & 189,076 & Beta-xilosidase & ATEG_02687 & 652,615 & Proteína integral de membrana \\
\hline ATEG_07420 & 156,226 & Endoglucanase & ATEG_04708 & 548,900 & Endoglucanase \\
\hline ATEG_02590 & 139,929 & Proteína secretada rica em cisteína & ATEG_03676 & 511,412 & $\begin{array}{l}\text { Lipase de ligação a celulose } \\
\text { (GDSL) }\end{array}$ \\
\hline ATEG_04709 & 134,241 & Acetil xilano esterase & ATEG_05003 & 503,001 & Endoglucanase \\
\hline ATEG_04708 & 125,084 & Endoglucanase $\mathrm{C}$ & ATEG_08446 & 466,252 & trans-2-enoil-redutase \\
\hline ATEG_01556 & 118,007 & Proteína de membrana (MFS) & ATEG_05416 & 449,772 & Endoglucanase \\
\hline ATEG_01645 & 111,368 & Proteína hipotética & ATEG_04710 & 417,876 & Proteína Hipotética \\
\hline ATEG_07461 & 110,853 & Endo-1,4-beta-xylanase & ATEG_03410 & 411,854 & Endo-1,4-beta-xylanase \\
\hline B36xS36 & & & B48xS48 & & \\
\hline ATEG_07150 & 232,705 & $\begin{array}{c}\text { Desidrogenase / redutase } \\
\text { Proteína de transporte de membrana }\end{array}$ & ATEG_04438 & 134,477 & Proteína predita \\
\hline ATEG_03475 & 84,010 & $(\mathrm{MFS})$ & ATEG_08446 & 76,994 & Proteína predita \\
\hline ATEG_00793 & 82,329 & Proteína sem nome & ATEG_08447 & 67,056 & Trans-2-enoil-redutase \\
\hline ATEG_03467 & 81,466 & Proteína transportadora de ferro & ATEG_08443 & 56,384 & Proteína hipotética \\
\hline ATEG_03476 & 69,294 & Proteína hipotética & ATEG_07150 & 54,046 & Proteína hipotética \\
\hline ATEG_03474 & 67,241 & Citocromo P450 & ATEG_07148 & 46,418 & Desidrogenase / redutase \\
\hline ATEG_02590 & 63,658 & Proteína secretada rica em cisteína & ATEG_08444 & 40,192 & Monooxigenase (FMO) \\
\hline ATEG_03468 & 60,082 & Citocromo P450 & ATEG_00687 & 36,726 & Proteína hipotética \\
\hline
\end{tabular}




\begin{tabular}{|c|c|c|c|c|c|}
\hline ATEG_07147 & 52,132 & Fenol mono-oxigenase & ATEG_05002 & 31,414 & Beta-glucosidase \\
\hline ATEG_03466 & 48,988 & Proteína hipotética & ATEG_07493 & 30,957 & Celobiohidrolase \\
\hline S36xG36 & \multicolumn{5}{|c|}{ S48xG48 } \\
\hline ATEG_04991 & 351,455 & Endopoligalacturonase & ATEG_02687 & 1084,777 & Proteína integral de membrana \\
\hline ATEG_07383 & 351,277 & Proteína hipotética & ATEG_08654 & 828,838 & Endo-beta-mannanase \\
\hline ATEG_02687 & 278,808 & Proteína integral de membrana & ATEG_04642 & 509,585 & Allantoate permease \\
\hline ATEG_00891 & 275,239 & Proteína hipotética & ATEG_03640 & 481,137 & Cutinase \\
\hline ATEG_05082 & 190,681 & Proteína hipotética & ATEG_07497 & 405,622 & Proteína de ligação a quitina \\
\hline ATEG_10071 & 150,916 & Alpha-L-arabinofuranosidase & ATEG_04991 & 377,383 & Endopoligalacturonase \\
\hline ATEG_04709 & 149,913 & Acetil xilana esterase & ATEG_04792 & 341,500 & Proteína hipotética \\
\hline ATEG_07190 & 131,336 & Endo-1,4-beta-xilanase & ATEG_04707 & 319,657 & $\begin{array}{l}\text { Proteína de transporte de } \\
\text { membrana (MFS) }\end{array}$ \\
\hline ATEG_05874 & 127,659 & Proteína hipotética & ATEG_07383 & 300,699 & Proteína hipotética \\
\hline ATEG_00809 & 124,783 & Endo-1,4-beta-xilanase & ATEG_00891 & 289,444 & Proteína BNR/Asp-box \\
\hline B48xB36 & \multicolumn{5}{|c|}{ G48xG36 } \\
\hline ATEG_04438 & 12,959 & Proteína predita & ATEG_00588 & 5,968 & Proteína integral de membrana \\
\hline ATEG_07373 & 4,630 & Carboxypeptidase & ATEG_01896 & 4,787 & Proteína hipotética \\
\hline ATEG_01669 & 3,404 & Proteína predita & ATEG_05895 & 4,784 & Fosfoenolpiruvato carboxicinase \\
\hline ATEG_03801 & 3,181 & Proteína hipotética & ATEG_02028 & 4,746 & Proteína hipotética \\
\hline ATEG_09491 & 2,709 & Proteína hipotética & ATEG_00046 & 3,953 & Gama-liase de cistationina \\
\hline ATEG_07720 & 2,575 & Triptofano sintase & ATEG_02890 & 3,769 & Transporte monocarboxilato \\
\hline ATEG_02688 & 2,559 & Proteína predita & ATEG_06331 & 3,241 & Alfa-cetoglutarato-dioxigenase \\
\hline ATEG_04396 & 2,489 & Proteína hipotética & ATEG_03891 & 3,224 & Fosfatidil sintase \\
\hline ATEG_04792 & 2,424 & Proteína hipotética & ATEG_06047 & 0,200 & Transportador de açúcar (MFS) \\
\hline ATEG_10088 & 2,394 & Proteína hipotética & ATEG_02268 & 0,076 & Acil CoA desidrogenase \\
\hline \multicolumn{6}{|l|}{ S48xS36 } \\
\hline ATEG_00759 & 18,978 & Indoleamina 2,3-dioxigenase & & & \\
\hline ATEG_02799 & 13,251 & Proteína hipotética & & & \\
\hline ATEG_06626 & 13,204 & Carboxilato desidrogenase & & & \\
\hline
\end{tabular}




\begin{tabular}{lcc} 
ATEG_02506 & 6,689 & Proteína hipotética \\
ATEG_06627 & 5,206 & Prolina oxidase \\
ATEG_10009 & 4,742 & Aldeído desidrogenase \\
ATEG_04372 & 4,297 & Domínio beta lactamase \\
ATEG_07834 & 4,184 & Proteína hipotética \\
ATEG_03900 & 4,137 & Protease alcalina \\
ATEG_03190 & 3,949 & Transportador de açúcar (MFS) \\
\hline
\end{tabular}




\subsubsection{Análises dos genes que expressam enzimas envolvidas na degradação da parede celular vegetal do $A$. terreus BLU24 quando cultivado em resíduos agroindustriais}

A montagem e degradação de polímeros de carboidratos e glicoconjugados são realizados por um painel diverso de enzimas denominadas Carboidratos-ativos, ou " CAZymes". O sistema de classificação CAZymes, com base na similaridade de aminoácidos e mecanismos enzimáticos, foi integrado e atualizado na base de dados cazy (www.cazy.org) desde 1998. Atualmente o Cazy incorpora mais de 300 famílias subdivididas nas seguintes classes: glicosil hidrolases (GH), glicosil transferases (GT), polissacarídeos liases (PL), carboidratos esterases (CE), e módulos de ligação a carboidratos (CBM) (Levasseur et al., 2013).

As análises de RNA-seq do isolado A. terreus BLU24 cultivado em bagaço de cana de açúcar identificaram um total de 102 genes CAZy, já em casca do grão da soja o total de genes CAZy foi 159 (padj <0.01).

No tratamento contendo bagaço de cana de açúcar (figura 22) foi encontrado um total de 29 genes que codificam proteínas da família glicosil hidrolase e que estão possivelmente relacionados com a despolimerização da celulose e 23 genes que codificam proteínas da família glicosil hidrolase e que estão provavelmente relacionados com a despolimerização da hemicelulose. Já no tratamento contendo casca do grão da soja (figura 23) foi encontrado um total de 35 genes que codificam proteínas da família glicosil hidrolase e que estão provavelmente relacionados com a despolimerização da celulose e 28 genes que codificam proteínas da família glicosil hidrolase e que estão possivelmente relacionados com a despolimerização da hemicelulose. Estes resultados mostram o potencial para a descoberta de genes envolvidos na produção de celulases e hemicelulases em A. terreus durante o seu crescimento sob diferentes fontes de carbono. As diferentes categorias de genes CAZy expressos durante a exposição ao bagaço de cana de açúcar e a casca da soja mostra a complexidade de carboidratos presentes nos substratos.

Além disso, foram encontrados 3 genes que codificam proteínas da família CE e 2 genes que codificam proteínas da família CBM no tratamento com bagaço de cana de 
açúcar e 1 gene da família CE, 2 genes da família PL, 2 genes da família CBM e 2 genes da família GT no tratamento com casca do grão da soja.

Tanto no tratamento contendo bagaço de cana de açúcar quanto no tratamento contendo casca do grão da soja as famílias mais abundantes foram a GH3 e GH43. Os dados revelam que no tratamento com bagaço de cana de açúcar foram encontrados 6 genes que codificam proteínas da família GH5, 7 genes da família GH43 e 8 genes da família GH3. Já no tratamento com casca do grão da soja foram relatados 7 genes que codificam proteínas da família GH5, 6 genes da família GH10, 11 genes da família GH3 e 12 genes da família GH43.

A família GH3 agrupa $\beta$-D- glucosidases de ação exo, $\alpha$-L-arabinofuranosidase, $\beta$ D-xilopiranosidases e N-acetil- $\beta$-D-glucosaminidases. São amplamente distribuídas em bactérias, fungos e plantas, as enzimas GH3 realizam uma série de funções, incluindo a degradação da biomassa celulósica, remodelação da parede celular bacteriana, metabolismo energético e na defesa do patógeno (http://www.cazy.org/GH3.html).

As principais atividades da família GH43 são $\alpha$-L- arabinofuranosidases, endo- $\alpha$-Larabinanases e $\beta$-D- xilosidases. Uma enzima com $\alpha$-exo-1,3-galactanase também tem sido descrita. Um número significativo de enzimas nesta família visa tanto a atividade de $\alpha$-Larabinofuranosidase quanto $\beta$-D-xilosidase utilizando aril-glicósidicos como substratos (http://www.cazy.org/GH43.html).

Outro dado relevante do presente trabalho foi à abundância de genes que codificam proteínas da família AA9, conhecidas por proteínas auxiliares e que foram recentemente reanotadas na base de dados do CAZy, sendo esta uma extensa classe de módulos não estritamente restritos a um simples mecanismo catalítico ou específicos substratos, que são caracterizadas e atualizadas no banco de dados pelas suas relevâncias bioquímicas e similaridades com modelos considerados âncoras funcionais (Levasseur et al., 2013). Dentre a nova AA classe, as LPMos anteriormente classificadas como GH61 (Harris et al., 2010) e as celobiose desidrogenases ( $\mathrm{CDH})$ vem sendo as enzimas mais amplamente estudadas. Por um longo período de pesquisas as LPMos família AA9 foram reportadas por possuírem baixa atividade de endoglucanase, entretanto estudos reportaram que alguns membros da glicosídeo hidrolase família 61 podiam dinamizar a atividade de celulase resultando no aumento da conversão da biomassa vegetal (Merino e Cherry, 2007), 
aumentando o interesse da massa pesquisadora na resolução e entendimento dessa família. Foram encontrados 6 genes que codificam proteínas da família AA9 no tratamento com casca do grão da soja como fonte de carbono e 5 genes no tratamento com bagaço de cana de açúcar.

Estudos recentes têm demonstrado que a quebra de polissacarídeos cristalinos pode ser impulsionada pela ação de monoxigenases de polissacarídeos líticos (LPMO’s). Esses LPMO's são classificados como subgrupos, AA9, AA10, AA11 e AA13 no banco de dados CAZy. As LPMO's exibem clivagem oxidativa entre glicosil $\beta$ (1-4) em unidades de quitina, celulose, hemicelulose sob a formação de gluco-oligossacarídeos oxidados. As LPMO's constituem uma nova classe de enzimas oxidativas e espera-se que elas desempenham um papel crucial na degradação da biomassa lignocelulósica (Agger et al., 2014).

Evidências da existência de um mecanismo entre as atividades de CDH e GH61 têm sido discutidos por Langston (2011) que avaliou a combinação das enzimas GH61 e CDH de Thielavia terrestris observando o aumento da conversão de celulose pelo coquetel contendo celulases hidrolíticas, além da liberação de diferentes oligossacarídeos quando a mistura GH61 e CDH estava presente, demonstrando evidências da presença do sistema celulolítico oxidativo em paralelo as celulases hidrolíticas (Langston et al., 2011).

No tratamento com casca do grão da soja também foi encontrado genes que codificam proteínas relacionadas com a degradação da pectina, como por exemplo, um gene da família GH28, um gene da família GH 78 e um gene da família GH88. 


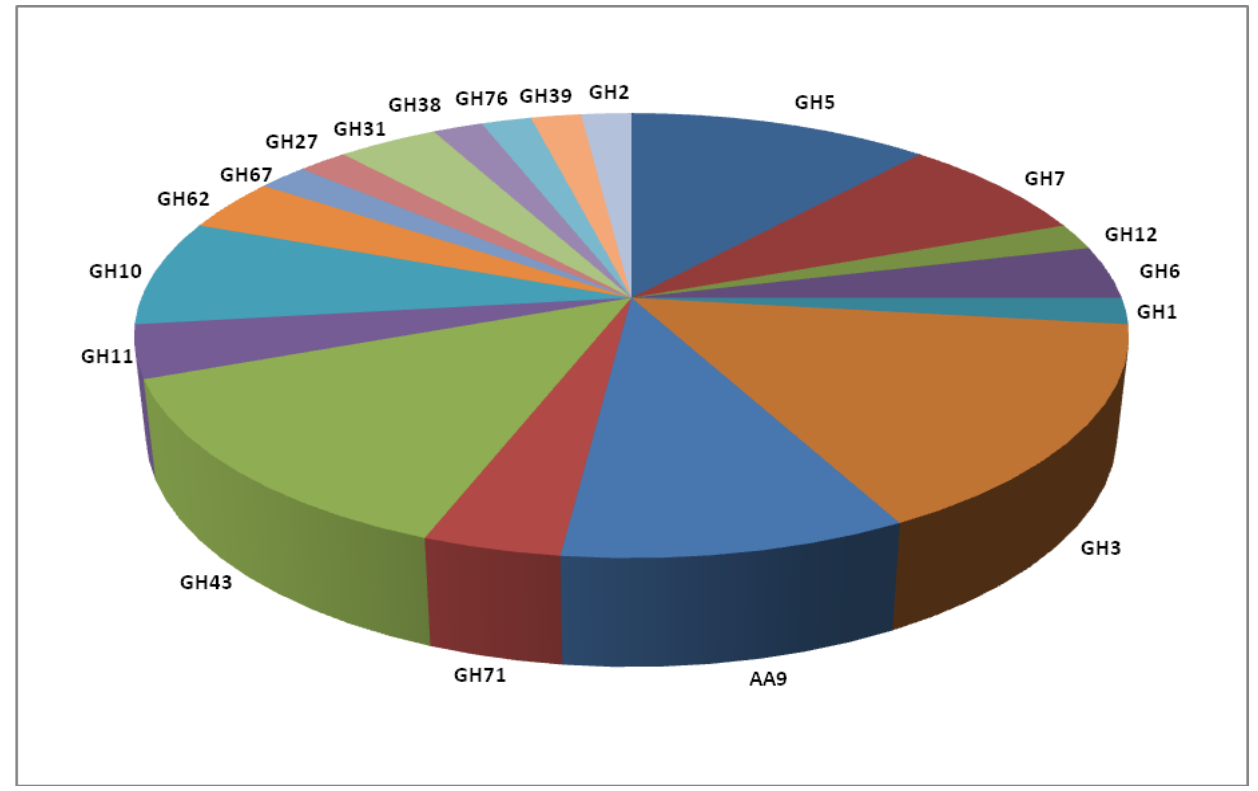

Figura 22: Genes classificados na análise do transcritoma de A. terreus cultivado em bagaço de cana de açúcar nos tempos de 36 e 48 horas, de acordo com a abundância de enzimas classificadas como CAZy. padj $<0,01$

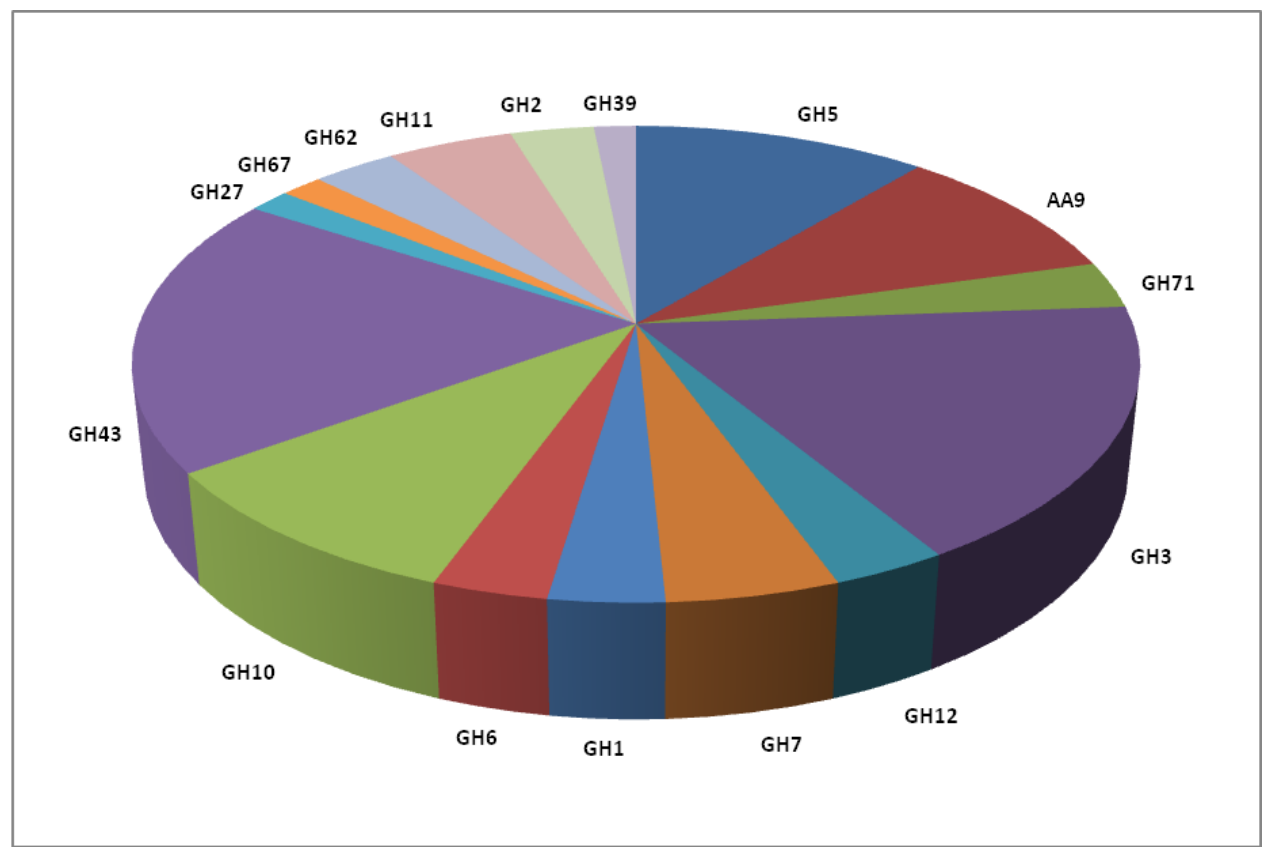

Figura 23: Genes classificados na análise do transcritoma de A. terreus cultivado em casca do grão da soja, nos tempos de 36 e 48 horas de acordo com a abundância de enzimas classificadas como CAZy. padj $<0,01$ 
O diagrama de venn (figura 24) evidencia a distribuição dos genes CAZy nos quatro tratamentos contrastantes. Pode-se inferir que 35 genes ocorrem nos quatro tratamentos, ou seja, uma quantidade maior de genes relacionados com a degradação da parede celular vegetal ocorre tanto na casca do grão da soja quanto no bagaço de cana de açúcar nos dois tempos estudados. Entretanto, temos uma quantidade menor de genes que ocorre de forma exclusiva em cada tratamento. Os genes exclusivos de cada tratamento foi listado na tabela 6.

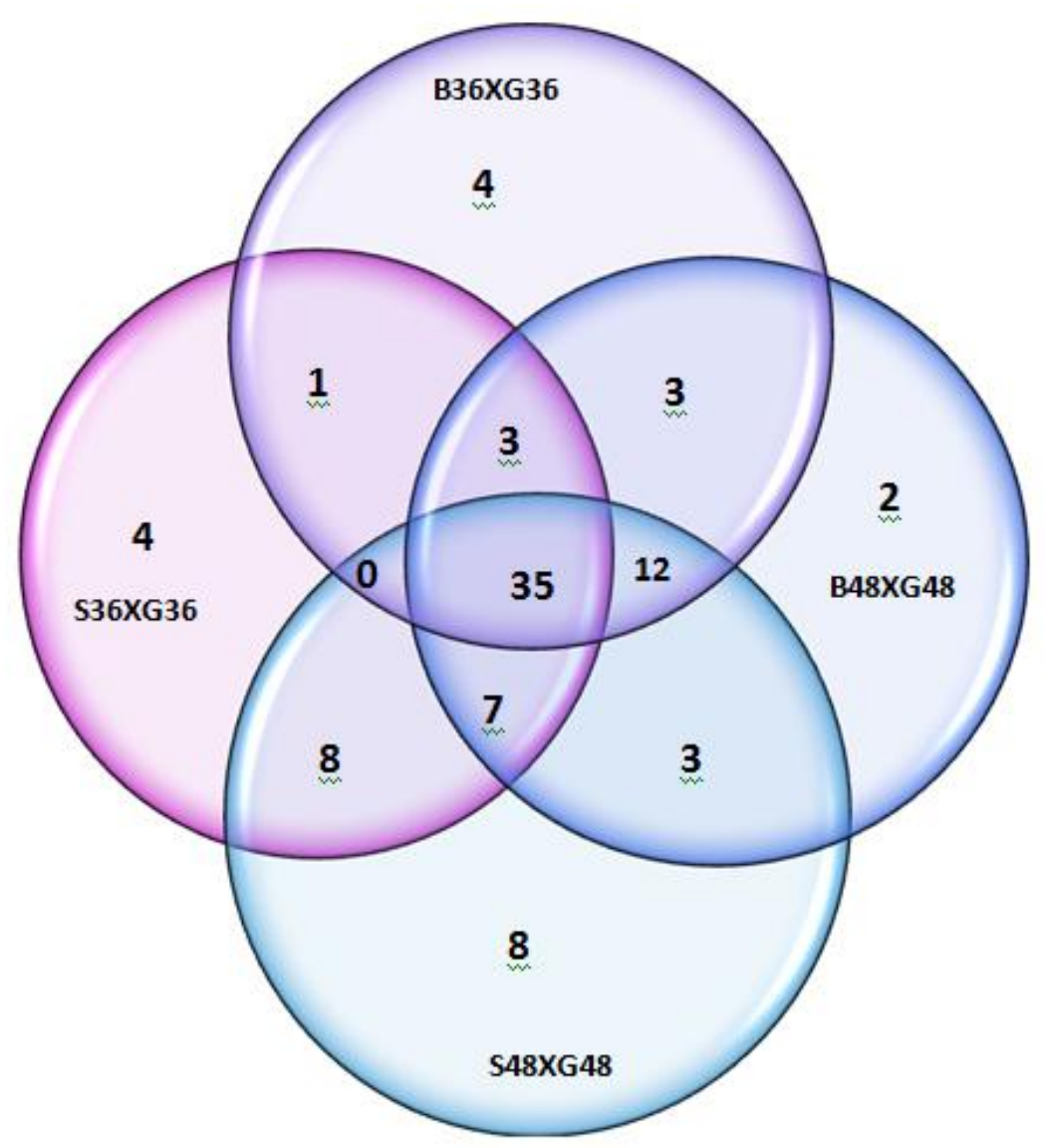

Figura 24: Diagrama de Venn mostrando a distribuição dos genes CAZY nos tratamentos bagaço de cana de açúcar e casca do grão da soja comparado com a glicose nos tempos de 36 e 48 horas. Log2foldchange> 2, padj <0,01. (B36xG36 - expressão de genes de bagaço de cana de açúcar contra glicose no tempo de 36 horas; B48xG48 - expressão de genes de bagaço de cana contra glicose no tempo de 48 horas; S36xG36 - expressão de genes da casca do grão da soja contra glicose no tempo 36 horas; S48xG48 - expressão dos genes da casca do grão da soja contra glicose no tempo 48 horas). 
Tabela 6: A tabela mostra os genesrelacionados com a degradação da parede celular de plantas que ocorreram exclusivamente em cada tratamento (casca do grão da soja 36 e 48 horas e bagaço de cana de açúcar 36 e 48 horas), com o identificador do gene, $\log 2$ foldchange e anotação de cada gene codificado, padj $<0,01$.

\begin{tabular}{|c|c|c|c|}
\hline Tratamento & Gene & log2foldchange & Enzima \\
\hline \multirow[t]{4}{*}{ B36xG36 } & ATEG_02996 & 4.908768955 & Celobiose desidrogenase \\
\hline & ATEG_09048 & 2.254628915 & Endo mananase \\
\hline & ATEG_03727 & 2.907929825 & Exoglucanase \\
\hline & ATEG_07929 & 2.637363699 & $\alpha$-galactosidase \\
\hline \multirow[t]{2}{*}{ B48xG48 } & ATEG_10194 & 5.054154127 & Endoglucanase \\
\hline & ATEG_04390 & 4.00862113 & Endoglucanase \\
\hline \multirow[t]{4}{*}{ S36xG36 } & ATEG_08279 & 2.646911608 & $\alpha$-amilase \\
\hline & ATEG_08278 & 3.33516254 & $\alpha$-glucosidase \\
\hline & ATEG_04963 & 5.736092215 & Glicosil hidrolase \\
\hline & ATEG_00990 & 2.322618851 & Glicosil transferase \\
\hline \multirow[t]{8}{*}{ S48xG48 } & ATEG_02966 & 5.566235598 & $\alpha$-glucosidase \\
\hline & ATEG_02922 & 4.755979524 & $\alpha$-L-ramnosidase \\
\hline & ATEG_02892 & 2.414902242 & Glicosil hidrolase \\
\hline & ATEG_09745 & 2.508351854 & Glicosil hidrolase GH2 \\
\hline & ATEG_10292 & 5.978820105 & Celulase \\
\hline & ATEG_05177 & 2.856606424 & $\alpha$-glucosidase \\
\hline & ATEG_07152 & 2.028860862 & Galacturano 1,4- $\alpha$-galacturonidase \\
\hline & ATEG_04316 & 5.561404496 & Proteína hipotética \\
\hline
\end{tabular}

Os genes que codificam proteínas relacionadas com a degradação da biomassa são expressos nas duas fontes de carbono estudadas, porém alguns desses genes com expressão diferencial ocorreram apenas no bagaço de cana de açúcar ou apenas na casca do grão da soja nos tempos de 36 e 48 horas. O tratamento S48xG48 foi o que obteve um maior número de genes exclusivos, dentre eles, temos duas $\alpha$-glucosidase, enzima que decompõe 
amido em glicose e dissacarídeos. No tratamento S36xG36, além de glicosil hidrolases, observa-se também uma $\alpha$-amilase e uma $\alpha$-glucosidase. No tratamento B36xG36, temos uma celobiose desidrogenase que é uma enzima auxiliar classificada dentro da família AA3, uma endo mananase, uma exoglucanase e uma $\alpha$-galactosidade. Já no tratamento B48xG48 observam-se apenas dois genes exclusivos do tratamento, ambos codificam para endoglucanases. Esta tabela evidencia que nas fontes de carbono (BCA ou CGS), existem genes diferencialmente expressos que ocorrem de forma exclusiva em tempos diferentes. $\grave{E}$ importante relatar a importância de conhecer genes que ocorrem de forma exclusiva em uma determinada fonte de carbono, pois conhecer como esses genes são regulados é uma forma de explicar como ocorre o processo de desconstrução da biomassa vegetal.

Coradetti e colaboradores (2012) utilizaram recursos genômicos de $N$. crassa e identificaram dois fatores de transcrição conservados que são importantes reguladores de genes que codificam enzimas necessárias para a desconstrução da celulose. Os dados do estudo sugeriram que espécies fúngicas desenvolveram mecanismos independentes para a expressão de genes que codificam para celulases e hemicelulases em resposta a indutores diferentes a partir de celulose e hemicelulose.

Uma combinação no processo de engenharia e mutagênese aleatória em espécie de fungos melhoraram muito a produção de enzimas hidrolíticas a partir de estirpes industriais. No entanto, uma engenharia racional das redes reguladoras provavelmente será necessária para aumentar a produtividade e a especificidade da secreção de enzimas (Coradetti et al., 2012). Com isso, os estudos de transcritômica em fungos cultivados em diferentes fontes de carbono são essenciais para ajudar no conhecimento das redes reguladoras dos processos de degradação da biomassa vegetal. 


\section{CONCLUSÃO}

Foi utilizada neste estudo uma estratégia em nível de sistemas, combinando análise do perfil enzimático juntamente com a análise do transcritoma do A. terreus para aumentar a compreensão sobre a rede de enzimas e moléculas importantes na degradação da parede celular vegetal.

Atualmente enzimas de fungos filamentosos vêm sendo utilizadas em diferentes áreas da indústria e biotecnologia, com diferentes consórcios enzimáticos. Porém, temos principalmente, enzimas oriundas do T. reesei, A. nidulans, N.crassa, A. niger que são fungos bem conhecidos. A completa degradação da biomassa requer um arsenal enzimático que provém de muitos fungos filamentosos estudados. O cenário atual ainda conta com um gargalo na produção das enzimas para fins industriais, visto que a recalcitrância da parede celular vegetal contribui para uma redução da eficiência e produtividade. O preço das enzimas que estão no mercado também não é favorável para uma produção em larga escala, como a produção de biocombustível, papel e etc, com isso, a pesquisa nesta área é essencial para melhorar os processos até o produto final.

Diferentes indústrias necessitam de uma variedade de enzimas com finalidades diferentes, portanto, enzimas microbianas têm sido estudadas por suas características especiais aplicáveis em vários processos biológicos. As técnicas de biologia molecular têm permitido adaptar um microrganismo específico, para aumentar os rendimentos de produção enzimática com qualidades diferenciais desejadas, tais como, a estabilidade térmica, tolerância a temperatura elevada, tolerância a meios ácidos ou alcalinos, etc. Portanto, conhecer a biologia de um microrganismo específico, é essencial para alcançar o sucesso na indústria biotecnológica.

Em termos de potencial para descobrir novas enzimas úteis para a bioconversão de matérias-primas celulósicas são necessárias novas espécies de fungos candidatos para uma investigação mais profunda. As análises de transcritoma são importantes neste aspecto, pois visa, aprofundar o conhecimento da expressão de genes e moléculas indutoras que auxiliam o processo de desconstrução da biomassa vegetal. Aqui, o estudo do transcritoma global do fungo A. terreus (BLU24) cultivado em dois resíduos agroindustriais (bagaço de cana de 
açúcar e casca do grão da soja) identificou uma grande quantidade de genes que codificam enzimas utilizadas na degradação da parede celular vegetal e também fatores de transcrição que são importantes neste processo. A. terreus também investigado em outros estudos é um fungo promissor na produção de enzimas celulolíticas e hemicelulolíticas, e com um aspecto importante, produzir enzimas termotolerantes, um dado importante por exemplo, para a produção de biocombustível.

O sequenciamento via Illumina Hiseq 2500 foi uma metodologia apropriada para análise acurada da expressão gênica diferencial e permitiu uma alta cobertura (2,7 GB) do genoma do A. terreus. Quando cultivado em bagaço de cana de açúcar e casca do grão da soja o fungo A. terreus apresentou uma expressão diferencial de genes relacionados à degradação da parede celular vegetal e muitos desses genes poderão ser utlizados em trabalhos futuros. 


\section{PERSPECTIVAS}

Visando o alcance dos objetivos do presente estudo novas análises do transcritoma de A. terreus BLU24 serão realizadas com o objetivo de conhecer a rede metabólica dos principais genes celulolíticos e hemicelulolíticos. Alguns genes que foram superexpressos e subexpressos em bagaço de cana de açúcar e casca do grão da soja serão utilizados para o desenho de iniciadores específicos e validação por PCR em tempo real. Por último, será

escrito um artigo científico com os principais resultados do presente estudo. Após a identificação de genes promissores durante o cultivo de A. terreus em bagaço de cana de açúcar e casca do grão da soja poderá ser realizado construtos de levedura (Saccharomyces cerevisiae) com intuito de otimizar o processo de fermentação para produção de biocombustível. Realizar o cultivo do fungo A. terreus em altas temperaturas e analisar a produção enzimática comparando com os dados do presente estudo é outra ferramenta importante para alcançar um sucesso na eficiência e produtividade de enzimas fúngicas. Visto que no futuro poderá ser realizado o melhoramento genético do isolado afim de conseguir aumentar a expressão de genes importantes no desenvolvimento do fungo e que já foi identificado no presente trabalho. Visto que muitos processos industriais utilizam o acesso fácil de resíduos de açúcares contidos dentro da celulose ou de outros polissacarídeos das plantas, o conhecimento funcional de genes e vias regulatórias de $A$. terreus cultivado em resíduos agroindustriais é de extrema importância para o avanço da indústria e biotecnologia. Outro fato importante deste estudo é que compreender melhor o processo de degradação do polissacarídeo vegetal vai ajudar a projetar uma mistura de enzimas que pode degradar de forma mais eficiente uma ampla variedade de substratos. 


\section{REFERÊNCIAS BIBLIOGRÁFICAS}

Agger JW, Isaksen T, Varnai A, Vidal-Melgosa S, Willats WG, Ludwig R et al: Discovery of LPMO activity on hemicelluloses shows the importance of oxidative processes in plant cell wall degradation. Proc Natl Acad Sci USA 2014, 111(17): 6287-6292.

Antoniolli ZI, Schachtman D, Ophelkeller D, Smith SE: Variation in ribosomal internal transcribed spacer sequences in Glomus mosseae and Gigaspora margarita spores from a permanent pasture. Mycological Research, Amsterdam 2000, v.104, 1:708-715.

Aro N, Saloheimo A, Ilmén M, Penttilä M: ACEII, A novel transcriptional activator involved in regulation of cellulase and xylanase genes of Trichoderma reesei. J Biol Chem 2001, 276:24309-24314.

Aro N, Pakula T, Penttila M: Transcriptional regulation of plant cell wall degradation by filamentous fungi. FEMS Microbiology Reviews 2005, 29:719-739.

Badhan A, Chadha BS, Kaur J, Saini HS, Bhat MK: Role of transglycosylation products in the expression of multiple xylanases in Myceliophthora sp. Current Microbiology 2007, 54:405-409.

Balagee SA: Aspergillus terreus complex. Medical Mycology 2009, 47:S42-S46.

Basso TP, Gallo CR, Basso LC: Cellulolytic activitity of isolated fungi from sugarcane bagasse and decayed wood. Pesq Agrop Brasileira 2010, 45 (11):1282-9.

Baudel HM. Pré-tratamento e hidrólise. In workshop tecnológico sobre: hidrólise para produção de etanol. Campina, Unicamp 2006.

Bey M, Zhou S, Poidevin L, Henrissat B, Coutinho PM, Berrin JG, Sigoillot JC: Cello-oligosaccharide oxidation reveals differences between two lytic polysaccharide monooxygenases (family GH61) from Podospora anserina. Appl Environ Microbiol 2013, 79: 488-496.

Beg QK, Bhushan B, Kapoo M, Hoondal GS: Enhanced production of a thermostable xylanase from Streptomyces sp. QG-11-3 and its application in biobleaching of eucalyptus kraft pulp. Enzyme Microbiol. Technol 2000, 27: 459-466.

Beg QK, Kapoor M, Mahajan L, Hoondal GS: Microbial xylanase and their industrial application: a review. Appl. Microbiol. Biotechnol 2001, 56: 326-338.

Bellemain E, Carlsen T, Brochmann C, Coissac E, Taberlet Kauserud H. ITS as na environmental DNA barcode for fungi: na in silico approach reveals potential PCR biases. BMC Microbiology 2010, 10:189 Bentley, D.R: Whole-genome re-sequencing. Curr. Opin. Genet. Dev 2006, 16: 545-552.

Bonnarme P, Gillet B, Sepulchre AM, Role C, Beloeil JC, \& Ducrocq C: Itaconate biosynthesis in Aspergillus terreus. Journal of Bacteriology 1995, 177: 3573-3578.

Brandelli A: Bacterial keratinases: useful enzymes for bioprocessing agroindustrial wastes and beyond. Food Bioprocess Technol 2008, 1: 105-116.

Brasileiro ACM, Carneiro VTC (eds): Manual de Transformação Genética de Plantas. Brasília, EmbrapaSPI/ Embrapa-Cenargen 1998. 
Camassola M, Dillon A J P: Production of cellulases and hemicellulases by Penicillium echinulatum grown on pretreated sugar cane bagasse and wheat bran in solid state fermentation. J Appl Microbiol 2007, 103: 2196-204.

Cantarel BL, Coutinho PM, Rancurel C, Bernard T, Lombard V, Henrissat B: The carbohydrate-active enzymes database (CAZy); http://www.cazy.org/. Accessed 25 Oct 2011.

Castro AM, Jr NP: Produção, propriedades e aplicação de celulases na hidrólise de resíduos agroindustriais. Quim. Nova 2010, 33: 181-188.

Castro LS, Antoniêto ACC, Pedersoli WR, Silva-Rocha R, Persinoti GF, Silva RN: Expression pattern of cellulolytic and xylanolytic genes regulated by transcriptional factors XYR1 and CRE1 are affected by carbon source in Trichoderma reesei. Gene Expression Patterns 2014, 14: 88-95.

Chapla D, Divecha J, Madamwar D, Shah A: Utilization of agro-industrial waste for xylanase production by Aspergillus foetidus MTCC 4898 under solid state fermentation and its application in saccharification. Biochemical Engineering Journal 2010, 49: 361-369.

Chen, CA., et al: Secondary structure and phylogenetic utility of the Ribossomal Internal Transcribed Spacer 2 (ITS2) in Scleractinian corals. Zoological Studies 2004, 43: 759-771.

Christov LP, Szakacs G, Balakrishnan H: Production, partial characterization and use of fungal cellulase free xylanases in pulp beleaching process. Biochemistry 1999, 34: 511-517.

Collins T, Gerday C, Feller G: Xylanases, xylanase families and extremophilic xylanases. Microbiology Reviews 2005, 29: 3-23.

http://www.conab.gov.br/OlalaCMS/uploads/arquivos/15_04_13_09_39_02_boletim_cana_portugues_-

_10_lev_-_15-16.pdf

Conesa A, Gotz S, Garcia Gomez JM, Terol J, Talon M, Robles M. Blast2GO: A universal tool for annotation, visualization and analysis in functional genomics research. Bioinformatics 2005, 21: 3674 -3676 .

Coradetti ST, Craig JP, Xiong Y, Shock T, Tian C, Glass NL: Conserved and essential transcription factors for cellulase gene expression in ascomycete fungi. PNAS Early Edition 2012.

Coutinho PM, Andersen MR, Kolenova K, vanKuyk PA, Benoit I, Gruben BS, Trejo-Aguilar B, Visser H, van Solingen P, Pakula T, Seiboth B, Battaglia E, Aguilar-Osorio G, de Jong JF, Ohm RA, Aguilar M, Henrissat B, Nielsen J, Stalbrand H, de Vries RP: Post-genomic insights into the plant polysaccharide degradation potential of Aspergillus nidulans and comparison to Aspergillus niger and Aspergillus oryzae. Fungal Genet Biol 2009, 46 (Suppl 1): S161-S169.

De Diego, Manjo'n A, Jose' L.I: Biocompatibility of ionic liquids with enzymes for biofuel production. Fang Z, Smith RJ, Jr, Qi X. (Eds.): In: Production of Biofuels and Chemicals with Ionic Liquids vol. 1. Springer, New York 2014, pp. 284- 290.

Delabona PD, Pirota RDPB, Codima CA, Tremacoldi CR, et al.: Using Amazon forest fungi and agricultural residues as a strategy to produce cellulolytic enzymes. Biomass Bioenergy 2012, 37, 43-50. 
Delmas S, Pullan ST, Gaddipati S, Kokolski M, Malla S, Blythe MJ, Ibbett R, Campbell M, Liddell S. \& Aboobaker A: Uncovering the genome-wide transcriptional responses of the filamentous fungus Aspergillus niger to lignocellulose using RNA sequencing. PLoS genetics 2012, 8:e1002875.

De Lucca AJ: Harmful fungi in both agriculture and medicine. Rev Iberoam Micol 2007, 24: 3-13.

De Souza AP, Grandis A, Leite DCC, Buckeridge MS: Sugarcane as a Bioenergy Source: History, Performance, and Perspectives for Second-Generation Bioethanol. Bioenerg. Res 2014, 7: 24-35.

Dhawan S, Kaur J: Microbial mannanases: an overview of production and applications. Crit RevBiotechnol 2007, 27: 197-216.

Doi RH, Tamaru Y: The Clostridium cellulovorans cellulosome: An enzyme complex with plant cell wall degrading activity. Chemical Records 2001, 1: 24-32.

Embrapa. Tecnologias de produção de soja Região Central do Brasil. Londrina: Embrapa Soja 2005. 237 p.

Emtiazi G, Naghavi N, Bordbar A: Biodegradation of lignocellulosic waste by Aspergillus terreus. Biodegradation 2001, 12: 259-263.

Ferreira VF, Rocha DR: Potencialidades e Oportunidades na Química da Sacarose e Outros Açúcares. Quím Nova 2009, 3:623-638.

Filho EXF, Puls J, Coughlan MP. Physicochemical and catalytic properties of a low-molecular-weight endo-1,4-b-D-xylanase from Myrothecium verrucaria. Enzyme and Microbial Technology 1993a , 15: 535540.

Focher B, Marzetti A, Crescenzi V: Steam explosion techniques: fundamentals and industrial applications. Amsterdam: Gordon and Breach Reading 1988, 413.

Foreman PK, Brown D, Dankmeyer L, Dean R, Diener S, Dunn-Coleman NS, Goedegebuur F, Houfek TD, England GJ, Kelley AS: Transcriptional regulation of biomass-degrading enzymes in the filamentous fungus Trichoderma reesei. Journal of Biological Chemistry 2003, 278: 31988-31997.

Gao J, Weng H, Xi Y, Zhu D, Han S: Purification and characterization of a novel endo-b-1,4-glucanase from the thermoacidophilic Aspergillus terreus. Biotechnol Lett 2008, 30: 323-327.

García-Kirchner O: PhD thesis, Facultad de Química, U.N.A.M. 1983, Mexico.

Goldemberg J: The role of biomass in the world's energy system. Springer New York 2010, 3-14.

Gupta R, Ramnani P: Microbial keratinases and their prospective applications: an overview. Appl Microbiol Biotechnol 2006, 70:21-33.

Hakkinen M, Arvas M, Oja M, Aro N, Penttila M, Saloheimo M, Pakula TM: Re-annotation of the CAZy genes of Trichoderma reesei and transcription in the presence of lignocellulosic substrates. Microb Cell Fact 2012, 11: 134

Han MJ, Kin NJ, Lee SY, Chang HN: Extracellular proteome of Aspergillus terreus grown on different carbon sources. Curr Genet 2010, 56: 369-382.

Harris PVD, Welner KC, McFarland EReJC, Navarro PK, Brown R, Salbo H, Ding E, Vlasenko S, Merino F, Xu J, Cherry S, Larsen L, Leggio L: "Stimulation of lignocellulosic biomass hydrolysis by proteins of 
glycoside hydrolase family 61: structure and function of a large, enigmatic family." Biochemistry 2010, 49 (15): 3305-16. doi: 10.1021/bi100009p.

Hayes DJ: An examination of biorefining processes, catalysts and challenges. Catal Today 2009, 145:138151.

Hillis DM; Dixon MT: Ribosomal DNA: molecular evolution and phylogenetic inference. Quartely Review of Biology 1991, Ithaca, v.66, 4: 411- 453.

Himmel M, Ding S, Johnson D, Adney W, Nimlos M, et al: Biomass recalcitrance: engineering plants and enzymes for biofuels production. Science 2007, 315: 804-7.

Horta MAC, et al: Transcriptome profile of Trichoderma harzianum IOC-3844 induced by sugarcane bagasse. PLoS ONE 2014, 9(2):1-17.

Hrmova’ M, Biely P, Vrs`anska' M: Cellulose- and xylandegrading enzymes of Aspergillus terreus and Aspergillus niger. Enzym Microb Technol 1989, 11:610-616.

Jeihanipour A, Karimi K, Niklasson C, Taherzadeh M J: A novel process for ethanol or biogas production from cellulose in blended-fibers waste textiles. Waste Management 2010, 2504-2509.

Jeihanipour A, Taherzadeh M J: Ethanol production from cotton-based waste textiles. Bioresource Technol 2009, 100:1007-1010.

Jorgensen H, Vibe-Pedersen J, Larsen J, Felby C: Liquefactio of lignocellulose at high-solids concentrations. Biotechnol Bioeng 2007, 96(5): 862-870.

Kerem Z, Friesem, D, Hadar Y: Lignocelullose degradation during solidstate fermetation: Pleorotus ostreatus versus Phanarochaete chrisporium. Applied and Environmental Microbiology 1992, 58:11211127.

Kim JY, Hur SH, Hong JH: Purification and characterization of an alkaline cellulase from a newly isolated alkalophilic Bacillus sp.HSH-810. Biotechnol Lett 2005, 27:313-316.

Kim S, Dale BE: Global potential bioethanol production from wasted crops and crop residues. Biomass and Bioenergy 2004, 26: 361-75.

King BC, Waxman KD, Nenni NV, Walker LP, Bergstrom GC, Gibson DM: Arsenal of plant cell wall degrading enzymes reflects host preference among plant pathogenic fungi. Biotechnology for Biofuels 2011, 4 .

Kirchner OG, Aguilar MM, Villalva RP, Vargas CH: Mixed Submerged Fermentation with Two Filamentous Fungi for Cellulolytic And Xylanolytic Enzyme Production. Applied Biochemistry and Biotechnology 2002, 98-100.

Kotchoni SO, Shonukan OO: Regulatory mutations affecting the synthesis of cellulase in Bacillus pumilus. World J. Microbiol Biotechnol 2002, 18:487-491.

Kuenz A, Gallenmuller Y, Willke T, \& Vorlop KD: Microbial production of itaconic acid: developing a stable platform for high product concentrations. Applied Microbiology and Biotechnology 2012, 96:12091216. 
Langston JAT, Shaghasi E, Abbate F, Xu E, Vlasenko, Sweeney MD: "Oxidoreductive cellulose depolymerization by the enzymes cellobiose dehydrogenase and glycoside hydrolase 61." Appl Environ Microbiol 2011, 77 (19):7007-15. doi: 10.1128/AEM.05815-11.

Le Quéré A, Johansson T, Tunlid A: Genome size and complexity of the ectomycorrhizal fungus Paxillus involutus. Fungal Genet Biol 2002, 36: 234-241.

Levasseur A, Drula E, Lombard V, Coutinho PM, Henrissat B: Expansion of the enzymatic repertoire of the CAZy database to integrate auxiliary redox enzymes. Biotechnology for Biofuels 2013, 6: 41.

Lin X, Zhang J, Li Y et al: "Functional genomics of a living fossil tree, Ginkgo, based on next-generation sequencing technology”. Physiologia Plantarum 2011, vol. 143, 3: 207-218.

Lincoln T, Eduardo Z. Plant Physiology. Sinauer Associates Inc., Sunderland, MA 2002, 3rd Edition.

Lombard V, Ramulu HG, Drula E, Coutinho PM, Henrissat B: The carbohydrate-active enzymes database (CAZy) in 2013. Nucleic Acids Research 2013, D490:D495.

Lynd LR, Weimer PJ, Willem H, Zyl V, Isak S: Microbial Cellulose Utilization: Fundamentals and Biotechnology. Microbiol. Mol. Biol. Rev 2002, 66(3):506.

Maeda H, Sano M, Maruyama Y, Tanno T, Akao T, Totsuka Y, Endo M, Sakurada R, Yamagata Y, Machida $\mathrm{M}$,et al. : Transcriptional analysis of genes for energy catabolism and hydrolytic enzymes in the filamentous fungus Aspergillus oryzae using cDNA microarrays and expressed sequence tags. Appl. Microbiol. Biotechnol 2004, 65: 74-83.

Maijala P, Kango N, Szijarto N, Viikari L: Characterization of hemicellulases from thermophilic fungi. Springer Science 2012, 101: 905-917.

Margolles-Clark M, Ilme'n M, Penttil M: Expression patterns of 10 hemicellulase genes from filamentousfungus Trichoderma reesei on various carbon sources. J. Biotechnol 1997, 57:167-179.

Marques EK, Ikuta N, Lunge VR, Fonseca ASK. Diagnóstico molecular e biotecnologia: avanços na agricultura e na agroindústria. Caxias do Sul: EDUCS, 2002. p.101-129.

Marques S, Pala H, Alves L, Amaral-Collaco MT, Gama FM, Girio FM: Characterisation and application of glycanases secreted by Aspergillus terreus CCMI498 and Trichoderma viride CCMI 84 for enzymatic deinking of mixed office wastepaper. J Biotechnol 2003, 100: 209-219.

Martens-Uzunova ES, Schaap PJ: Assessment of the pectin degrading enzyme network of Aspergillus niger by functional genomics. Fungal Genet Biol 2009, 46(Suppl 1):S170-S179.

Martinez AT, Speranza M, Ruiz-Duenas FJ, Ferreira P, Camarero S, Guillen F, Martinez MJ, Gutierrez A and del Rio JC: Biodegradation of lignocellulosics: microbial, chemical, and enzymatic aspects of the fungal attack of lignin. Int Microbiol 2005, 8: 195-204.

Martinez D, Berka RM, Henrissat B, Saloheimo M, Arvas M, Baker SE, Chapman J, Chertkov O, Coutinho PM, Cullen D, Danchin EG, Grigoriev IV, Harris P, Jackson M, Kubicek CP, Han CS, Ho I, Larrondo LF, de Leon AL, Magnuson JK, Merino S, Misra M, Nelson B, Putnam N, Robbertse B, Salamov AA, Schmoll M, Terry A, Thayer N, Westerholm-Parvinen A, Schoch CL, Yao J, Barabote R, Nelson MA, Detter C, Bruce D, Kuske CR, Xie G, Richardson P, Rokhsar DS, Lucas SM, Rubin EM, Dunn- Coleman N, Ward M, Brettin 
TS: Genome sequencing and analysis of the biomass-degrading fungus Trichoderma reesei (syn. Hypocrea jecorina). Nat Biotechnol 2008, 26(5): 553-560.

Martinez-Filho J, Burnquist HL, Vian CEF: Bioenergy and the rise of sugarcane-based ethanol in Brazil. The magazine of food, farm, and resource issues. 2nd Quarter 2006, 21(2) CHOICES 91.

Medeiros RG, Silva LP, Azevedo RB, Silva-Jr FG, Ferreira-Filho EF. The use of atomic force microscopy as a tool to study the effect of a xylanase from Humicola grisea var. thermoidea in kraft pulp bleaching. Enzyme and Microbial Technology 2007, 40, 4:723-731.

Merino S, Cherry J: Progress and Challenges in Enzyme Development for Biomass Utilization. In: OLSSON, L. (Ed.). Biofuels: Springer Berlin Heidelberg 2007, 66:95-120. (Advances in Biochemical Engineering/Biotechnology). ISBN 978-3-540-73650-9.

Miller GL: Use of Dinitrosalicylic Acid Reagent for Determination of Reducing Sugar. Analytical Chemistry. 1959, 31(3): 426-28.

Moretti MMS, Bocchini-Martins DA, Da Silva R, Rodrigues A, Sette LD, Gomes E: Selection of thermophilic and thermotolerant fungi for the production of cellulases and xylanases under solid-state fermentation. Braz J Microbiol 2012, 43(3): 1062-71.

Muchow RC, Wood AW, Keating BA: Radiation interception and biomass accumulation in a sugarcane crop grown under irrigated tropical conditions. Aust J Agr Res 1994, 45: 37-49.

Nazyr A, Soni R, Saini HS, Kaur A, Chadha BS: Profiling Differential Expression of Cellulases and Metabolite Footprints in Aspergillus terreus. Appl Biochem Biotechnol 2010, 162:538-547.

Neto PRC, Rossi LFS: Produção de biocombustível alternativo ao óleo diesel através da transesterificação de óleo de soja usado em frituras. Química Nova 2000, 23(4).

Paganni NC, Eurich VRP, Franco JM: Gerenciamento de resíduos sólidos da indústria de fios em cooperativa agroindustrial. II Congresso Brasileiro de gestão ambiental 2011, Londrina, Brasil. Bauru; IBEAS.

Pauly M, Keegstra K: Cell wall carbohydrates and their modifications as a resource for biofuels. Plant $\mathrm{J}$ 2008, 54:559-68.

Pitt JI; Hocking AD. Fungi and Food Spoilage. Sydney: Academic Press, 1985.

Plácido J, Imam T, Capareda S: Evaluation of ligninolytic enzymes, ultrasonication and liquid hot water as pretreatments for bioethanol production from cotton gin trash. Bioresource Technology 2013, 139: 203-208.

Portnoy T; Margeot A; Seidl-Seiboth V; et al. : Differential regulation of the cellulase transcription factors XYR1, ACE2, and ACE1 in Trichoderma reesei strains producing high and low levels of cellulase. Eukaryotic cell 2011, v. 10, 2: 262-71.

Priolli RHG, Mendes-Junior CT, Sousa SMB, Souza NEA, Conte EPB: Diversidade genética da soja entre períodos e entre programas de melhoramento no Brasil. Pesq. Agropec. Bras, Brasília 2004, 39: 967-975. Raeder U, Broda P: Rapid preparation of DNA from filamentous fungi. Letters in Applied Microbiology 1985, Oxford, v. 1: 17-20. 
Ravalason H, Grisel S, Chevret D, Favel A, Berrin JG, Sigoillot JC, et al: Fusarium verticillioides secretome as a source of auxiliary enzymes to enhance saccharification of wheat straw. Bioresour Technol 2012, 114:589-96.

Ridley BL, O’Neill MA, Mohnen D: Pectins: structure, biosynthesis, and oligogalacturonide-related signaling. Phytochemistry 2001, 57(6):929-967.

Rodda S, Sharma S, Scherer M, Chapmam G,Rathyen P: CRTR 1 a developmentally regulated transcriptional repressor related to the $\mathbf{C P 2}$ family of transcription factors. J Biol Chem 2001, 276(5): 3324-3332.

Sarkar n, Ghosh SK, Bannerjee S, Aikat K: "Bioethanol production from agricultural wastes: An overview". Renewable Energy 2012, 37: 19-27.

Scheller HV, Ulvskov P: Hemicelluloses. Annu Rev Plant Biol 2010, 61: 263-289.

Schroeder A, Mueller O, Stocker S, Salowsky R, Leiber M, Gassmsnn M, Lightfoot S, Menzel W, Granzow M, Ragg T. The RIN: an RNA integrity number for assigning integrity values to RNA measurements. BMC Molecular Biology 2006, 7:3.

Sermanni GG, Porri A: The potentiality of solid state biotransformation of lignocellulosic materiais. Chimica oggi 1989, Março: 15 - 19.

Sharma R, Kocher GS, Bhogal RS, Oberoi HS: Cellulolytic and xylanolytic enzymes from thermophilic Aspergillus terreus RWY. J. Basic Microbiol. 2014, 54: 1-11.

Shen J, Agblevor, FA: Kinetics of enzymatic hydrolysis of steam-exploded cotton gin waste. Chem. Eng. Commun 2008, 195:1107-1121.

Shendure, J. et al: Accurate multiplex polony sequencing of an evolved bacterial genome. Science 2005, 309: 1728-1732.

Shendure J, Mitra RD, Varma C, Church GM: Advanced sequencing technologies: methods and goals. Nat. Rev. Genet 2004, 5: 335-344.

Shrestha P, Ibáñez AB, Bauer S, Glassman SI, Szaro TM, Bruns TD, Taylor JW: Fungi isolated from Miscanthus and sugarcane: biomass conversion, fungal enzymes, and hydrolysis of plant cell wall polymers. Biotechnology for Biofuels 2015, 8: 38 .

Siqueira FG: Resíduos Agroindustriais com potencial para a produção de holocelulases de origem fúngica e aplicações biotecnológicas de hidrolases. Tese (Doutorado) 2009, Universidade de Brasília, Instituto de Ciências Biológicas, Departamento de Biologia Celular.

Soni R, Nazir A, Chadha BS, Saini HS: Novel sources of fungal cellulases for eficiente deinking of composite paper waste. Bioresources 2008, 3: 234-246.

Sorensen A, Teller, PJ, Lubeck, PS, Ahring, BK: Onsite enzyme production during bioethanol production from biomass: screening for suitable fungal strains. Appl. Biochem. Biotechnol 2011, 164:1058-1070.

Stockton BC, Mitchell DJ, Grohmann K, Himmel ME: Optimum b-D glucosidase supplementation of cellulase for efficient conversion of cellulose to glucose. Biotechnol Lett 1991, 13: 57-62. 
Stricker AR, Grosstessner-Hain K, Würleitner E, Mach RL: Xyr1 (xylanase regulator 1) regulates both the hydrolytic enzyme system and D-xylose metabolism in Hypocrea jecorina. Eukaryot Cell 2006, 5: 21282137.

Sun, Y. \& Cheng, J: Hydrolysis of Lignocellulosic Materials for Ethanol Production: a Review. Bioresource Technology 2002, v. 83, n. 1: 1-11.

Szengyel, Z: Tese de Doutorado, Lund University, Suécia, 2000.

Symoens F, Bouchara JP, Heinemann S, Nolard N: Molecular typing of Aspergillus terreus isolates by random amplification of polymorphic DNA. J Hosp Infect 2000, 44: 273-280.

Tamanini C, Hauly MCO: Agro-industrial residues in biotechnological production of xylitol. Ciências Agrárias 2004, 25: 315-330.

Tian C, Beeson WT, Avarone AT, Sun J, Marletta MA, Cate JHD, Glass NL: Systems analysis of plant cell wall degradation by the model filamentous fungus Neurospora crassa. PNAS 2009, 106:52.

Urben Filho G, Souza PI de M: Manejo da cultura da soja sob cerrado: época, densidade e profundidade de semeadura. Cultura da soja nos cerrados. Piracicaba: Potafos 1993, 267-298.

US Department of Energy: Top value added chemicals from biomass, volume I: results of screening for potential candidates from sugars and synthesis gas. In: T. Werpy and G. Petersen (eds) 2004, pp. 42-44.

Van Hellemond EW, Leferink NG, Heuts DP, Fraaije MW, van Berkel WJ: Occurrence and biocatalytic potential of carbohydrate oxidases. Adv Appl Microbiol 2006, 60: 17-54.

Vares T, Kalsi M, Hatakka A: Lignin peroxidases, Manganese Peroxidases, and other ligninolytic enzymes produced by Phlebia radiata during solid-state fermentation of wheat straw. Appl. Environ Microbiol 1995, 61: 3515-3520.

Varga J, Toth B, Kocsube S, et al: Evolutionary relationships among Aspergillus terreus isolates and their relatives. Antonie Van Leeuwenhoek 2005, 88: 141-150.

Waclawovsky AJ, Sato PM, Lembke CG, Moore PH, Souza GM: Sugarcane for bioenergy production: an assessment of yield and regulation of sucrose content. Plant Biotechnol J 2010, 8(3): 263-276.

Wang X, Sun Q, McGrath SD, Mardis ER, Soloway PD, Clark AG: Transcriptome-wide identification of novel imprinted genes in neonatal mouse brain. PLoS ONE 2008, 3:e3839.

Wood V, Gwillan R, Rajandream M-A, Lyne M, Lyne R, Stewart A, Sgouros J, Peat N, Hayles J, Baker S et al.: The genome sequence of Schizosaccharomyces pombe. Nature 2002, 415:871-880.

Yang SQ, Yan Q.J, Jiang ZQ, Li LT, Tian HM, Wang YZ: High-level of xylanase production by the thermophilic Paecilomyces themophila J18 on wheat straw in solid-state fermentation. Bioresour. Technol 2006, 97:1794-1800.

Yang YS, Zhou JT, Lu H, Yuan YL, Zhao LH: Isolation and characterization of a fungus Aspergillus sp. strain F-3 capable of degrading alkali lignin. Biodegradation 2011, 22:1017-1027.

YNFX: World Fibre - Trends in Demand and Supply. 2008. 


\section{ANEXOS}

\section{Trabalhos Apresentados em Congressos}

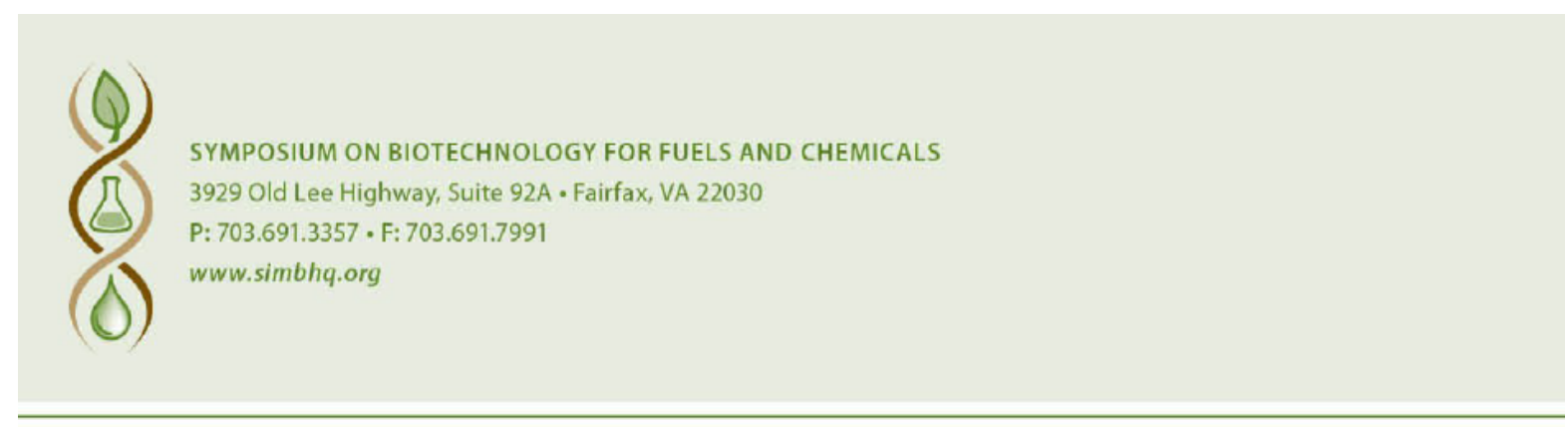

To whom it may concern:

The Society for Industrial Microbiology hereby certifies that C. L Corrêa has attended the 36th Symposium on Biotechnology for Fuels and Chemicals (April 28-May 1, 2014), and presented the following abstract:

Transcriptomic analysis of Aspergillus terreus grown on agro-industrial residues

Sincerely,

\section{Clenitrie Lowe}

Christine Lowe

Conference Coordinator
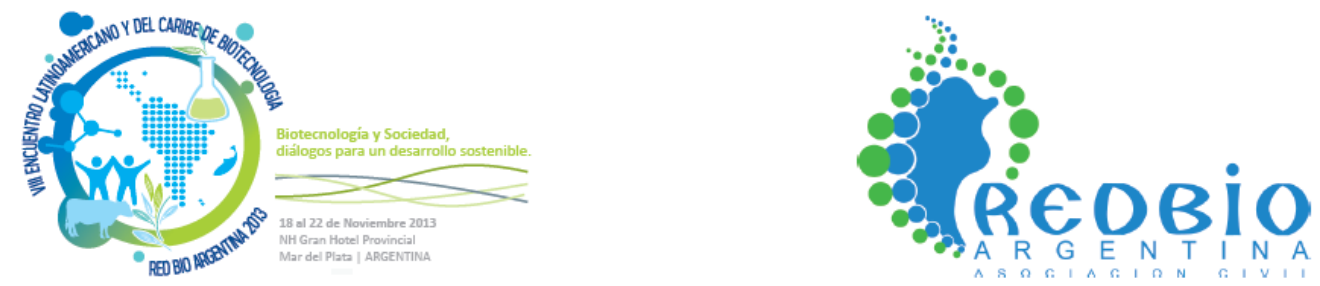

Se deja constancia que el trabajo

STUDY OF THE LIGNOCELLULOSIC POTENTIAL IN THE FUNGUS ASPERGILLUS TERREUS GROWN ON AGRO-INDUSTRIAL RESIDUES

de los autores 
Camila Louly Corrêa; Eliane Ferreira Noronha; Edivaldo Ximenes Ferreira Filho; Robert Neil Gerard Miller

ha sido presentado como poster

en el VIII Encuentro de Latinoamericano del Caribe de Biotecnología - REDBIO2013
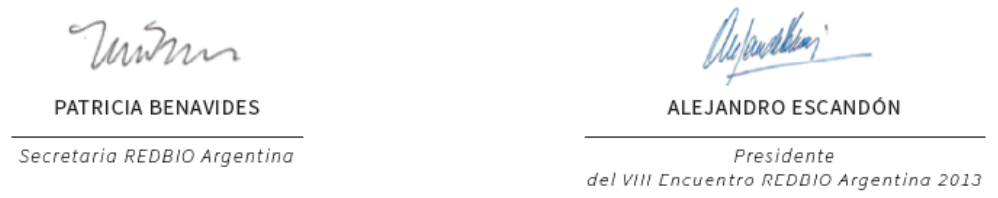

- Corrêa, C.L. ; Noronha, E.F. ; Ferreira Filho, E.X. ; Miller, R.N.G. Estudo do Potencial Lignocelulolítico do fungo Aspergillus terreus crescido em resíduos agroindustriais. ENZITEC 2012.

- Análise BLASTn da sequência das regiões ITS do rDNA (A), Calmodulina (B) e $\beta$ tubulina (C) do isolado BLU24.

(A)

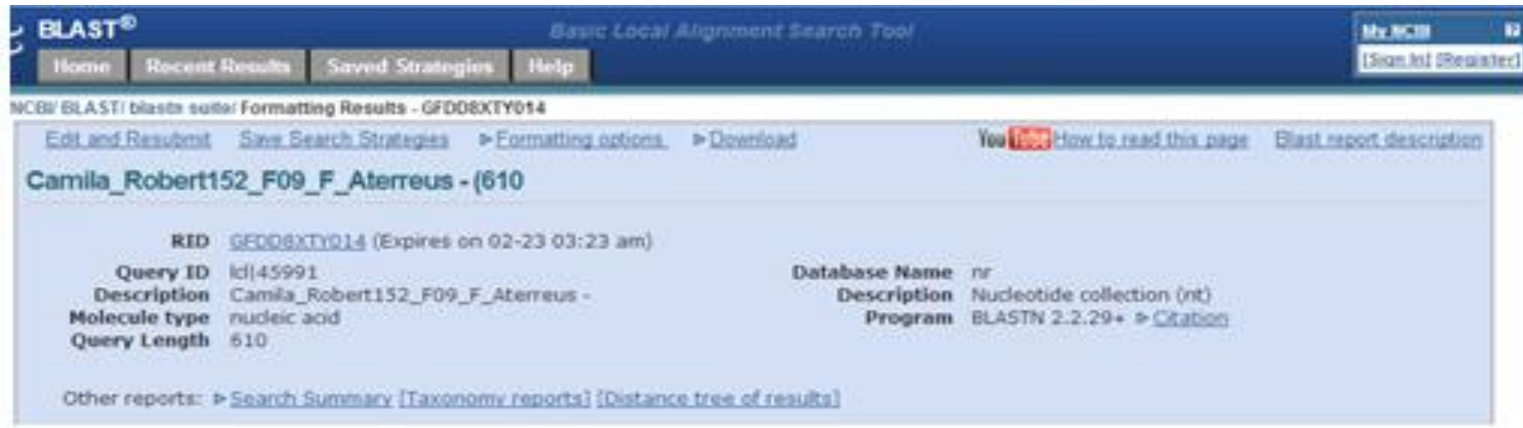

Sequences producing significant alignments:

Select: All tions Selected:0

\begin{tabular}{|c|c|c|c|c|c|c|c|}
\hline \multicolumn{8}{|c|}{ 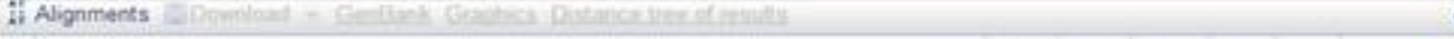 } \\
\hline & Descrigtion & $\begin{array}{l}\text { Max } \\
\text { score }\end{array}$ & $\begin{array}{l}\text { Total } \\
\text { score }\end{array}$ & $\begin{array}{l}\text { Query } \\
\text { cover }\end{array}$ & $\underset{\text { value }}{E}$ & Ident & Accessibn \\
\hline D & 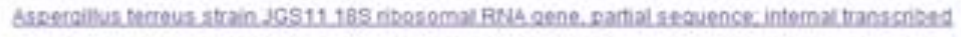 & 968 & 968 & $66 \%$ & 0.0 & $99 \%$ & sug66497.1 \\
\hline 만 & 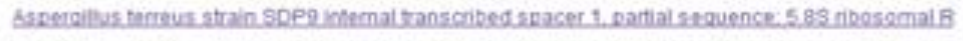 & 965 & 1154 & $89 \%$ & 00 & $99 \%$ & Kesesest.1 \\
\hline ए & 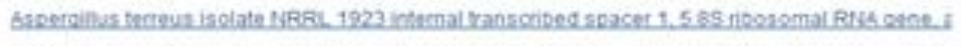 & 963 & 963 & $89 \%$ & 0.0 & $99 \%$ & EF6896001 \\
\hline E & 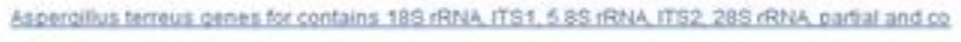 & 953 & 953 & $88 \%$ & 0.0 & $99 \%$ & 49651657.1 \\
\hline [1] & 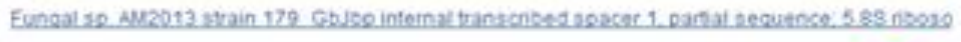 & 946 & 946 & $86 \%$ & 0.0 & $99 \%$ & $\operatorname{coses} 328.1$ \\
\hline (1) & 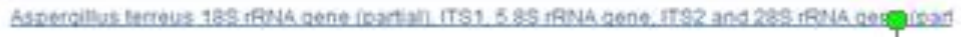 & 935 & 935 & $86 \%$ & 0.0 & $98 \%$ & ER837965.1 \\
\hline
\end{tabular}

(B) 


\begin{tabular}{|c|c|c|c|c|c|c|}
\hline Description & $\begin{array}{l}\text { Max } \\
\text { score }\end{array}$ & $\begin{array}{l}\text { Total } \\
\text { score }\end{array}$ & $\begin{array}{l}\text { Query } \\
\text { cover }\end{array}$ & $\begin{array}{l}\mathrm{E} \\
\text { value }\end{array}$ & Ident & Accession \\
\hline $\begin{array}{l}\text { Aspergillus terreus partial caM gene for } \\
\text { calmodulin, culture collection } \\
\text { CCF }<\text { CZE }>2911 \text {, exons } 1-5\end{array}$ & 767 & 767 & $76 \%$ & 0.0 & $99 \%$ & FR751432.1 \\
\hline $\begin{array}{l}\text { Aspergillus sp. CBS } 265.81 \text { calmodulin gene, } \\
\text { partial cds }\end{array}$ & 761 & 761 & $76 \%$ & 0.0 & $99 \%$ & FJ531221.1 \\
\hline $\begin{array}{l}\text { Aspergillus terreus partial caM gene for } \\
\text { calmodulin, culture collection } \\
\text { CCF }<C Z E>2539 \text {, exons } 1-5\end{array}$ & 754 & 754 & $75 \%$ & 0.0 & $99 \%$ & FR751433.1 \\
\hline $\begin{array}{l}\text { Aspergillus terreus isolate NRRL } 1923 \\
\text { calmodulin gene, partial ods }\end{array}$ & 719 & 719 & $80 \%$ & 0.0 & $96 \%$ & EF669538.1 \\
\hline $\begin{array}{l}\text { Aspergillus alabamensis strain UnB } \\
\text { calmodulin (cal) gene, partial cds }\end{array}$ & 713 & 713 & $70 \%$ & 0.0 & $99 \%$ & KM205224.1 \\
\hline
\end{tabular}

(C)

\begin{tabular}{|c|c|c|c|c|c|c|}
\hline Descretion & $\begin{array}{l}\mathrm{Nax} \\
\mathrm{sc00}\end{array}$ & $\begin{array}{l}\text { Total } \\
\text { scoen }\end{array}$ & $\begin{array}{l}\text { Owery } \\
\text { cover }\end{array}$ & E & seont & Acosestion \\
\hline 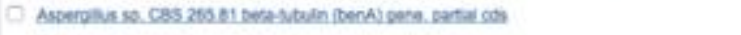 & 917 & 917 & $98 \%$ & 00 & $m$ & ENaninat \\
\hline 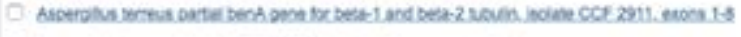 & 913 & 913 & $100 \%$ & 0.0 & 596 & ERMTSS42: \\
\hline 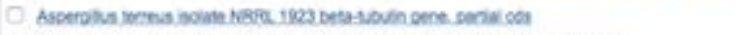 & $\infty 6$ & 861 & $100 \%$ & 0.0 & $97 \times$ & ERecosa4.1 \\
\hline 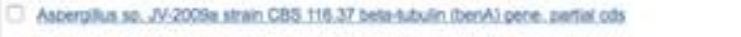 & en & 647 & $99 \%$ & 0.0 & $\sin$ & EASTHAS \\
\hline 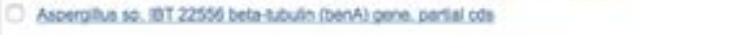 & 645 & 645 & $96 \%$ & 0.0 & $\operatorname{sox}$ & 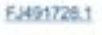 \\
\hline 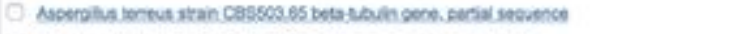 & 619 & 610 & $74 \%$ & $10-173$ & 565 & EVIATIT:1. \\
\hline 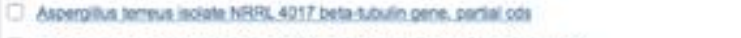 & 601 & 601 & 22\% & 50-168 & 896 & 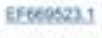 \\
\hline 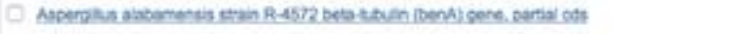 & set & 584 & $91 \%$ & so-163 & $890 \times$ & 20060851 \\
\hline 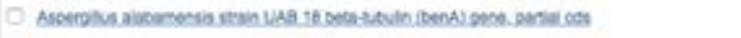 & set & 664 & 91\% & 6e-163 & ens & Butomas \\
\hline 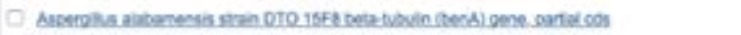 & sea & 584 & $91 \%$ & 5e-163 & ons & 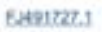 \\
\hline
\end{tabular}

\section{Capítulo Submetido para editora Springer:}

Leonora Rios de Souza Moreira, Camila Louly Corrêa, Helder Andrey da Rocha Gomes, Glaucia Emy Okida Midorikawa, Robert Neil Gerard Miller, Edivaldo Ximenes Ferreira Filho. The role of fungal transcriptome analysis and side-chain enzymes in sugarcane bagasse breakdown. In: Advances of Basic Science for Second Generation Bioethanol from Sugarcane and Their Impact on Technology, Springer.

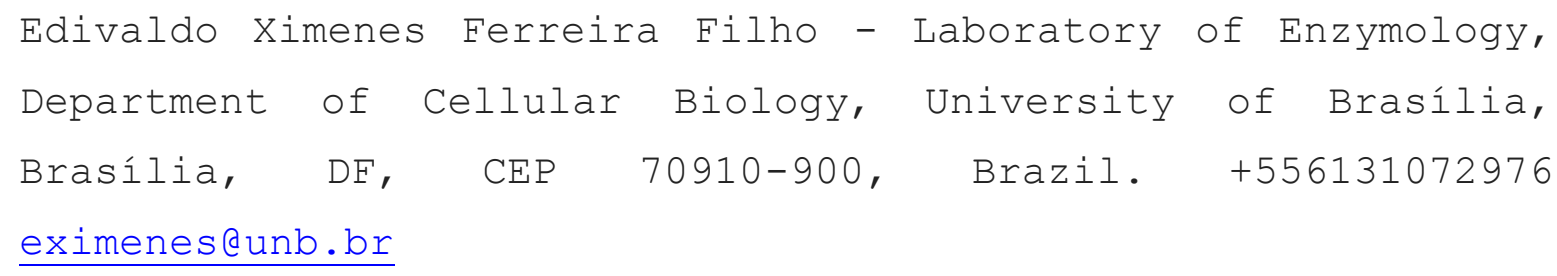


Robert Neil Gerard Miller - Laboratory of Microbiology, Department of Cellular Biology, University of Brasilia, Brasília, DF, CEP 70910-900, Brazil. +556131073048

robertmilleraunb.br

Leonora Rios de Souza Moreira - Laboratory of Enzymology, Department of Cellular Biology, University of Brasília, Brasília, DF, CEP 70910-900, Brazil. +556131072976

leonorarsmegmail.com

Helder Andrey da Rocha Gomes - Laboratory of Enzymology, Department of Cellular Biology, University of Brasilia, Brasília, DF, CEP 70910-900, Brazil. +556131072976 helderargomesegmail.com

Gláucia Emy Okida Midorikawa - Laboratory of Microbiology, Department of Cellular Biology, University of Brasilia, Brasília, DF, CEP 70910-900, Brazil. +556131073048

glauciaemy@gmail.com

Camila Louly Correa - Laboratory of Microbiology, Department of Cellular Biology, University of Brasília, Brasília, DF, CEP 70910-900, Brazil. +556131073048

milaloulyegmail.com

The role of fungal transcriptome analysis and side-chain enzymes in sugarcane bagasse breakdown 
Leonora Rios de Souza Moreirat, Camila Louly Corrêat, Helder Andrey da Rocha Gomes, Glaucia Emy Okida Midorikawa, Robert Neil Gerard Miller, Edivaldo Ximenes Ferreira Filho*

† These authors contributed equally to this work

* Corresponding author

\section{Abstract (MAX 250 palavras)}

Lignocellulose represents a main source of renewable energy for biofuel production. Within this context, sugarcane bagasse, which is a discarded by-product of sugarcane processing, is a rich source of lignin, hemicellulose and cellulose. Since sugarcane bagasse is a complex lignocellulosic structure, its complete enzymatic hydrolysis requires the action of an enzyme system of main- and sidechain enzymes. The xylan component in sugarcane bagasse is arabinosylated at the positions $\mathrm{C}-2$ and/or $\mathrm{C}-3$ and esterified with ferulic acid at the c-5 position. Accessory enzymes such as $\alpha$-arabinofuranosidase and feruloyl esterase are responsible for enhanced accessibility and enzymatic hydrolysis of xylan. Under industrial conditions, numerous filamentous fungi can secrete enzymes or enzyme complexes belonging to the glycosyl hydrolases, carbohydrate esterases and polysaccharide lyases for the hydrolysis of cellulose, hemicellulose and lignin. Next generation sequencing approaches for whole genome and transcriptome analysis enable both identification of novel genes and isoforms in fungi encoding these hydrolytic enzymes and increase our understanding of mechanisms involved in gene expression induction in the presence of plant cell wall or its metabolic products. Downstream application will accelerate strain 
improvement for increased enzymatic efficiencies and

hydrolytic enzyme cocktail development, contributing to reducing cellulosic bioethanol production costs.

Keywords: Arabinofuranosidase, Feruloyl-esterase, side-chain enzymes, transcriptome, sugarcane bagasse.

\section{Introduction}


In times of growing concern over the limitation of fossil fuels, the utilization of renewable resources such as ethanol has become of great interest. The increased demand for energy, geo-political factors, and environmental pressures have alarmed the scientific community, economists and governments to evaluate the potential of cellulosic ethanol as a sustainable, economic and ecofriendly alternative to gasoline. One of the main sources of renewable energy for biofuels is the conversion of plant-derived carbohydrates into bioethanol. In this context, sugarcane bagasse is an excellent raw material for second generation ethanol production in countries such as Brazil, India and China, where this biomass residue is generated in huge amounts every year (Goldemberg, 2007, Chandel et al., 2012, Chandel et al., 2013, Souza et al., 2013a).

Sugarcane bagasse (or bagasse as it is generally called) is a fibrous residue of cane stalks left over after the crushing and extraction of the juice from the sugarcane. This residue is produced in large quantities by sugar and alcohol industries. In general, 1 ton of sugarcane generates $280 \mathrm{~kg}$ of bagasse (Sun et al., 2004b, Pandey et al., 2000).

The stockpiled bagasse is of low economic value and constitutes an environmental problem to sugar mills and surrounding districts, especially if stocked for extended periods, due to the risk of spontaneous combustion occurring within the pile (Sun et al., 2004a). Chemically, about 40-50\% of the dry residue of sugarcane corresponds to the glucose polymer cellulose, most of which is in a crystalline structure. Hemicelluloses, which include xylans, mannans, arabinans and galactans, represent the second most abundant 
fraction (25-35\%). The remainder is mostly lignin and lesser amounts minerals, waxes, and other compounds (Jacobsen and Wyman, 2002). Other study reports 42\% cellulose, 22\% lignin, 28\% hemicelluloses and 8\% of cane wax and organic acid (Beukes et al., 2008). Chemical composition varies across the different plant tissues of sugarcane stalks, with greater lignin and cellulose content in epidermal tissues in comparison with nodes and internodes (Brienzo et al., 2014). Because of its low ash content (2.3\%), bagasse offers advantages for application as a novel material for industries when compared with crop residues such as rice straw, which has 13.3\% ash content (Sun et al., 2004a).

Saprophytic filamentous fungi are known for their potential in decomposition of plant lignocellulosic biomass to simple fermentable sugars. A wide variety of fungi, especially those belonging to the Basidiomycete and Ascomycete classes, have been the target of investigation by the second generation bioethanol industry given the quantity and variety of secretory enzymes or enzyme complexes that can be produced which are applicable in hydrolysis of cellulose, hemicellulose and lignin (Couturier et al., 2012). Numerous studies have shown that GH expression in filamentous fungi generally requires induction. For this, lignocellulosic materials can be used as carbon source in the culture medium, enabling fungal growth and the induction of complex cellulase and hemicellulase enzymes (Sørensen et al., 2011). The enzymes involved in the degradation of plant polysaccharides can be divided into different glycosidase families based on the amino acid sequences structurally related to the catalytic module (CAZy database). These comprise at least 35 families of glycosyl hydrolases (GH), three families of 
carbohydrate esterases (EC) and six families of polysaccharide lyases (PL) (Battaglia et al., 2011). In addition to the wide variety of enzymes with different specificities that are needed to degrade components of lignocelluloses, additional proteins have also been identified that contribute to the degradation of the plant cell wall, such as glycosyl hydrolase family members (GH 61) and expansins and swollenins (Van Dyk and Pletschke, 2012).

\section{Sugarcane bagasse structure}

The crop is today the most efficient natural raw material for first generation bioethanol production by distillation, with consumption of fossil energy during processing much lower than that required for maize (Macedo et al., 2008). One of the byproducts generated during processing is sugarcane bagasse, which is usually burned in boilers to produce steam and electricity, providing the energy needed to meet the requirements of the distillation process. Efficient cogeneration technologies for the production of bioethanol still result in surplus bagasse, which, in addition to use as a fuel source for electricity generation, can be applied as a primary material for production of cellulosic bioethanol (a second generation biofuel) or other biological-based products (Ensinas et al., 2007).

Many studies have been conducted to characterize the hemicellulose and lignin fractions present in the sugarcane bagasse cell wall. As shown in table 1 , xylose represents the major monosaccharide present in hemicellulose, followed by arabinose. 
In bagasse, the hemicellulose is composed of a xylan polymer onto which other groups are bound, with glucuronic acid and arabinose most commonly encountered (Lavarack et al., 2002). The most abundant hemicellulose in annual plants is arabinoxylan which has a classical structure, with a backbone of $\beta-(1,4)$ linked xylosyl residues substituted with arabinose and 4-0-methyl-D-glucuronic acid at C-2 and/or C-3 of the main chain (Xu et al., 2006, Peng et al., 2009). The higher arabinose content present in bagasse indicates a higher degree of branching of the xylan chains, and so higher solubility of the polymers. (Sun et al., 2004a). Arabinose plays an important role in the cross-links between hemicelluloses and lignin (Sun et al., 2011).

Degraded hemicelluloses from sugarcane bagasse also contain minor quantities of bound lignin and hydroxycinnamic acids, such as ferulic and p-coumaric acids (Xu et al., 2006). In the lignin fraction, ferulic acid, 3-(3-methoxy-4hydroxyphenyl)-2-propenoic acid and p-coumaric acid are the major hydroxycinnamic acids found in the cell walls (Xu et al., 2005). Ferulic acid, being one of the abundant hydroxycinnamic acids in plant cell walls, is a very attractive phenolic compound, as it can be used as an antioxidant or be transformed by microbial conversion into "natural" vanillin, an expensive flavor for food, cosmetic and pharmaceutical industries (Levasseur et al., 2005). Table 2 shows the content of phenols of the associated lignin in isolated hemicellulosic fractions.

Ferulic and p-coumaric acids are found covalently linked to polysaccharides by ester bonds and to components of lignin by ester or ether bonds. A considerable proportion of pcoumaric acid is known to be esterified with lignin, while 
ferulic acid is extensively etherified with lignin (Xu et al., 2005, Sun et al., 2011). During the cell wall biosynthesis, ferulated arabinoxylans are extensively crosslinked by the coupling of ferulic into diferulates and by the copolymerisation of ferulate and diferulates with monolignols to form polysaccharide-lignin complexes (Ralph et al., 2004). Ferulic acids, which are associated both with lignin by ether bond and with hemicelluloses by ester linkage contribute to the cell wall cross-linking (Xu et al., 2005).

Considering the biotechnological potential of lignocellulosic fungi, where applications include the food and feed industries, textile, pulp and paper treatment, and in particular the biofuel industry, a complete understanding is needed regarding substrate-specific enzyme expression, regulatory mechanisms and enzyme expression levels according to specific metabolic pathways. Through functional genomics, or transcriptomics, it is now possible to predict the biotechnological potential of particular fungal strains according to the identification of genes and comparison of gene expression levels under different treatments. Although numerous studies have been conducted to characterize enzymes involved in the degradation of lignocellulose, understanding is still incomplete in relation to the transcription and regulation of genes encoding these enzymes. Studies on the mechanisms of regulation and expression of such genes in candidate fungi are thus essential for the development of viable second generation biofuel processes. 
Table 1: Monosaccharide contents in the hemicellulosic fraction from sugarcane bagasse

\begin{tabular}{|c|c|c|c|c|c|c|c|}
\hline Method of extraction & $\begin{array}{l}\text { Arabinos } \\
\text { e }\end{array}$ & $\begin{array}{l}\text { Rhamnos } \\
\text { e }\end{array}$ & Xylose & Mannose & $\begin{array}{l}\text { Galactos } \\
\text { e }\end{array}$ & Glucose & Ref. \\
\hline $\begin{array}{lcr}\text { Water } & \text { soluble } & \text { hemi- } \\
\text { cellulose } & \text { and } & \text { lignin } \\
\text { fraction } & & \end{array}$ & 12.83 & 1.25 & 37.38 & 8.07 & 11.61 & 28.86 & $\begin{array}{l}(\text { Sun et al., } \\
\text { 2004a) }\end{array}$ \\
\hline $\begin{array}{lr}\text { Alkali-soluble } & \text { hemi } \\
\text { cellulose and lignin } \\
\text { fraction }\end{array}$ & 12.57 & 0.42 & 80.60 & 0.40 & 1.83 & 4.18 & $\begin{array}{l}(\text { Sun et al., } \\
\underline{2004 a)}\end{array}$ \\
\hline $0.5 \mathrm{M} \mathrm{NaOH}$ and $0.5 \mathrm{M} \mathrm{H}_{2} \mathrm{O}_{2}$ & 10.40 & 0.44 & 78.98 & 0.32 & 1.95 & 7.93 & $\begin{array}{l}\text { (Sun et al., } \\
2004 a)\end{array}$ \\
\hline $\begin{array}{l}\text { Alcohol insoluble residue } \\
\text { hydrolyzed with } \mathrm{H}_{2} \mathrm{SO}_{4}\end{array}$ & 2.4 & N.D & 33.5 & N.D & 0.9 & 59.8 & $\begin{array}{l}\text { Souza et } \\
\text { al.,2013a) }\end{array}$ \\
\hline Acid hydrolysates & 1.80 & $\mathrm{ND}$ & 20.30 & ND & 0.65 & 36.74 & $\begin{array}{l}\frac{\text { (Szczerbowsk }}{\text { i et al., }} \\
\underline{2014)}\end{array}$ \\
\hline $\begin{array}{l}\text { Dewaxed bagasse with } 1 \mathrm{M} \mathrm{NaOH} \\
\text { aqueous solution at } 40^{\circ} \mathrm{C} / 18 \\
\text { h }\end{array}$ & 11.6 & 6.5 & 78 & 1.4 & 0.3 & 2.2 & $\frac{(\mathrm{Xu} \text { et al., }}{\underline{2006)}}$ \\
\hline $\begin{array}{l}\text { Precipitated with } 30 \% \\
\text { ethanol and solubilized with }\end{array}$ & 5.61 & $\mathrm{ND}$ & 92.98 & traces & ND & 1.35 & $\begin{array}{l}\text { (Peng et } \\
\text { al., 2009) }\end{array}$ \\
\hline
\end{tabular}




\begin{tabular}{|c|c|c|c|c|c|c|c|}
\hline $3 \% \mathrm{NaOH}$ & & & & & & & \\
\hline $\begin{array}{l}\text { Precipitated with } 15 \% \\
\text { ethanol and solubilized with } \\
1 \% \mathrm{NaOH}\end{array}$ & 12.13 & 0.13 & 2.77 & 0.53 & 2.77 & 5.20 & $\begin{array}{l}\text { (Peng et } \\
\text { al.,2009) }\end{array}$ \\
\hline
\end{tabular}

*ND=not determined

Table 2: The percent of phenolic acids of the lignin fraction associated to hemicellulose from sugarcane bagasse

\begin{tabular}{|c|c|c|c|c|c|c|c|}
\hline Method of extraction & pHBA* & $\begin{array}{l}\text { Vanilli } \\
\text { c acid }\end{array}$ & $\begin{array}{l}\text { Vanilli } \\
\text { n }\end{array}$ & $\begin{array}{l}\text { Syringic } \\
\text { acid }\end{array}$ & $\begin{array}{l}\mathrm{p}- \\
\text { coumaric } \\
\text { acid }\end{array}$ & $\begin{array}{l}\text { Ferulic } \\
\text { acid }\end{array}$ & Ref. \\
\hline $\begin{array}{l}\text { Water soluble hemi- cellulose } \\
\text { and lignin fraction }\end{array}$ & 0.59 & 0.03 & 1.05 & 0.04 & 0.1 & 0.06 & $\begin{array}{l}\text { (Sun et al. } \\
\text { 2004a) }\end{array}$ \\
\hline $\begin{array}{l}\text { Alkali-soluble hemi cellulose } \\
\text { and lignin fraction }\end{array}$ & 0.10 & 0.008 & 0.36 & 0.02 & 0.011 & 0.03 & $\begin{array}{l}\text { (Sun et al. } \\
2004 a)\end{array}$ \\
\hline $0.5 \mathrm{M} \mathrm{NaOH}$ and $0.5 \mathrm{M} \mathrm{H}_{2} \mathrm{O}_{2}$ & 0.01 & 0.01 & 0.35 & 0.02 & 0.011 & 0.01 & $\begin{array}{l}\text { (Sun et al. } \\
\text { 2004a) }\end{array}$ \\
\hline Lignin fraction solubilized & 1.71 & 11.14 & 17.66 & 3.49 & $0.55 * \star$ & $0.55 * \star$ & (Sun et al. \\
\hline
\end{tabular}




\begin{tabular}{|l|l|l|l|l|l|l|}
\hline $\begin{array}{l}(80 \% \mathrm{~d} \text { dioxane solution with } \\
\left.0.05 \mathrm{M} \mathrm{HCl}-85^{\circ} \mathrm{C} / 4 \mathrm{~h}\right) .\end{array}$ & & & & & \\
\hline $\begin{array}{l}\text { Dewaxed bagasse with } 1 \mathrm{M} \mathrm{NaOH} \\
\text { at } 40^{\circ} \mathrm{C} / 18 \mathrm{~h}\end{array}$ & 0.007 & 0,018 & 0.070 & 0.018 & 0.70 & 0.42 \\
\hline
\end{tabular}

*p-hydroxybenzoic acid

**As total cinnamic acid. 


\section{Genomics applied to the study of lignocellulosic fungi}

Whole genome sequence analysis for lignocellulosic fungi is enabling molecular mechanisms controlling natural processes to be better understood, with downstream application in strain modification through genetic engineering. The first major milestone in fungal genomics was the sequencing of the yeast genome Saccharomyces cerevisiae (Goffeau et al., 1996). In the case of lignocellulosic fungi, the genomes of numerous species have now been completely sequenced or re-sequenced, contributing considerably towards understanding of lignocellulosic bio-processes. Greater knowledge will enable improved hydrolytic enzyme cocktail development and downstream biotechnological applications.

Trichoderma is an important filamentous fungal genus for industrial bioprocesses, with numerous species capable of secreting cellulosic enzymes at high concentrations. T. reesei (teleomorph Hypocrea jecorina) has been the focus of whole genome sequencing and re-sequencing projects as the model system for the genus for furthering understanding of lignocellulose degradation. The complete genome sequence of $T$. reesei was published by Martinez et al. (2008), with $34.1 \mathrm{Mb}$ of sequence distributed over seven chromosomes and a total of 9,143 gene models. Analysis of the T. reesei genome identified 200 genes that encode glycosyl hydrolases, 103 glycosyl transferases, 36 carbohydrate binding modules, three polysaccharide lyases, seven genes encoding cellulases and 16 genes encoding hemicellulases (Martinez et al., 2008).

T. virens (teleomorph Hypocrea virens) and T. atroviride (teleomorph Hypocrea atroviridis) are also promising species in terms of holocellulosic enzyme secretion. Whole genome sequences have been completed for both species, with $T$. virens and $\mathrm{T}$. atroviride genome sizes at $38.8 \mathrm{Mb}$ and $36.1 \mathrm{Mb}$, 
respectively. As well as possessing greater genome sizes than T. reesei, the total numbers of predicted genes in these two species also outnumber those in $T$. reesei, with 12,428 genes predicted in $T$. virens and 11,865 in $T$. atroviride. Genes involved in hydrolysis of cellulose and hemicellulose total 260 in T. virens and 257 in T. atroviride, again outnumbering the total within these categories in $T$. reesei (Kubicek et al., 2011). Surprisingly, the $T$. reesei genome contained the lowest recorded number of holocellulases encoding genes when compared with other fungal genomes, comprising a total of 130 genes located in 25 clusters for the cellulose and hemicelluloses efficient degradation (Martinez et al., 2008). Additional Trichoderma species also promising for production of hydrolytic enzymes include $T$. Iongibrachiatum and $T$. harzianum. Phylogenetically close to T. reesei, T. longibrachiatum has the smallest reported genome within the genus, totaling $32.24 \mathrm{Mb}$ and 10,792 predicted genes. T. harzianum, by contrast, has the largest genome size to date within the genus, $40.98 \mathrm{Mb}$ in size, with 14,095 predicted genes (Srivastava et al., 2014).

Fungal species of the genus Aspergillus are also promising secretors of enzymes that degrade lignocellulose, especially hemicellulose. A. nidulans (teleomorph Emericella nidulans), historically considered the model species for the genus with complete elucidation of its sexual cycle, has been the focus of whole genomic sequencing (Galagan et al., 2005). The species $A$. oryzae and $A$. niger are classified as GRAS status (Generally Regarded as Safe), with wide employment in industrial applications (Machida et al., 2005, Pel et al., 2007). Whole genome sequences for these two species are available in the genome databases at the Broad Institute (Broad-Institute, 2015) the National Center for Biotechnology 
Information (NCBI, 2015) and the Aspergillus Genome Database (AspGD, 2015).

The A. nidulans genome, with a total length of $30.06 \mathrm{Mb}$ and 9,396 predicted genes, contrasts with the larger genomes of $A$. oryzae and $A$. niger, with respective genome sizes at $37.12 \mathrm{Mb}$ and $37.2 \mathrm{Mb}$, and gene models totaling 12,336 and 11,200 (Machida et al., 2005, Pel et al., 2007). From a total of 186 predicted cazy-encoding genes in A. nidulans, 159 genes have been reported to group in the $\mathrm{GH}$ family, 19 in the PL family and 8 genes grouping in the CE family. In the case of A. oryzae and A. niger, 217 and 171 cazy-encoding genes have been predicted, respectively, with 183 grouped in the GH family, 20 in the $\mathrm{PL}$ family and 14 in the $\mathrm{CE}$ family for $A$. oryzae and 155, 8 and 8 genes grouped in families GH, PL and $C E$, respectively, for $A$. niger. Comparative analyses of $A$. oryzae, A. nidulans and A. flavus suggest that a number of mechanisms are responsible for the differences in genome size and gene numbers between Aspergillus species, with genome and segmental duplication having resulted in genome size differences, and horizontal gene transfer shaping genomes between donor and recipient strains (Gibbons and Rokas, 2013, Khaldi and Wolfe, 2008, Mallet et al., 2010). Whole genome sequences have also been generated and annotated for $A$. terreus, $A$. flavus and $A$. fumigatus. $A$. terreus has a genome size of 29.33Mb with 10,406 predicted genes (Broad-Institute, 2015). By contrast, the A. flavus genome is estimated to be similar in size to A. oryzae, with 36.8 MB coding 12,424 predicted genes (Gibbons and Rokas, 2013). Similar to $A$. nidulans, $A$. fumigatus has a genome size of $29.2 \mathrm{Mb}$, encoding 9906 predicted genes (Nierman et al., 2005, Payne et al., 2006). A comparison between these two genomes shows that $A$. fumigatus also has a similar number of cazy-encoding genes to A. nidulans, with 155 genes clustered in the GH family, eight 
genes grouped in PL family and eight genes grouped in the EC family (Pel et al., 2007).

\title{
3.1. Functional genomics applied to the study of lignocellulosic fungi
}

\begin{abstract}
Functional genomics, or transcriptomics, which investigates the transcribed portion of the genome, has applications in both gene function identification and gene expression analysis. Large-scale comparative transcriptome analysis enables the identification of differentially expressed genes that are involved in conferring or regulating essential characteristics for the development and adaptation of a microorganism to its environment (Mardis, 2008). Although filamentous fungi have been widely exploited for enzyme production under simultaneous saccharification and fermentation conditions (SSF), little research has been conducted on gene expression control mechanisms under SSF. Whilst studies have shown that the expression of certain genes involved in the production of hydrolases are controlled at the transcriptional level, events following transcription and translation are less well documented in fungi (Lubertozzi and
\end{abstract} Keasling, 2009).

Applications of transcriptomics in fungi in relation to identification of genes involved in the production and regulation of hydrolytic enzymes has been the focus of considerable research for downstream application in enzymes industries. In the late 1990s, the first transcriptome analyses in target fungi such as Trichoderma and Aspergillus focused on large-scale sequencing of ESTs (Expressed Sequenced Tags). In 2002, the transcriptome of $T$. reesei was analyzed in relation to glucose-dependent expression regulation, with 1,151 unigenes identified among a set of 2,835 ESTs (Chambergo 
et al., 2002). A similar study was conducted on A. oryzae, where from approximately 2,000 selected ESTs, microarray analyses revealed that transcripts in cultures supplemented with glucose are highly dependent on the glycolytic pathway (Maeda et al., 2004). Since then, the total number of available ESTS deposited in the NCBI GenBank database has increased extensively. In the case of Aspergillus species which are the focus of hydrolytic enzyme production, 19,830 ESTs are currently available for $A$. oryzae, 16,394 for $A$. nidulans, 14,195 for A. niger and 10.415 for $A$. terreus. For Trichoderma species, a more expressive number of ESTs are available in Genbank, reflecting the long-term recognized biotechnological importance of this genus. A total of 44,966 ESTs are available for $T$. reesei, 35,475 for T. virens, 35,125 for T. atroviride, 19,914 for T. harzianum and 1,799 ESTs for T. longibrachiatum.

Transcriptome analyses for lignocellulolytic species of Trichoderma and Aspergillus have focused on understanding the dynamics of genes involved in the synthesis of enzymes of industrial value. Transcription profiles after growth on specific culture media has contributed to the identification of novel differentially expressed genes. For example, analysis in $T$. reesei during limiting culture conditions with cellulose, lactose and sophorose has enabled characterization of 5,131 unigenes, of which 12 genes encode endoglucanases (cel74a, cel61b and cel5b), $\beta$-glucosidase (cel1b, cel3b, cel3c, cel3d and cel3e), hemicellulase (axe2 and ABF2) and genes containing cellulose-binding domains (CIP1 and CIP2) where Northern blot and comparative microarray analyses of two strains of $T$. reesei (QM6a and RL-P37) also indicated that these genes are highly regulated in the presence of cellulose and sophorose (Foreman et al., 2003). 
Similarly, transcriptomic analysis in $A$. niger when cultivated on media supplemented with glucose, maltose, xylan, xylose, sorbitol and lactose enabled the identification of 5,108 unigenes from 12,820 ESTs and subsequent Gene Ontology (GO) classification of 2,549 predicted protein products revealed 32\% with hydrolytic activity (Semova et al., 2006).

Given that lignocellulolytic fungi produce hydrolytic enzymes according to available carbon source, a number of studies have focused on understanding the transcriptional dynamics in relation to cell wall hydrolysis of agroindustrial residues. In order to understand how genes encoding hydrolytic enzymes in $A$. niger are influenced by growth on sugarcane bagasse as carbon source, microarray analysis of 3,700 genes from $A$. niger enabled identification of 18 genes encoding cellulases which were upregulated in response to sugarcane bagasse compared to fructose. A similar response was observed with 21 genes encoding hemicellulases. As seven genes encoding predicted transporters also showed increased expression in response to bagasse and repression in the presence of glucose, this data suggested that these genes are xylose transporters (Souza et al., 2011). Continuing this work, a differential expression of genes in A. niger regulated by the transcriptional activator XlnR and its close homolog, AraR, witch controls the main collulolytic and hemicellulolytic systems in response to growth on sugarcane bagasse. A total of 1,024, 439, 109 and 176 genes were significantly and exclusively upregulated in $A$. niger wild type, $\Delta x l n R, \Delta a r a R$ and $\Delta a r a R x l n R$ strains, respectively, whilst 1,553, 770, 555 and 246 genes were exclusively down-regulated. The considerable numbers of differentially expressed genes observed indicated the involvement of transcriptional regulators controlling metabolism in response to this complex substrate (Souza et al., 2013b). 
Next Generation Sequencing (NGS) technologies applied in transcriptome analysis enable large scale, precise characterization of unigenes and their expression (Mardis, 2008). Illumina RNA-Seq is a shotgun method appropriate for transcriptome sequencing, where CDNA is fragmented mechanically to produce small overlapping fragments that can cover the entire transcriptome. This approach allows identification of novel genes and isoforms involved in protein production under contrasting conditions. This massively parallel sequencing technology, in addition to enabling identification of novel genes and isoforms involved in protein production under contrasting conditions, offers a sensitivity appropriate for characterization of all transcripts, including even those with low expression levels (Garber et al., 2011), in contrast to previous approaches such as SAGE and microarrays. In this context, NGS technologies are applicable to identification of genes involved in cell wall degradation pathways as well as understanding transcriptional control mechanisms in lignocellulolytic fungi with biotechnological potential.

Genes required for growth and enzymatic activity on polymers such as cellulose have been analyzed by NGS in the model organism Neurospora crassa, with with two uncharacterized zinc binuclear cluster transcription factors, crll and crl2, identified as responsible for the induction of the major genes encoding cellulases and hemicellulases (Coradetti et al., 2012, Znameroski et al., 2012). Similarly, in the anaerobic rumen fungus Neocallimastix patriciarum, NGS approaches allowed identification of genes involved in the degradation of different lignocellulosic materials (Wang et al., 2011). In the case of the basidiomycete fungus Phanerochaete carnosus, NGS-based analyses during culture on different wood substrates revealed greater abundance of 
transcripts encoding enzymes with activity in lignin degradation than those coding for enzymes involved in degradation of other carbohydrates (MacDonald et al., 2011).

NGS-based transcriptional profiling of genes encoding enzymes with carbohydrate activity in Myceliophthora thermophila and Thielavia terrestris was also investigated following growth on barley straw, alfalfa straw and glucose. Upregulation of genes involved in lignocellulose degradation was observed following exposure to polysaccharides derived from these biomass substrates (Berka et al., 2011). Delmas et al. (2012) reported the application of SOLiD® RNA-Seq NGS to analyze the transcriptome of $A$. niger. The study found that approximately 19\% of the total mRNA is involved in gene expression related to enzymes that degrade plant cell wall after 24 hours exposure to wheat straw. This is a considerable enrichment of CAZy group genes, given that they represent only 2.5\% of the coding genome. The numerous categories of expressed CAZy genes during exposure to wheat straw reflected the complexity of the carbohydrates present in the substrate. Interestingly, approximately 65\% of the mRNA from CAZy groups originated from genes that encode only five enzymes families, namely GH7, 11, 61 and 62 (cellobiohydrolases, xylanases, $\alpha-$ arabinofuranosidases and polysaccharide monooxygenases, respectively) and CE1 (acetyl xylan esterases). Based on transcript abundance, these five categories of encoded enzymes were considered to provide the complete spectrum of activities for straw degradation. Catabolic repression by glucose addition to wheat straw cultures was also reported to repress CAZy gene expression after just 5 hours, with CAZy gene mRNA reduced to just $1 \%$ of the total RNA. Analysis has shown that the predominant induction model in fungal systems proposes a basal expression of small amounts of hydrolases that initiates degradation of complex polysaccharides, thus producing 
inducing compounds which provoke a complete transcription response (Foreman et al., 2003).

Comparative studies of the transcriptome of different lignocellulolytic fungi have shown that as well as repression of genes encoding hydrolytic enzymes in the presence of glucose, induction of these genes occurs in the presence of compounds derived from the material present in the plant cell wall or its metabolic products. Analysis of Illumina RNAseqderived transcriptome sequences of $T$. reesei and $A$. niger, grown in the presence of glucose or wheat straw as carbon source, revealed that $T$. reesei uses an enzyme machinery similar to that of $A$. niger, suggesting that both microorganisms employ conserved strategies for the depolymerization of lignocellulosic substrates. In the case of T. reesei, after 48 hours growth on glucose, mRNA of genes encoding CAZy enzymes represented only $1.14 \%$ of the total RNA. By contrast, following $24 \mathrm{~h}$ incubation in the presence of wheat straw, genes that expressed mRNA for $\mathrm{GH}$ families ( $\beta-$ glucosidase, xylanase and cellobiohydrolase CEL7A), AA9 families (auxiliary oxidoreductases) and EC families (acetyl xylan esterases) represented around 65\% of the expressed CAZy genes. Similar changes in expression of CAZy enzyme encoding genes in relation to carbon source were observed in $A$. niger (Delmas et al., 2012, Ries et al., 2013).

Recently, the CAZy repertoire in $T$. reesei based on computational and manual approaches was revised and expanded, which resulted in a total of 201 genes encoding glycosyl hydrolases, 22 genes encoding carbohydrate esterases and 5 genes encoding polysaccharide lyases. Most of the genes that express cellulases and hemicellulases characterized $T$. reesei are regulated by carbon source available, ensuring production of only hydrolytic enzymes necessary for degradation of the particular substrate. Analysis of transcription factors in $T$. 
reesei that are involved in expression regulation of genes encoding cellulases and hemicellulases have also been reported. These include positive regulators such as XYR1, ACE2 and the complex HAP2/3/5, as well as negative regulators such as ACE1 and the catabolic repressor CRE1 (Häkkinen et al., 2012). The transcription factor XYR1 (xylanase regulator 1) is recognized as a main transcriptional activator of genes encoding hydrolases such as xyn1, xyn2, bxl1, cbh1, cbh2 and egl1 (Portnoy et al., 2011).

In addition, analysis showed that XYR1 and CRE1-derived regulation of expression of genes encoding cellulases and xylanases is carbon source dependent (Castro et al., 2014)

Castro et al., (2014) recently investigated the T. reesei transcriptome following growth on cellulose, sophorose and glucose media cultures. Analysis of NGS data enabled hierarchical clustering of 2.060 differentially expressed genes, when comparing expression on cellulose against glucose, sophorose against cellulose and glucose against sophorose. Three possible regulators were identified, with 123 genes modulated by cellulose, 154 genes modulated by sophorose and 402 genes modulated by glucose. Comparison of the top 10 most differentially expressed genes following growth on the three carbon sources was conducted in order to evaluate the specific regulation of each carbon source. The ten most upregulated genes in cellulose included glycosyl hydrolases family members (GH5, GH31, GH16), carbohydrate esterase (EC 5), a major facilitator superfamily permease (MFS) and five proteins with unknown function. For sophorose, one hydrolase (GH76), four oxidoreductases, two permeases (MFS), and three proteins with unknown function were identified. As expected for growth on glucose, the top 10 most differentially expressed genes were not related to hydrolytic enzyme-encoding genes. 


\subsection{Functional genomics analysis of lignocellulosic fungi on sugarcane bagasse}

Brazil plays an important role today in meeting the world's demands for bioethanol, with sugarcane-derived ethanol accounting for approximately 30\% of the world's production. Further increases in efficiency in ethanol production from this crop will rely upon improvements in both agricultural production and industrial processes. Sugarcane bagasse contains one third of the total energy content of the sugarcane plant, with application today in energy provision for bioethanol production plants (Cerqueira Leite et al., 2009). The ongoing development of efficient technologies for the hydrolysis of sugarcane bagasse for production of second generation ethanol will further exploit the energy content of this material. Considering the high cost of the major industrial enzymes employed today in the hydrolysis of sugarcane bagasse (cellulases and hemicellulases), an increased understanding of the mechanisms controlling their expression in candidate lignocellulosic fungi is important for downstream efficient biotechnological enzyme production.

In this context, (Horta et al., 2014) characterized the transcriptome of the fungus $T$. harzianum grown on sugarcane bagasse using NGS RNA-seq technology in order to identify genes involved in degradation of cellulose and hemicellulose, together with accessory genes involved in the depolymerization of the biomass. A total of 487 CAZymes were identified from the transcriptome, with 23 genes encoding glycosyl hydrolase family proteins involved in the depolymerization of cellulose and a further 22 glycoside hydrolase encoding genes involved in the hemicellulose breakdown. A total of 164 contigs were also classified as potentially related to the degradation of biomass. A systematic synergism between different enzyme 
classes for specific metabolic pathways in $T$. harzianum was also identified. These pathways included metabolism of various sugars associated with the depolymerization of this biomass.

Similarly, functional genomics analysis of a number of promising lignocellulolytic fungi are being conducted at the University of Brasilia, following growth on abundant organic residues that include sugarcane bagasse, soybean hulls and cotton louse. RNA-seq analysis of a strain of $A$. oryzae cultivated on sugarcane bagasse as carbon source enabled identification of a total of 207 cazy-encoding genes in liquid culture state and 222 genes in semi-solid culture, from a total of 7,126 genes expressed by the fungus across different cultivation treatments (Midorikawa, G.E.O., unpublished). Similarly, in the case of RNA-seq analysis of a local strain of $A$. terreus grown on sugarcane bagasse, 102 cazy-encoding genes were expressed during liquid culture state, out of a total of 6,200 identified genes (Correa, C. L., unpublished).

\section{Enzymatic attack on the sugarcane bagasse structure}

Enzymatic hydrolysis of plant cell wall is known to require an arsenal of enzymes, including cellulases, hemicellulases and pectinases. A kinetic model for the interaction between cell wall components and a consortium of enzyme systems needs the analysis of several factors, including the involvement of different types of chemical linkages and the environment that surrounds the cell wall structure. Recalcitrance to saccharification is a major limitation for the conversion of lignocellulosic biomass to valuable end products (Siqueira and Filho, 2010, Varnai et al., 2014).

As a recalcitrant structure, the plant cell wall demands a broad range of hydrolytic enzymes acting together for its 
complete degradation. The complexity and heterogeneity of the holocellulose structures demands the synergistic action of main- and side- chain attacking enzymes with different specificities for its complete hydrolysis (Andreaus et al., 2008, Moreira et al., 2012). Synergism is only detected when the total products formed by two or more enzymes acting together exceed the arithmetic sum of the products formed by the action of each individual enzyme. Homosynergy can be classified as the interaction between two or more different types of side-chain enzymes, or between two or more types of main-chain enzymes (Coughlan et al., 1993). Heterosynergy is defined as the interaction between side-chain and main-chain enzymes (Andreaus et al., 2008).

Enzyme systems with low substrate specificity act in synergism with enzymes with strict substrate specificity, leading to a more efficient catalytic process. Within this context, enzymes that cut specific sites in the plant cell wall are also important tools for understanding the structure and function of the cell wall (Siqueira and Filho, 2010).

The plant cell wall complexity and heterogeneity requires a large spectrum of exo- and endo-enzymatic activities. In this context, two side-chain enzymes appear as key enzymes to the full degradation of sugarcane bagasse (Fig.1), Feruloyl esterase, which are responsible for cleaving the ester-link between the polysaccharides in the main chain of xylans or pectins; and $\alpha$-arabinofuranosidase that catalyze the hydrolysis of terminal $\alpha-\mathrm{L}-1,2-, \quad \alpha-\mathrm{L}-1,3-$ and $\alpha-\mathrm{L}-1,5-$ arabinofuranosyl residues of poly and oligosaccharides (Moreira et al., 2011).

\subsection{Feruloyl Esterases}


Feruloyl esterases also known as ferulic acid esterases, cinnamoyl esterases and cinnamic acid hydrolase (FAEs, E.C. 3.1.1.73), a subclass of the carboxylic acid esterases (E.C. 3.1.1.1). These have gained importance in biofuel, medicine and food industries due to their capability of hydrolyzing carbohydrate esters in wood polymers and synthesizing high added-value molecules through esterification and transesterification reactions (Udatha et al., 2012, Crepin et al., 2003).

An enzyme that hydrolyzes ester linkages of ferulic acid from starch-free wheat bran and from a soluble ferulic acidsugar ester, isolated from wheat bran was first reported as a component of the cellulolytic and xylanolytic systems of Schizophyllum commune (Mackenzie and Bilous, 1988). Since the 1990s, a broad range of FAEs have been purified and characterized from a wide range of microorganisms, including bacteria and fungi. Many enzymes from the genera Aspergillus, Clostridium and Penicillium have been studied (de Vries et al., 2002, Topakas et al., 2007, Moreira et al., 2011). FAEs from different microbial sources present great variations in physiochemical properties, concerning to their molecular masses, pI, optimum $\mathrm{pH}$ and temperatures, kinetic parameters (revised by Wong, 2006) .

FAEs are responsible for cleaving the ferulic acid bridges and eliminating the crosslinks between polysaccharides and the lignin structure. These polysaccharides, which complex together with macromolecular complexes like lignin and cellulose, modulate the plant cell wall material. To date, feruloyl esterases prove to be the key in the enzymatic synthesis of phenolic sugar esters (Moreira et al., 2011, Vafiadi et al., 2006, Wong, 2006). FAEs act in synergy with main-chain-degrading enzymes, such as $\beta-(1,4)$-endoxylanases, to increase the release of ferulic acid from plant cell wall 
(Levasseur et al., 2006). FAEs release hemicellulose from lignin and also render free polysaccharide product, which is more amenable to degradation by other biocatalysts, such as endo- $\beta-1,4-x y l a n a s e s$ and $\alpha$-arabinofuranosidases (Prates et al., 2001). FAEs also enhances the release of glucose, so a higher release of glucose was obtained when cellulase, xylanase, and feruloyl esterase were used in the enzyme mixture to hydrolyze wheat straw for bioethanol production (Tabka et al., 2006).

Feruloyl esterases occur either as a non-modular enzyme (Crepin et al., 2003), but they also can be part of multimodular protein structures, as cellulosomes (Prates et al., 2001, Blum et al., 2000). Moreover, some FAEs contains cellulose binding modules (CBMs) (Kroon et al., 2000). The increase of the catalytic efficiency of FAEs has been reached by the fusion of CBM in a chimeric enzyme composed of FAE and endo-xylanase (Levasseur et al., 2005). The carbon source has an important effect on the enzymes produced during microorganism cultivation. In this way, several carbon sources were evaluated for FAE production, with wheat bran observed as the best inducer for FAE, and the washing of wheat bran favoring the enzymatic production (Braga et al., 2014).

Feruloyl esterases have been shown to be important enzymes in sugarcane bagasse degradation. The supplementation of an enzymatic commercial preparation with crude extract from $A$. oryzae containing ferulic acid esterase increased by $36 \%$ the conversion of cellulose in pretreated sugarcane bagasse (Braga et al., 2014). Moreover, a synergistic effect was observed in saccharification of steam pretreated sugarcane bagasse by a mixture of crude extracts from $T$. reesei and $A$. awamori, the latter a promising producer of ferulic acid esterase (Gottschalk et al., 2010). A mixture of cellulases and xylanases were supplemented with feruloyl esterases AnFaeA 
from A. niger, TsFaeC from Talaromyces stipitatus and NcFaed from $N$. crassa, to compare their potential to enhance total solubilization of sugarcane bagasse. Only the type C feruloyl esterase (TsFaeC) was able to release p-coumaric acid (pCA) from the natural substrate. However no increment in the release of glucose was observed, which could also indicate that, despite phenolic acid substitution, TrCel7B and TmXyn10A were capable of fragmenting xylans that may limit access to cellulose microfibrils. A moderate improvement in xylose release could be observed, especially by TsFaed, which indicates that solubilization of hydroxycinnamoyl groups from xylan or xylooligosaccharides enhanced saccharification of xylan to xylose monomers. The effect of feruloyl esterases was less clear. The three feruloyl esterases, types A, C, and D, had distinct product profiles on non-pretreated sugarcane bagasse substrate, indicating that bagasse could function as a possible natural substrate for FAE activity measurements (Varnai et al., 2014).

\subsubsection{Classification of FAEs}

Feruloyl esterases are currently classified as carbohydrate esterases (CE) in the family 1, based on their amino acid sequence (Henrissat, 1991, CAZy, 2015). A more elaborate classification uses multiple alignments of sequences or domains. The outcome of this genetic comparison has supported substrate specificity data and allowed feruloyl esterases to be sub-classified into four types (A-D), based on similarities in esterase activity profiles against synthetic methyl esters. The intra- and inter-group protein sequence identities of the enzymes indicates an evolutionary relationship between feruloyl esterases, acetyl xylan esterases and certain lipases (Crepin et al., 2004, Wong, 
2006). Each feruloyl esterase has its own specificity with regard to the release of specific cinnamic acids (Benoit et al., 2006).

Type A feruloyl esterases tend to be induced during growth on cereal-derived substrates and show a preference for the phenolic moiety of the substrate that contains methoxy substitutions, especially at carbon(s) 3 and/or 5, as occurs in ferulic and sinapic acids (Crepin et al., 2004). These FAEs have sequences related to those of lipases and are able to hydrolyze synthetic ferulate dehydrodimers. Examples of this group of enzymes include A. niger FAE-A (AnFaeA) (Wong, 2006). Type B feruloyl esterases are preferentially secreted during growth on sugar beet pulp and release ferulic acid esterlinked to either C-2 of feruloylated arabinose or C-6 of feruloylated galactose residues (Kroon and Williamson, 1996) but they are unable to release the dimeric forms of ferulate. The type B feruloyl esterases show a preference for the phenolic moiety of the substrate that contains one or two hydroxyl substitutions, as found in p-coumaric and caffeic acids, respectively (Crepin et al., 2004). These enzymes show sequence similarities to carboxylic esterase family 1 - acetyl xylan esterase. P. funiculosum FAE-B (Wong, 2006) and $N$. crassa FAE-I belong to this group (Crepin et al., 2003). Regarding specificity against synthetic substrates, both types of feruloyl esterases are active against methyl ferulate and methyl p-coumarate. Only type $A$ is active against methyl sinapate and only type $B$ is active against methyl caffeate. Type A feruloyl esterase appears to prefer hydrophobic substrates with bulky substituents on the benzene ring (Crepin et al., 2004, Wong, 2006). A third and fourth type of feruloyl esterase with broad specificity against synthetic hydroxycinnamic acids were reported, denominated types $C$ and D. They both hydrolyze the four methyl esters of 
hydroxycinnamic acids which are generally used as model substrates (methyl ferulate, methyl sinapinate, and methyl pcoumarate and methyl caffeate) but not diferulic compounds (Benoit et al., 2006, Wong, 2006). Type D feruloyl esterases are able to hydrolyze dimers. Type $C$ and $D$ show sequence similarities to chlorogenate esterase and xylanase, respectively. Type C includes A. niger FAE-B (AnFaeB) and Talaromyces stipitatus FAE-C. Type D enzymes include Piromyces equi EstA and Celluvibrio japonicus esterase D (Wong, 2006).

\subsubsection{Catalytic Mechanism of FAEs}

FAEs possess a common characteristic feature of the SerHis-Asp catalytic triad mechanism. Some variations in amino acid sequences forming surface loops and additional domains allow them to accommodate different aromatic substrates. In this case, serine acts as nucleophile, histidine as the general acid-base, and the aspartic acid helps to orient the histidine residue and further neutralize the charge that forms on histidine during the catalytic process. Therefore, the protonation states or the net charge of aspartic acid and histidine residues are very important for maintaining the activity of FAEs (Udatha et al., 2012, Ekici et al., 2008).

The crystal structures of FAEs from $A$. niger show that these enzymes have a common $\alpha / \beta$ hydrolase fold and a catalytic triad Ser-His-Asp also common in lipases (Hermoso et al., 2004, McAuley et al., 2004, Faulds et al., 2005). A ferulate esterase domain, component of a multimodular xylanase, called Xyn10B from $C$. thermocellum, also displays the $\alpha / \beta$ hydrolase fold and a catalytic triad Ser-His-Asp (Prates et al., 2001). The same catalytic triad was observed for a FAE from A. oryzae (Zeng et al., 2014). 


\subsection{Arabinofuranosidase}

As mentioned before, arabinoxylan is the most abundant hemicellulose in annual plants such as sugarcane bagasse, with a backbone of $\beta-(1,4)$ linked xylosyl residues substituted with arabinose ( $\mathrm{Xu}$ et al., 2005) . The $\alpha$-L-arabinofuranose ( $\alpha$-LAraf) residues are part of many plant cell wall polyssacharides, including arabinoxylan, arabinogalactan and arabinan (Kim, 2008) . $\alpha$-L-Arabinofuranosidases ( $\alpha$-L-AFases, EC 3.2.1.55) are accessory enzymes that cleave a-Larabinofuranosidic linkages at the nonreducing ends of arabinose-containing polysaccharides and play an integral role in the biodegradation of hemicellulose (Saha, 2000). They catalyze the hydrolysis of terminal $\alpha-\mathrm{L}-1,2-, \alpha-\mathrm{L}-1,3-$ and $\alpha-$ L-1,5-arabinofuranosyl residues, but also residues from pectic and hemicellulosic polysaccharides (branched arabinans,

debranched

(arabinogalactans,

$$
\text { arabinans), }
$$

arabinoxylans, heteropolysaccharides arabinoxyloglucans, glucuronoarabiloxylans, etc.) and different glycoconjugates. They act synergistically with other hemicellulases and pectic enzymes for the complete hydrolysis of hemicelluloses and pectins (Rye and Withers, 2000, Shallom et al., 2002, Saha, 2000, Shofiqur Rahman et al., 2003, Moreira et al., 2011). $\alpha-$ L-AFases accelerate the hydrolysis of the glycosidic bonds by more than $10^{7}$ fold, making them one of the most efficient catalysts known (Shallom et al., 2002).

A broad range of $\alpha-L-A F a s e s$ have been purified, and great diversity in the physicochemical properties, like pH, temperature, thermostability, molecular mass, etc., was noted among the enzymes from plant, fungal and bacterial sources. Microbial $\alpha-L-A F a s e s$ exhibit a diversity of $\mathrm{pH}$ and temperature activities, and present monomeric or dimeric form

(Revised by Saha, 2000). Arabinose, a competitive inhibitor ( $\left.\mathrm{K}_{i} 16.4 \mathrm{mM}\right)$ 
of Ara II, purified from $P$. capsulatum, had no effect on Ara I (purified from the same fungus) activity at concentrations of up to 40 mM (Filho et al., 1996). Arabinose also acted as a non-competitive inhibitor with $\mathrm{K}_{\mathrm{i}}$ of $38.4 \mathrm{mM}$ over a arabonifuranosidase (Abfa) from Aureobasidium pullulans (De Wet et al., 2008). Moreover, a-L-AFases possessing $\beta-$ xylosidase activity or xylanases with $\alpha$-L-arabinofuranosidase activity have also been described (Mai et al., 2000, Tateishi et al., 2014, De Wet et al., 2008).

$\alpha-L-A F a s e$ have been classified into seven different GH families, namely GH2, GH3, GH43, GH51, GH54, GH62 and GH93 (CAZy, 2015, Henrissat and Bairoch, 1993).

As well as feruloyl esterases, $\alpha$-arabinofuranosidases are essential enzymes to the complete deconstruction of sugarcane bagasse. The addition of $\alpha-L$-Araf and pectinase to a cellulase cocktail from $T$. harzianum was responsible for an increase of $116 \%$ in the total reducing sugar released during pretreated sugarcane bagasse hydrolysis (Delabona et al., 2013). A synergistic effect of a xylanase (XynC) and an $\alpha-$ arabinofuranosidase (AbfB) was observed in the production of xylooligossaccharides after hydrolysis of pretreated sugarcane bagasse. These results suggest that the synergistic improvement of xylooligosaccharides production is correlated by the action of $\mathrm{AbfB}$ on xylooligosaccharides having an arabinofuranose residue (Gonçalves et al., 2012). The efficiency of recombinant $\alpha$-arabinofuranosidases, endoxylanases and $\beta$-xylosidases for sugargane hydrolysis in several combinations of these enzymes were also evaluated, and it was found that synergic action of $\alpha$-arabinofuranosidases and endo-xylanases (heterosynergism) led to the production of higher amounts of xylose liberated from xylan backbone. This indicates the importance of the action of removal of lateral 
arabinofuranosyl residues in order to allow access of endoxylanase to xylose main chain (Goldbeck et al., 2014).

\subsubsection{Catalytic Mechanism of AFses}

Arabinofuranosidases belonging to GH43 and GH62 families possess conserved catalytic residues Asp-Asp-Glu. An $\alpha-$ arabinofuranosidase, ScAraf62A from Streptomyces coelicolor has the catalytic triad $\mathrm{Asp}^{202}-\mathrm{Asp}^{309}-\mathrm{Glu}^{361}$, and no enzyme activities was observed for the mutants $\mathrm{Asp}^{202}$ and $\mathrm{Glu}^{361}$ (Maehara et al., 2014). It was predicted that Asp and Glu behave as general base and acid catalytic residues, respectively (Shallom et al., 2005).

It was predicted that an $\alpha-L-A F a s e$ belonging to the GH 51 family, isolated from Geobacillus stearothermophilus T-6 hydrolyzes glicosidic bonds using a two-step doubledisplacement mechanism (the retaining mechanism). In the first step of the reaction (glycosylation), the acid-base residues act as a general acid, by protonation of the glycosidic oxygen and stabilizing the leaving group. In turn, the nucleophilic residue attacks the anomeric center of the scissile bond, forming a covalent glycosil-enzyme intermediate. In the second step (deglycosylation), the acid-base residue, this time acting as a general base, activates a water molecule that attacks the anomeric center of the glycosyl-enzyme intermediate, liberating the free sugar with an overall retention of the anomeric configuration. Both steps involve the formation of an oxicarbaniom ion-like transition state (Shallom et al., 2002).

\section{Conclusion and Perspectives}


Bagasse is an important residue generated during sugarcane processing, and its accumulation is a source of many environmental problems due to pollution caused by its accumulation. Its utilization as feedstock for second generation bioethanol production needs efficient enzyme cocktails containing accessory enzymes in addition to endo and exo cleaving enzymes. The use of lignocellulosic feedstock is an environmentally friendly way out, since it reduces the environmental problem caused by accumulation of this residue, reduces dependence on fossil fuels and still adds value to a waste.

The synergic contribution of ferulic acid esterases and arabinofuranosidades in the total deconstruction of bagasse are of great importance, since this can allow the use of reduced protein loads, and so reach efficient biomass hydrolysis with low costs, but commercial enzyme preparations usually lack at least one of these two important accessory enzymes (Braga et al., 2014, Gottschalk et al., 2010).

Filamentous fungi are promising organisms for the production of broad spectrum hydrolytic enzymes. Characterization of the transcriptome of diverse lignocellulolytic fungi is an important approach for the identification of novel genes involved in the regulation and expression of these enzymes. Increased knowledge of genes and regulatory pathways present in such fungi that are involved in the degradation of organic residues such as bagasse will contribute to the second generation bioethanol industry through the identification and development of improved strains capable of hydrolyzing plant biomass to simple fermentable sugars. Increased enzymatic efficiencies and improved hydrolytic enzyme cocktail development will contribute to reducing cellulosic bioethanol production costs, given that a 
main bottleneck in the production process is the recalcitrance of the plant cell wall.

\section{Acknowledgements}

The authors acknowledge the receipt financial support from the Brazilian Research Council (CNPq), Coordination for the Improvement of Higher Level Personnel (CAPES), Foundation for Research Support of Federal District (FAPDF) and the National Institute for Science and Technology of Bioethanol.

\section{References}

ANDREAUS, J., FILHO, E. X. F. \& BON, E. P. D. S. 2008. Biotechnology of HolocelluloseDegrading Enzymes. In: HOU, C. T. \& SHAW, J. (eds.) Biocatalysis and Bioenergy. John Wiley \& Sons, Inc.

ASPGD. 2015. Aspergillus Genoma Database [Online]. [Accessed 03/23/2015 2015].

BATTAGLIA, E., BENOIT, I., VAN DEN BRINK, J., WIEBENGA, A., COUTINHO, P. M., HENRISSAT, B. \& DE VRIES, R. P. 2011. Carbohydrate-active enzymes from the zygomycete fungus Rhizopus oryzae: a highly specialized approach to carbohydrate degradation depicted at genome level. BMC genomics, 12, 38.

BENOIT, I., NAVARRO, D., MARNET, N., RAKOTOMANOMANA, N., LESAGE-MEESSEN, L., SIGOILLOT, J.-C., ASTHER, M. \& ASTHER, M. 2006. Feruloyl esterases as a tool for the release of phenolic compounds from agro-industrial by-products. Carbohydrate Research, 341, 1820-1827.

BERKA, R. M., GRIGORIEV, I. V., OTILLAR, R., SALAMOV, A., GRIMWOOD, J., REID, I., ISHMAEL, N., JOHN, T., DARMOND, C. \& MOISAN, M.-C. 2011. Comparative genomic analysis of the thermophilic biomass-degrading fungi Myceliophthora thermophila and Thielavia terrestris. Nature Biotechnology, 29, 922-927.

BEUKES, N., CHAN, H., DOI, R. H. \& PLETSCHKE, B. I. 2008. Synergistic associations between Clostridium cellulovorans enzymes XynA, ManA and EngE against sugarcane bagasse. Enzyme and Microbial Technology, 42, 492-498.

BLUM, D. L., KATAEVA, I. A., LI, X.-L. \& LUNGDAHL, L. G. 2000. Feruloyl Esterase Activity of the Clostridium thermocellum Cellulosome Can Be Attributed to Previously Unknown Domains of XynY and XynZ. Journal of Bacteriology, 182, 1346-1351.

BRAGA, C. M. P., DA SILVA DELABONA, P., DA SILVA LIMA, D. J., PAIXÃO, D. A. A., DA CRUZ PRADELLA, J. G. \& FARINAS, C. S. 2014. Addition of feruloyl esterase and xylanase produced on-site improves sugarcane bagasse hydrolysis. Bioresource Technology, 170, 316-324.

BRIENZO, M., FERREIRA, S., VICENTIM, M. P., DE SOUZA, W. \& SANT'ANNA, C. 2014. Comparison Study on the Biomass Recalcitrance of Different Tissue Fractions of Sugarcane Culm. BioEnergy Research, 7, 1454-1465.

BROAD-INSTITUTE. 2015. Broad Institute [Online]. [Accessed 03/23/2015 2015]. 
CASTRO, L. D. S., ANTONIÊTO, A. C. C., PEDERSOLI, W. R., SILVA-ROCHA, R., PERSINOTI, G. F. \& SILVA, R. N. 2014. Expression pattern of cellulolytic and xylanolytic genes regulated by transcriptional factors XYR1 and CRE1 are affected by carbon source in Trichoderma reesei. Gene Expression Patterns, 14, 88-95.

CAZY. 2015. Carbohydrate-Active Enzyme database [Online]. Available: http://www.cazy.org/. [Accessed 01/15/2015.

CERQUEIRA LEITE, R. C., LEAL, M. R. L. V., CORTEZ, L. A. B., GRIFFIN, W. M. \& SCANDIFFIO, M. I. G. 2009. Can Brazil replace $5 \%$ of the 2025 gasoline world demand with ethanol? Energy, 34, 655-661.

CHAMBERGO, F. S., BONACCORSI, E. D., FERREIRA, A. J. S., RAMOS, A. S. P., FERREIRA , J. R., ABRAHÃO-NETO, J., FARAH, J. P. S. \& EL-DORRY, H. 2002. Elucidation of the Metabolic Fate of Glucose in the Filamentous Fungus Trichoderma reesei Using Expressed Sequence Tag (EST) Analysis and cDNA Microarrays. Journal of Biological Chemistry, 277, 13983-13988.

CHANDEL, A., ANTUNES, F., SILVA, M. \& DA SILVA, S. 2013. Unraveling the structure of sugarcane bagasse after soaking in concentrated aqueous ammonia (SCAA) and ethanol production by Scheffersomyces (Pichia) stipitis. Biotechnology for Biofuels, 6, 102.

CHANDEL, A. K., DA SILVA, S. S., CARVALHO, W. \& SINGH, O. V. 2012. Sugarcane bagasse and leaves: foreseeable biomass of biofuel and bioproducts. Journal of Chemical Technology and Biotechnology, 87, 11-20.

CORADETTI, S. T., CRAIG, J. P., XIONG, Y., SHOCK, T., TIAN, C. \& GLASS, N. L. 2012. Conserved and essential transcription factors for cellulase gene expression in ascomycete fungi. Proceedings of the National Academy of Sciences, 109, 7397-7402.

COUGHLAN, M. P., TUOHY, M. G., FILHO, E. X. F., PULS, J., CLAEYSSENS, M., VRSANSKA, M. \& HUGHES, M. M. 1993. Enzymological aspects of microbial hemicellulases with emphasis on fungal systems. In: COUGHLAN, M. P. \& HAZLEWOOD, G. P. (eds.) Hemicellulose and Hemicellulases. Cambridge, Great Britain: Portaland Press Research Monograph IV.

COUTURIER, M., NAVARRO, D., OlivÉ, C., CHEVRET, D., HAON, M., FAVEL, A., LeSAGEMEESSEN, L., HENRISSAT, B., COUTINHO, P. M. \& BERRIN, J.-G. 2012. Post-genomic analyses of fungal lignocellulosic biomass degradation reveal the unexpected potential of the plant pathogen Ustilago maydis. BMC genomics, 13, 57.

CREPIN, V. F., FAULDS, C. B. \& CONNERTON, I. F. 2003. A non-modular type B feruloyl esterase from Neurospora crassa exhibits concentration-dependent substrate inhibition. Biochemical Journal, 370, 417-427.

CREPIN, V. F., FAULDS, C. B. \& CONNERTON, I. F. 2004. Functional classification of the microbial feruloyl esterases. Applied Microbiology and Biotechnology, 63, 647-652.

DE VRIES, R. P., VANKUYK, P. A., KESTER, H. C. M. \& VISSER, J. 2002. The Aspergillus niger faeB gene encodes a second feruloyl esterase involved in pectin and xylan degradation and is specifically induced in the presence of aromatic compounds. Biochemical Journal, 363, 377-386.

DE WET, B. J., MATTHEW, M. K., STORBECK, K.-H., VAN ZYL, W. H. \& PRIOR, B. A. 2008. Characterization of a family $54 \alpha$-L-arabinofuranosidase from Aureobasidium pullulans. Applied Microbiology and Biotechnology, 77, 975-983. 
DELABONA, P. D. S., COTA, J., HOFFMAM, Z. B., PAIXÃO, D. A. A., FARINAS, C. S., CAIRO, J. P. L. F., LIMA, D. J., SQUINA, F. M., RULLER, R. \& PRADELLA, J. G. D. C. 2013. Understanding the cellulolytic system of Trichoderma harzianum P49P11 and enhancing saccharification of pretreated sugarcane bagasse by supplementation with pectinase and $\alpha-I$-arabinofuranosidase. Bioresource Technology, 131, 500-507.

DELMAS, S., PULLAN, S. T., GADDIPATI, S., KOKOLSKI, M., MALLA, S., BLYTHE, M. J., IBBETT, R., CAMPBELL, M., LIDDELL, S. \& ABOOBAKER, A. 2012. Uncovering the genome-wide transcriptional responses of the filamentous fungus Aspergillus niger to lignocellulose using RNA sequencing. PLoS genetics, 8, e1002875.

EKICI, Ö. D., PAETZEL, M. \& DALBEY, R. E. 2008. Unconventional serine proteases: Variations on the catalytic Ser/His/Asp triad configuration. Protein Science : A Publication of the Protein Society, 17, 2023-2037.

ENSINAS, A. V., NEBRA, S. A., LOZANO, M. A. \& SERRA, L. M. 2007. Analysis of process steam demand reduction and electricity generation in sugar and ethanol production from sugarcane. Energy Conversion and Management, 48, 2978-2987.

FAULDS, C. B., MOLINA, R., GONZALEZ, R., HUSBAND, F., JUGE, N., SANZ-APARICIO, J. \& HERMOSO, J. A. 2005. Probing the determinants of substrate specificity of a feruloyl esterase, AnFaeA, from Aspergillus niger. FEBS Journal, 272, 4362-4371.

FILHO, E. X., PULS, J. \& COUGHLAN, M. P. 1996. Purification and characterization of two arabinofuranosidases from solid-state cultures of the fungus Penicillium capsulatum. Appl Environ Microbiol, 62, 168-173.

FOREMAN, P. K., BROWN, D., DANKMEYER, L., DEAN, R., DIENER, S., DUNN-COLEMAN, N. S., GOEDEGEBUUR, F., HOUFEK, T. D., ENGLAND, G. J. \& KELLEY, A. S. 2003. Transcriptional regulation of biomass-degrading enzymes in the filamentous fungus Trichoderma reesei. Journal of Biological Chemistry, 278, 31988-31997.

GALAGAN, J. E., CALVO, S. E., CUOMO, C., MA, L.-J., WORTMAN, J. R., BATZOGLOU, S., LEE, S.-I., BASTURKMEN, M., SPEVAK, C. C., CLUTTERBUCK, J., KAPITONOV, V., JURKA, J., SCAZZOCCHIO, C., FARMAN, M., BUTLER, J., PURCELL, S., HARRIS, S., BRAUS, G. H., DRAHT, O., BUSCH, S., D'ENFERT, C., BOUCHIER, C., GOLDMAN, G. H., BELLPEDERSEN, D., GRIFFITHS-JONES, S., DOONAN, J. H., YU, J., VIENKEN, K., PAIN, A., FREITAG, M., SELKER, E. U., ARCHER, D. B., PENALVA, M. A., OAKLEY, B. R., MOMANY, M., TANAKA, T., KUMAGAI, T., ASAI, K., MACHIDA, M., NIERMAN, W. C., DENNING, D. W., CADDICK, M., HYNES, M., PAOLETTI, M., FISCHER, R., MILLER, B., DYER, P., SACHS, M. S., OSMANI, S. A. \& BIRREN, B. W. 2005. Sequencing of Aspergillus nidulans and comparative analysis with A. fumigatus and A. oryzae. Nature, 438, 1105-1115.

GARBER, M., GRABHERR, M. G., GUTTMAN, M. \& TRAPNELL, C. 2011. Computational methods for transcriptome annotation and quantification using RNA-seq. Nature methods, 8, 469-477.

GIBBONS, J. G. \& ROKAS, A. 2013. The function and evolution of the Aspergillus genome. Trends in microbiology, 21, 14-22.

GOFFEAU, A., BARRELL, B., BUSSEY, H., DAVIS, R., DUJON, B., FELDMANN, H., GALIBERT, F., HOHEISEL, J., JACQ, C. \& JOHNSTON, M. 1996. Life with 6000 genes. Science, 274, 546-567.

GOLDBECK, R., DAMÁSIO, A. R., GONÇALVES, T. A., MACHADO, C. B., PAIXÃO, D. A., WOLF, L. D., MANDELLI, F., ROCHA, G. J., RULLER, R. \& SQUINA, F. M. 2014. Development of hemicellulolytic enzyme mixtures for plant biomass deconstruction on target 
biotechnological applications. Applied Microbiology and Biotechnology, 98, 85138525.

GOLDEMBERG, J. 2007. Ethanol for a Sustainable Energy Future. Science, 315, 808-810.

GONÇALVES, T. A., DAMÁSIO, A. R. L., SEGATO, F., ALVAREZ, T. M., BRAGATTO, J., BRENELLI, L. B., CITADINI, A. P. S., MURAKAMI, M. T., RULLER, R., PAES LEME, A. F., PRADE, R. A. \& SQUINA, F. M. 2012. Functional characterization and synergic action of fungal xylanase and arabinofuranosidase for production of xylooligosaccharides. Bioresource Technology, 119, 293-299.

GOTTSCHALK, L. M. F., OLIVEIRA, R. A. \& DA SILVA BON, E. P. 2010. Cellulases, xylanases, $\beta-$ glucosidase and ferulic acid esterase produced by Trichoderma and Aspergillus act synergistically in the hydrolysis of sugarcane bagasse. Biochemical Engineering Journal, 51, 72-78.

HÄKKINEN, M., ARVAS, M., OJA, M., ARO, N., PENTTILÄ, M., SALOHEIMO, M. \& PAKULA, T. M. 2012. Re-annotation of the CAZy genes of Trichoderma reesei and transcription in the presence of lignocellulosic substrates. Microb Cell Fact, 11, 134.

HENRISSAT, B. 1991. A classification of glycosyl hydrolases based on amino acid sequence similarities. Biochem J, 280, 309 - 316.

HENRISSAT, B. \& BAIROCH, A. 1993. New families in the classification of glycosyl hydrolases based on amino acid sequence similarities. Biochemical Journal, 293, 781-788.

HERMOSO, J. A., SANZ-APARICIO, J., MOLINA, R., JUGE, N., GONZÁLEZ, R. \& FAULDS, C. B. 2004. The Crystal Structure of Feruloyl Esterase A from Aspergillus niger Suggests Evolutive Functional Convergence in Feruloyl Esterase Family. Journal of Molecular Biology, 338, 495-506.

HORTA, M. A. C., VICENTINI, R., DA SILVA DELABONA, P., LABORDA, P., CRUCELLO, A., FREITAS, S., KUROSHU, R. M., POLIKARPOV, I., DA CRUZ PRADELLA, J. G. \& SOUZA, A. P. 2014. Transcriptome profile of Trichoderma harzianum IOC-3844 induced by sugarcane bagasse. PLoS One, 9, e88689.

JACOBSEN, S. E. \& WYMAN, C. E. 2002. Xylose monomer and oligomer yields for uncatalyzed hydrolysis of sugarcane bagasse hemicellulose at varying solids concentration. Industrial \& Engineering Chemistry Research, 41, 1454-1461.

KHALDI, N. \& WOLFE, K. H. 2008. Elusive Origins of the Extra Genes in Aspergillus oryzae. PLoS One, 3, e3036.

KIM, T. J. 2008. Microbial exo-and endo-arabinosyl hydrolases: structure, function, and application in L-arabinose production. Carbohydrate-Active Enzymes, 229-257.

KROON, P. A. \& WILLIAMSON, G. 1996. Purification and characterization of a novel esterase induced by growth of Aspergillus niger on sugar beet pulp. Biotechnol Appl Biochem, 23, 255-262.

KROON, P. A., WILLIAMSON, G., FISH, N. M., ARCHER, D. B. \& BELSHAW, N. J. 2000. A modular esterase from Penicillium funiculosum which releases ferulic acid from plant cell walls and binds crystalline cellulose contains a carbohydrate binding module. European Journal of Biochemistry, 267, 6740-6752.

KUBICEK, C. P., HERRERA-ESTRELLA, A., SEIDL-SEIBOTH, V., MARTINEZ, D. A., DRUZHININA, I. S., THON, M., ZEILINGER, S., CASAS-FLORES, S., HORWITZ, B. A. \& MUKHERJEE, P. K. 2011. Comparative genome sequence analysis underscores mycoparasitism as the ancestral life style of Trichoderma. Genome biology, 12, R40. 
LAVARACK, B. P., GRIFFIN, G. J. \& RODMAN, D. 2002. The acid hydrolysis of sugarcane bagasse hemicellulose to produce xylose, arabinose, glucose and other products. Biomass and Bioenergy, 23, 367-380.

LEVASSEUR, A., NAVARRO, D., PUNT, P. J., BELAÏCH, J.-P., ASTHER, M. \& RECORD, E. 2005. Construction of Engineered Bifunctional Enzymes and Their Overproduction in Aspergillus niger for Improved Enzymatic Tools To Degrade Agricultural By-Products. Appl Environ Microbiol, 71, 8132-8140.

LEVASSEUR, A., SALOHEIMO, M., NAVARRO, D., ANDBERG, M., MONOT, F., NAKARI-SETALA, T., ASTHER, M. \& RECORD, E. 2006. Production of a chimeric enzyme tool associating the Trichoderma reesei swollenin with the Aspergillus niger feruloyl esterase A for release of ferulic acid. Appl Microbiol Biotechnol, 73, 872 - 880.

LUBERTOZZI, D. \& KEASLING, J. D. 2009. Developing Aspergillus as a host for heterologous expression. Biotechnology Advances, 27, 53-75.

MACDONALD, J., DOERING, M., CANAM, T., GONG, Y., GUTTMAN, D., CAMPBELL, M. \& MASTER, E. 2011. Transcriptomic responses of the softwood-degrading white-rot fungus Phanerochaete carnosa during growth on coniferous and deciduous wood. Appl Environ Microbiol, 77, 3211 - 3218.

MACEDO, I., SEABRA, J. \& DA SILVA, J. 2008. Greenhouse gases emissions in the production and use of ethanol from sugarcane in Brazil: The 2005/2006 averages and a prediction for 2020. Biomass and Bioenergy.

MACHIDA, M., ASAI, K., SANO, M., TANAKA, T., KUMAGAI, T., TERAI, G., KUSUMOTO, K.-I., ARIMA, T., AKITA, O. \& KASHIWAGI, Y. 2005. Genome sequencing and analysis of Aspergillus oryzae. Nature, 438, 1157-1161.

MACKENZIE, C. R. \& BILOUS, D. 1988. Ferulic Acid Esterase Activity from Schizophyllum commune. Appl Environ Microbiol, 54, 1170-1173.

MAEDA, H., SANO, M., MARUYAMA, Y., TANNO, T., AKAO, T., TOTSUKA, Y., ENDO, M., SAKURADA, R., YAMAGATA, Y., MACHIDA, M., AKITA, O., HASEGAWA, F., ABE, K., GOMI, K., NAKAJIMA, T. \& IGUCHI, Y. 2004. Transcriptional analysis of genes for energy catabolism and hydrolytic enzymes in the filamentous fungus Aspergillus oryzae using cDNA microarrays and expressed sequence tags. Applied Microbiology and Biotechnology, 65, 74-83.

MAEHARA, T., FUJIMOTO, Z., ICHINOSE, H., MICHIKAWA, M., HARAZONO, K. \& KANEKO, S. 2014. Crystal Structure and Characterization of the Glycoside Hydrolase Family $62 \alpha-$ I-Arabinofuranosidase from Streptomyces coelicolor. Journal of Biological Chemistry, 289, 7962-7972.

MAI, V., WIEGEL, J. \& LORENZ, W. W. 2000. Cloning, sequencing, and characterization of the bifunctional xylosidase-arabinosidase from the anaerobic thermophile Thermoanaerobacter ethanolicus. Gene, 247, 137-143.

MALLET, L. V., BECQ, J. \& DESCHAVANNE, P. 2010. Whole genome evaluation of horizontal transfers in the pathogenic fungus Aspergillus fumigatus. BMC genomics, 11, 171.

MARDIS, E. R. 2008. The impact of next-generation sequencing technology on genetics. Trends in genetics, 24, 133-141.

MARTINEZ, D., BERKA, R. M., HENRISSAT, B., SALOHEIMO, M., ARVAS, M., BAKER, S. E., CHAPMAN, J., CHERTKOV, O., COUTINHO, P. M., CULLEN, D., DANCHIN, E. G. J., GRIGORIEV, I. V., HARRIS, P., JACKSON, M., KUBICEK, C. P., HAN, C. S., HO, I., LARRONDO, L. F., DE LEON, A. L., MAGNUSON, J. K., MERINO, S., MISRA, M., NELSON, 
B., PUTNAM, N., ROBBERTSE, B., SALAMOV, A. A., SCHMOLL, M., TERRY, A., THAYER, N., WESTERHOLM-PARVINEN, A., SCHOCH, C. L., YAO, J., BARABOTE, R., NELSON, M. A., DETTER, C., BRUCE, D., KUSKE, C. R., XIE, G., RICHARDSON, P., ROKHSAR, D. S., LUCAS, S. M., RUBIN, E. M., DUNN-COLEMAN, N., WARD, M. \& BRETTIN, T. S. 2008. Genome sequencing and analysis of the biomass-degrading fungus Trichoderma reesei (syn. Hypocrea jecorina). Nat Biotech, 26, 553-560.

MCAULEY, K. E., SVENDSEN, A., PATKAR, S. A. \& WILSON, K. S. 2004. Structure of a feruloyl esterase from Aspergillus niger. Acta Crystallographica Section D, 60, 878-887.

MOREIRA, L. R. S., FERREIRA, G. V., SANTOS, S. S. T., RIBEIRO, A. P. S., SIQUEIRA, F. G. \& FERREIRA FILHO, E. X. 2012. The hydrolysis of agro-industrial residues by holocellulose-degrading enzymes. Brazilian Journal of Microbiology, 43, 498-505.

MOREIRA, L. R. S., MILANEZI, N. V. G. \& FILHO, E. X. F. 2011. Enzymology of Plant Cell Wall Breakdown: An Update. In: BUCKERIDGE, M. S. \& GOLDMAN, G. H. (eds.) Routes to Cellulosic Ethanol. Springer New York.

NCBI. 2015. National Center for Biotechnology Information - Genome [Online]. [Accessed 03/23/2015 2015].

NIERMAN, W. C., PAIN, A., ANDERSON, M. J., WORTMAN, J. R., KIM, H. S., ARROYO, J., BERRIMAN, M., ABE, K., ARCHER, D. B., BERMEJO, C., BENNETT, J., BOWYER, P., CHEN, D., COLLINS, M., COULSEN, R., DAVIES, R., DYER, P. S., FARMAN, M., FEDOROVA, N., FEDOROVA, N., FELDBLYUM, T. V., FISCHER, R., FOSKER, N., FRASER, A., GARCIA, J. L., GARCIA, M. J., GOBLE, A., GOLDMAN, G. H., GOMI, K., GRIFFITHJONES, S., GWILLIAM, R., HAAS, B., HAAS, H., HARRIS, D., HORIUCHI, H., HUANG, J., HUMPHRAY, S., JIMENEZ, J., KELLER, N., KHOURI, H., KITAMOTO, K., KOBAYASHI, T., KONZACK, S., KULKARNI, R., KUMAGAI, T., LAFTON, A., LATGE, J.-P., LI, W., LORD, A., LU, C., MAJOROS, W. H., MAY, G. S., MILLER, B. L., MOHAMOUD, Y., MOLINA, M., MONOD, M., MOUYNA, I., MULLIGAN, S., MURPHY, L., O'NEIL, S., PAULSEN, I., PENALVA, M. A., PERTEA, M., PRICE, C., PRITCHARD, B. L., QUAIL, M. A., RABBINOWITSCH, E., RAWLINS, N., RAJANDREAM, M.-A., REICHARD, U., RENAULD, H., ROBSON, G. D., DE CORDOBA, S. R., RODRIGUEZ-PENA, J. M., RONNING, C. M., RUTTER, S., SALZBERG, S. L., SANCHEZ, M., SANCHEZ-FERRERO, J. C., SAUNDERS, D., SEEGER, K., SQUARES, R., SQUARES, S., TAKEUCHI, M., TEKAIA, F., TURNER, G., DE ALDANA, C. R. V., WEIDMAN, J., WHITE, O., WOODWARD, J., YU, J.-H., FRASER, C., GALAGAN, J. E., ASAI, K., MACHIDA, M., HALL, N., BARRELL, B. \& DENNING, D. W. 2005. Genomic sequence of the pathogenic and allergenic filamentous fungus Aspergillus fumigatus. Nature, 438, 1151-1156.

PANDEY, A., SOCCOL, C. R., NIGAM, P. \& SOCCOL, V. T. 2000. Biotechnological potential of agro-industrial residues. I: sugarcane bagasse. Bioresource Technology, 74, 69-80.

PAYNE, G. A., NIERMAN, W. C., WORTMAN, J. R., PRITCHARD, B. L., BROWN, D., DEAN, R. A., BHATNAGAR, D., CLEVELAND, T. E., MACHIDA, M. \& YU, J. 2006. Whole genome comparison of Aspergillus flavus and A. oryzae. Medical Mycology, 44, 9-11.

PEL, H. J., DE WINDE, J. H., ARCHER, D. B., DYER, P. S., HOFMANN, G., SCHAAP, P. J., TURNER, G., DE VRIES, R. P., ALBANG, R. \& ALBERMANN, K. 2007. Genome sequencing and analysis of the versatile cell factory Aspergillus niger CBS 513.88. Nature Biotechnology, 25, 221-231. 
PENG, F., REN, J.-L., XU, F., BIAN, J., PENG, P. \& SUN, R.-C. 2009. Comparative Study of Hemicelluloses Obtained by Graded Ethanol Precipitation from Sugarcane Bagasse. Journal of Agricultural and Food Chemistry, 57, 6305-6317.

PORTNOY, T., MARGEOT, A., SEIDL-SEIBOTH, V., LE CROM, S., CHAABANE, F. B., LINKE, R., SEIBOTH, B. \& KUBICEK, C. P. 2011. Differential regulation of the cellulase transcription factors XYR1, ACE2, and ACE1 in Trichoderma reesei strains producing high and low levels of cellulase. Eukaryotic cell, 10, 262-271.

PRATES, J. A. M., TARBOURIECH, N., CHARNOCK, S. J., FONTES, C. M. G. A., FERREIRA, L. S. M. A. \& DAVIES, G. J. 2001. The Structure of the Feruloyl Esterase Module of Xylanase 10B from Clostridium thermocellum Provides Insights into Substrate Recognition. Structure, 9, 1183-1190.

RALPH, J., LUNDQUIST, K., BRUNOW, G., LU, F., KIM, H., SCHATZ, P., MARITA, J., HATFIELD, R., RALPH, S., CHRISTENSEN, J. \& BOERJAN, W. 2004. Lignins: Natural polymers from oxidative coupling of 4-hydroxyphenyl- propanoids. Phytochemistry Reviews, 3, 2960.

RIES, L., PULLAN, S. T., DELMAS, S., MALLA, S., BLYTHE, M. J. \& ARCHER, D. B. 2013. Genomewide transcriptional response of Trichoderma reesei to lignocellulose using RNA sequencing and comparison with Aspergillus niger. BMC genomics, 14, 541.

RYE, C. S. \& WITHERS, S. G. 2000. Glycosidase mechanisms. Curr Opin Chem Biol, 4, 573-580.

SAHA, B. C. 2000. $\alpha$-I-Arabinofuranosidases: biochemistry, molecular biology and application in biotechnology. Biotechnology Advances, 18, 403-423.

SEMOVA, N., STORMS, R., JOHN, T., GAUDET, P., ULYCZNYJ, P., MIN, X. J., SUN, J., BUTLER, G. \& TSANG, A. 2006. Generation, annotation, and analysis of an extensive Aspergillus niger EST collection. BMC microbiology, 6, 7.

SHALLOM, D., BELAKHOV, V., SOLOMON, D., GILEAD-GROPPER, S., BAASOV, T., SHOHAM, G. \& SHOHAM, Y. 2002. The identification of the acid-base catalyst of $\alpha$ arabinofuranosidase from Geobacillus stearothermophilus T-6, a family 51 glycoside hydrolase. FEBS Letters, 514, 163-167.

SHALLOM, D., LEON, M., BRAVMAN, T., BEN-DAVID, A., ZAIDE, G., BELAKHOV, V., SHOHAM, G., SCHOMBURG, D., BAASOV, T. \& SHOHAM, Y. 2005. Biochemical characterization and identification of the catalytic residues of a family $43 \beta$-D-xylosidase from Geobacillus stearothermophilus T-6. Biochemistry, 44, 387-397.

SHOFIQUR RAHMAN, A. K. M., KATO, K., KAWAI, S. \& TAKAMIZAWA, K. 2003. Substrate specificity of the $\alpha$-I-arabinofuranosidase from Rhizomucor pusillus HHT-1. Carbohydrate Research, 338, 1469-1476.

SIQUEIRA, F. G. \& FILHO, E. X. F. 2010. Plant Cell Wall as a substrate for the production of enzymes with industrial applications. Bentham Science Publishers, 7, 55-60.

SØRENSEN, A., TELLER, P. J., LÜBECK, P. S. \& AHRING, B. K. 2011. Onsite enzyme production during bioethanol production from biomass: screening for suitable fungal strains. Applied Biochemistry and Biotechnology, 164, 1058-1070.

SOUZA, A. P., LEITE, D. C., PATTATHIL, S., HAHN, M. G. \& BUCKERIDGE, M. S. 2013a. Composition and structure of sugarcane cell wall polysaccharides: implications for second-generation bioethanol production. BioEnergy Research, 6, 564-579.

SOUZA, W. R., DE GOUVEA, P. F., SAVOLDI, M., MALAVAZI, I., DE SOUZA BERNARDES, L. A., GOLDMAN, M. H. S., DE VRIES, R. P., DE CASTRO OLIVEIRA, J. V. \& GOLDMAN, G. H. 
2011. Transcriptome analysis of Aspergillus niger grown on sugarcane bagasse. Biotechnology for Biofuels, 4, 1-17.

SOUZA, W. R., MAITAN-ALFENAS, G. P., DE GOUVÊA, P. F., BROWN, N. A., SAVOLDI, M., BATTAGLIA, E., GOLDMAN, M. H. S., DE VRIES, R. P. \& GOLDMAN, G. H. 2013b. The influence of Aspergillus niger transcription factors $A r a R$ and $X \ln R$ in the gene expression during growth in $d$-xylose, l-arabinose and steam-exploded sugarcane bagasse. Fungal Genetics and Biology, 60, 29-45.

SRIVASTAVA, M., SHAHID, M., PANDEY, S., SINGH, A. \& KUMAR, V. 2014. Trichoderma Genome to Genomics: A Review. J Data Mining Genomics Proteomics, 5, 21530602.10001.

SUN, J.-X., SUN, R., SUN, X.-F. \& SU, Y. 2004a. Fractional and physico-chemical characterization of hemicelluloses from ultrasonic irradiated sugarcane bagasse. Carbohydrate Research, 339, 291-300.

SUN, J. X., SUN, X. F., SUN, R. C. \& SU, Y. Q. 2004b. Fractional extraction and structural characterization of sugarcane bagasse hemicelluloses. Carbohydrate Polymers, 56, 195-204.

SUN, X.-F., WANG, H., ZHANG, G., FOWLER, P. \& RAJARATNAM, M. 2011. Extraction and characterization of lignins from maize stem and sugarcane bagasse. Journal of Applied Polymer Science, 120, 3587-3595.

SZCZERBOWSKI, D., PITARELO, A. P., ZANDONÁ FILHO, A. \& RAMOS, L. P. 2014. Sugarcane biomass for biorefineries: Comparative composition of carbohydrate and noncarbohydrate components of bagasse and straw. Carbohydrate Polymers, 114, 95101.

TABKA, M. G., HERPOËL-GIMBERT, I., MONOD, F., ASTHER, M. \& SIGOILLOT, J. C. 2006. Enzymatic saccharification of wheat straw for bioethanol production by a combined cellulase xylanase and feruloyl esterase treatment. Enzyme and Microbial Technology, 39, 897-902.

TATEISHI, A., KAMIYOSHIHARA, Y., MATSUNO, J., MIYOHASHI, F., SHIBA, H., KANAYAMA, Y., WATANABE, K., NOMURA, K. \& INOUE, H. 2014. Heterologous expression of tomato glycoside hydrolase family $3 \alpha$-L-arabinofuranosidase/ $\beta$-xylosidases in tobacco suspension cultured cells and synergic action of a family 51 isozyme under antisense suppression of the enzyme. Physiologia Plantarum, 150, 238-251.

TOPAKAS, E., VAFIADI, C. \& CHRISTAKOPOULOS, P. 2007. Microbial production, characterization and applications of feruloyl esterases. Process Biochemistry, 42, 497509.

UDATHA, D. B. R. K. G., MAPELLI, V., PANAGIOTOU, G. \& OLSSON, L. 2012. Common and Distant Structural Characteristics of Feruloyl Esterase Families from Aspergillus oryzae. PLoS One, 7, e39473.

VAFIADI, C., TOPAKAS, E., CHRISTAKOPOULOS, P. \& FAULDS, C. B. 2006. The feruloyl esterase system of Talaromyces stipitatus: Determining the hydrolytic and synthetic specificity of TsFaeC. Journal of Biotechnology, 125, 210-221.

VAN DYK, J. S. \& PLETSCHKE, B. I. 2012. A review of lignocellulose bioconversion using enzymatic hydrolysis and synergistic cooperation between enzymes-Factors affecting enzymes, conversion and synergy. Biotechnology Advances, 30, 1458-1480.

VARNAI, A., COSTA, T., FAULDS, C., MILAGRES, A., SIIKA-AHO, M. \& FERRAZ, A. 2014. Effects of enzymatic removal of plant cell wall acylation (acetylation, $p$-coumaroylation, and 
feruloylation) on accessibility of cellulose and xylan in natural (non-pretreated) sugar cane fractions. Biotechnology for Biofuels, 7, 153.

WANG, T.-Y., CHEN, H.-L., LU, M., CHEN, Y.-C., SUNG, H.-M., MAO, C.-T., CHO, H.-Y., KE, H.M., HWA, T.-Y. \& RUAN, S.-K. 2011. Functional characterization of cellulases identified from the cow rumen fungus Neocallimastix patriciarum W5 by transcriptomic and secretomic analyses. Biotechnology for Biofuels, 4, 24.

WONG, D. S. 2006. Feruloyl esterase. Applied Biochemistry and Biotechnology, 133, 87-112.

XU, F., SUN, J. X., LIU, C. F. \& SUN, R. C. 2006. Comparative study of alkali- and acidic organic solvent-soluble hemicellulosic polysaccharides from sugarcane bagasse. Carbohydrate Research, 341, 253-261.

XU, F., SUN, R.-C., SUN, J.-X., LIU, C.-F., HE, B.-H. \& FAN, J.-S. 2005. Determination of cell wall ferulic and p-coumaric acids in sugarcane bagasse. Analytica Chimica Acta, 552, $207-$ 217.

ZENG, Y., YIN, X., WU, M.-C., YU, T., FENG, F., ZHU, T.-D. \& PANG, Q.-F. 2014. Expression of a novel feruloyl esterase from Aspergillus oryzae in Pichia pastoris with esterification activity. Journal of Molecular Catalysis B: Enzymatic, 110, 140-146.

ZNAMEROSKI, E. A., CORADETTI, S. T., ROCHE, C. M., TSAI, J. C., IAVARONE, A. T., CATE, J. H. \& GLASS, N. L. 2012. Induction of lignocellulose-degrading enzymes in Neurospora crassa by cellodextrins. Proceedings of the National Academy of Sciences.

Legends to tables and figures

Table 1: Monosaccharide contents in the hemicellulosic
fraction from sugarcane bagasse
Table 2: The percent of phenolic acids of the lignin
fraction associated to hemicellulose from sugarcane
bagasse
Figure 1: The Structure of feruloylated arabinoxylan,
with diferulic bridges cleavage sites for $\alpha-L-$
arabinofuranosidase (full arrow) and feruloyl esterase
(dashed arrow)

